Andrews University

Digital Commons @ Andrews University

Master's Theses

Graduate Research

1959

\title{
A Survey of Work-Education Programs in Seventh-day Adventist Academies
}

Robert A. Tyson

Andrews University

Follow this and additional works at: https://digitalcommons.andrews.edu/theses

Part of the Secondary Education Commons

\section{Recommended Citation}

Tyson, Robert A., "A Survey of Work-Education Programs in Seventh-day Adventist Academies" (1959). Master's Theses. 153.

https://dx.doi.org/10.32597/theses/153

https://digitalcommons.andrews.edu/theses/153

This Thesis is brought to you for free and open access by the Graduate Research at Digital Commons @ Andrews University. It has been accepted for inclusion in Master's Theses by an authorized administrator of Digital Commons@ Andrews University. For more information, please contact repository@andrews.edu. 


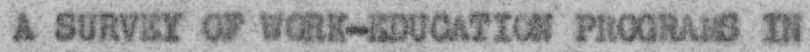

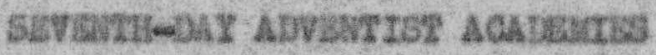

Rabert A. Zyson 
This dissertation, written under the direction of the Chairman of the candidate's Guidance Committee and approved by all members of the Committee, has been presented to and accepted by the faculty of the School of Graduate Studies in partial fulfillment of the requirements for the Master of Arts degree.

Date .... June. 1959 .

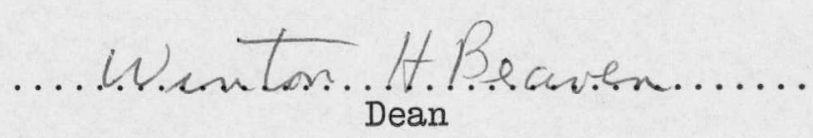

Guidance Committee

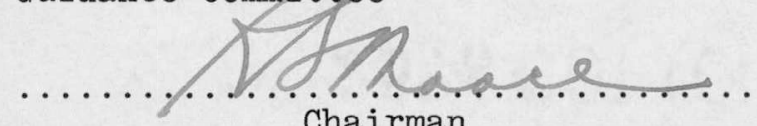
Chairman

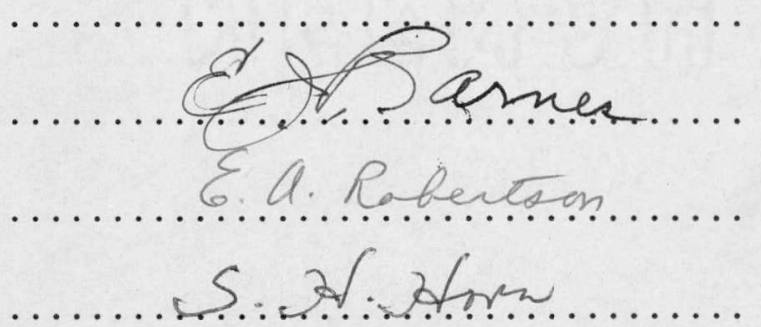




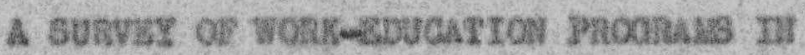

SEVam-aAX ADVLKrYS ACADautes

\section{A Thesle}

Prosented to

the Faculty of Potouse Universtty

Foshangton, D.C.

In Partial fulculnent

of the Regulreanents for the Degroe

Laster of Arte

Departeont of Education

$$
\text { by }
$$

Robart A. $2 y s c a$

June 1959 


\section{whess or commans}

atsprea

Paca

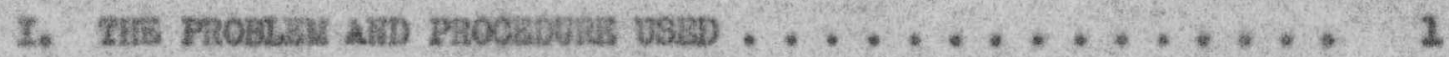

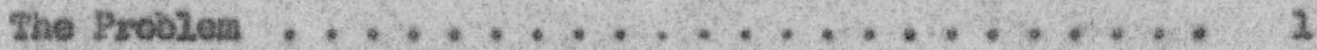
Statemat of the problan ..............., +.. 2

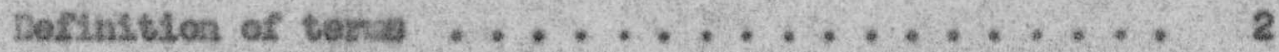

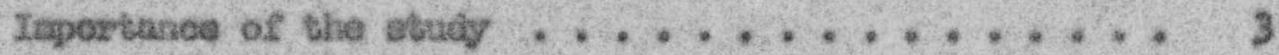

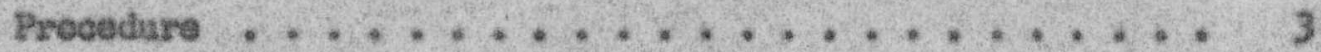

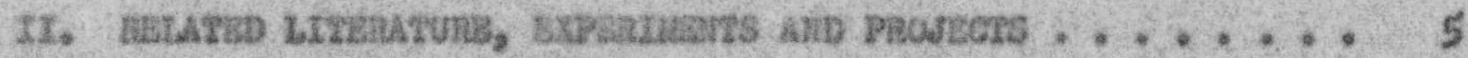

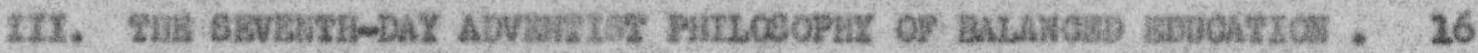

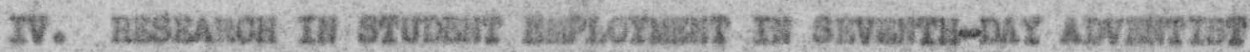

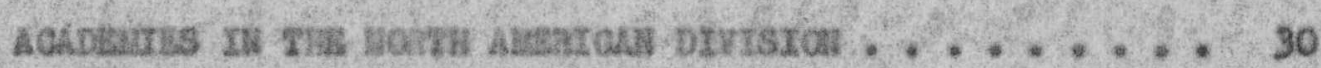

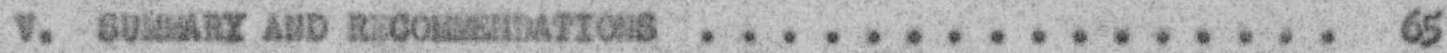

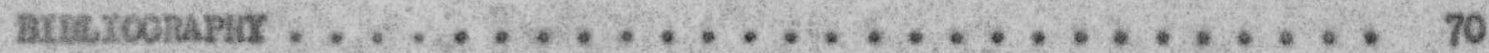

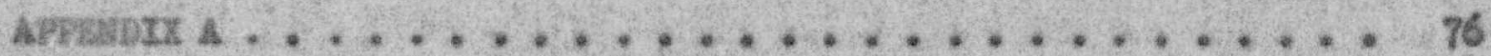

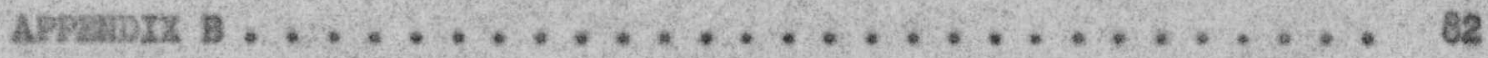

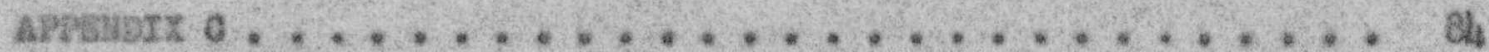




\section{List of p Iourias}

Fouls

PROG

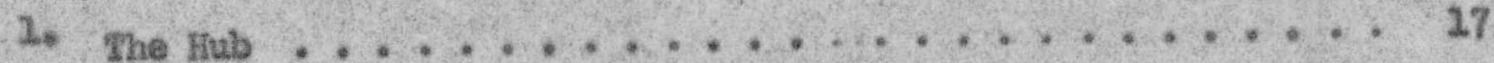

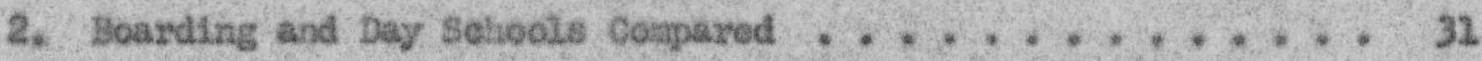

3. Percantage of Vay Barred at Bohoal by Btudants , * * * * * 32

4. Student Enploywent in Moarding and Day Sahoole *... *** * * 33

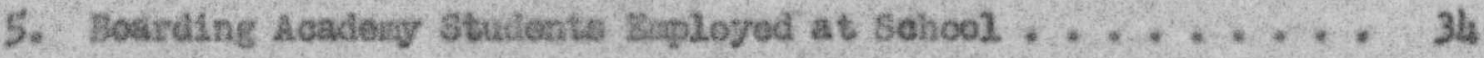

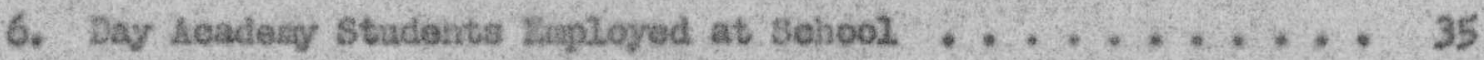

7. Student Induatrios $\ldots \ldots \ldots \ldots \ldots+\ldots \ldots \ldots \ldots$

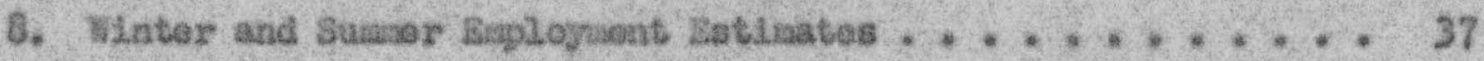

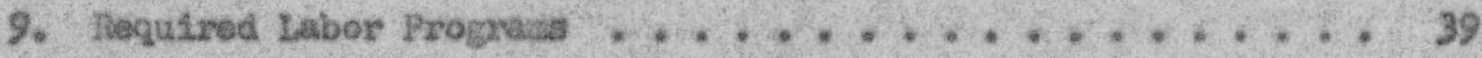

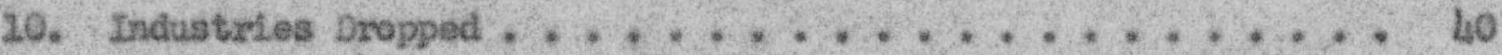

11. Are School Adrinlatratore Batiafled with Thelr Labor

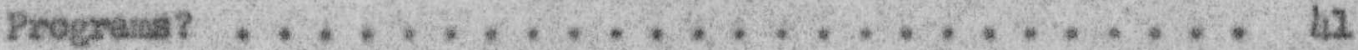

12. Do Acadeny Adninistrators Feed That Thelr Bohools feach

Sevanth-clay Advontlet Btandards In the Work-widy Progran? * 42

23. No Acadery Adatnistrators Feal that There is a Deflutte

Relationship Betwoon No12-Ciugerviesd Progran and Charseter

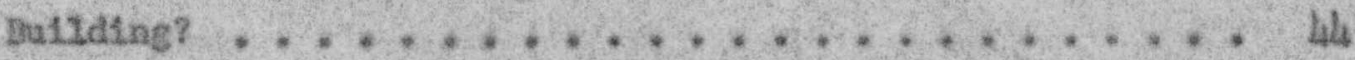

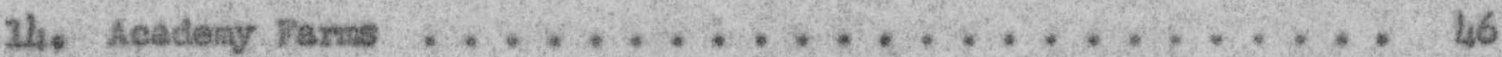

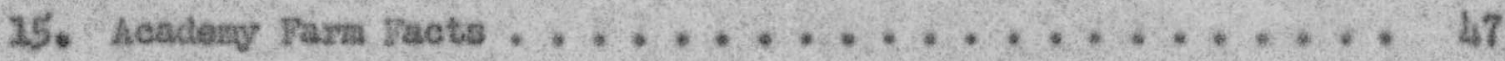

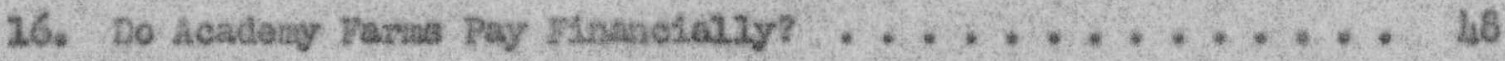

27. "1io You Belleve Ln a Daliool Fark for Bducational Noasone;

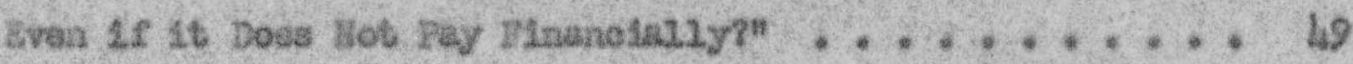


18. Do Seventh-day Adventlat Acedeales offer a Balaneod Eork-

study Progras? ...................... 50

19. Do State Laws Afrect the Acadeay Labor Progran? . . . . * . 52

20. When Are Working Papers Obtainable? ............ 52

22. Tara lachinery..................... 53

22. Power wachinery ................... 5h

23. Acadomtes vith Student Industrial Acoident Insurkance ...... 55

24. Ruaber of Moavtlng Sohools Desiring Hew Industries ...... 56

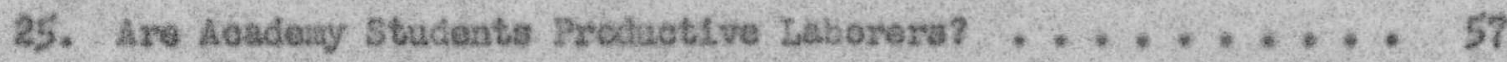

26. Faculty Supervialon of Studeat Labor ............. 50

27. Indoor-Outdoor Replogwent ................. 63

26. Sose of the Character Gualities which Students Dovolop whtle

In a student Labor-study Prorras (rroa liount Vernon, Obio) • 64 
In arder for education to train the total perwonalitys. is is felt that the students w122 be greatly beneflted by plysical, preferably outdoor, work. In the fornatsvo adoleacent years the student shcald Lears hablte of Lndustry, neatnoss, huatlity, end dependablizty. An anz-around charsoter $1 \mathrm{~s}$ best developed by a wholesose attitule land an aetual exporience in produetivo work.

\section{The phonuse}

Statenent of the problen. It is the parpose of this study (I) to derlne elearly the philesopity of physieal labor in the Chrietsan sohooly (2) to tabulate and evaluate the scope of student enployrant In the Seventh-iay Adventiat acadenles Located in the North Anorioan Divietong (3) to discover which Induetries have borme the teate of the and cospetitions (4) to detoriine the nuaber of atudests exployed in such lndustries as w113 relleve norve and eye strain wille eupplying needed exercise; (5) to polnt cub sone of the laws rolating to child labers and (6) to nase sose tyeelfle suggestions whloh ndght cevelep a sleher and botter balanced labor-study progras on the cangsaes of the acadeates. 
Definition of terms. The word "acadeny" as used in this paper designates a Seventh-day Adventist school offering sentor high school work (erades 9-12) only. The report does not cover the 236 internediate acsdentes or Junior acadoules in the Horth Anericen Division Conference of Seventh-day Adventists. The North Aneriean Divialon territory raferred to here covers al1 of the Untted States, ineluding our new states of Alaska and Hawal1, with Bermuda and the Doninion of Cenede. This study is not deeling with student labor in the score of colleges, schools of nuraing, dentietry, and medicine operated by the Seventh-day Adventiat ehureh in North Americe. Student 2abor, in the frane of reforence of this thesis, Is any student employment by which a student earns his or her expenses while attending sehool.

Learaing propor woric habits and attitudes is very important to the prinary and elewentary school child, Nost of these hablts and attitudes aust be learned in the home, unfortunstely, for education is too bookish even on their level. College students, for the nost part, are old eaough to have settled patterns of behavior in respect to worthwhile enployneat. The writes is limiting the research results in this peper to the high school (acadeny) age young person. It is during these years that work-habits and charaeter-traits are fired in the personality. The acederyage students offer a rich fleld of observation for such a study. It is interesting to note that more then 238 of the students in a.1 Seveath-day Advent1st acadeates, boarding and dey schools included, woris $25 \%$ of their way through the secondary sehool. More than $18 \%$ of 


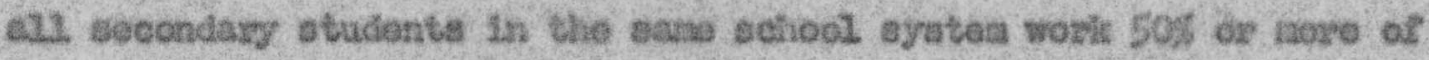
thall way through sohool.

Isportanoe of the study. The hlgh cost of privste sodocts is lnowa to all edueators. The great charaoturwulldthg values obtalnod

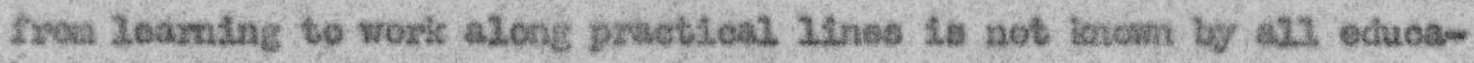
tors, Whother in biaes of vising costs, lnflation, on in tines of 14atled 2abor opportunitles, deprosalon, thore w111 eontinue to be a Couand on the part of studentes parentr, and boards for renanerative student engloysant. The sarly age at which students are now roachlns acadery level, cortain state child Labor laws, and the Mth sonthy

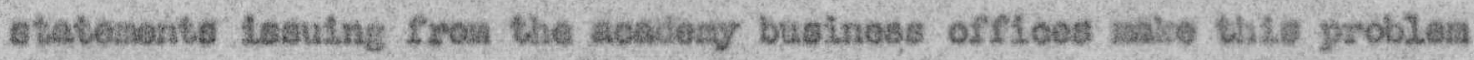

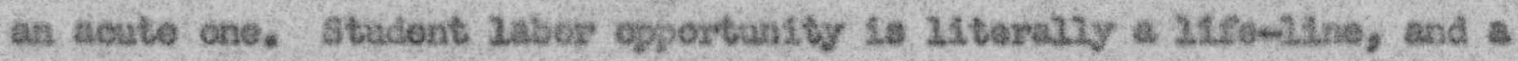
Blessing, to asany etudonts and Eobocls.

As Adventiet saheol enrollinonts continue to rleo La barrosy with the Increase in chureh and cocterence nauberships, the coet of finaneing the schoole will continue to grow. It appears to be of the atwoet 1 hoprtence to anawer the guestlons what are the sceceasful Indubirleb which have offered atudent 2abor in the Seventh-day Advanliet acadentes of the North Aneriean Division between the years of 1949 and 1956? BLple Language and preotical. 132ustrattons w131 be enployed in an endadvor to andwer this questlon.

\section{RTOOSDURE}

A questlomalre was cent to the prinolpula of the esventy-liwe

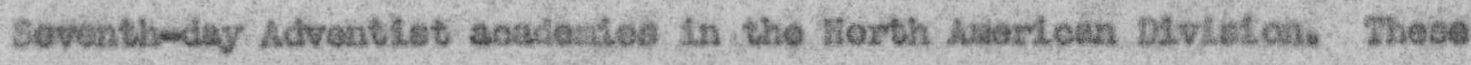


basy sen sont back kind and helprul roplles, diving faots and cosp-

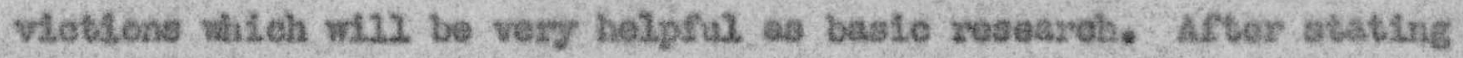
the problen, a survey of the Literature in this area, a batel biatory of woxk as $1 t$ relates to eduestion, erpeetally in the Intied Btates, wi1 bo given.

The wrthings of the Mble, and of Ialen 0 . thithe and othor educstore, are quoted to glve the basie for the phusopophy of education which sees grest value in orgentsed phyeloal labos in connectlon with the stridy of books. ${ }^{2}$

Gince 2esderohip ts tho key and comerstone to doing scouthing about this felt noed in edtacation, brief blographles, charts, craphs, tables, and rocosaendatione for futare action are emploged.

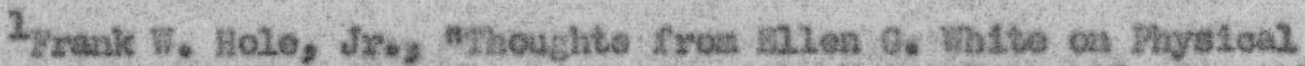

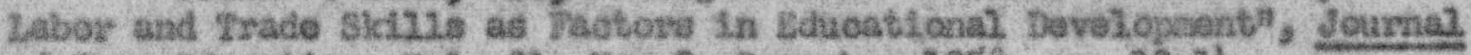

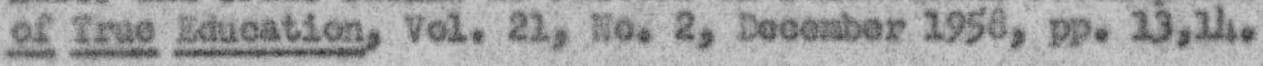




\section{GHATBR II}

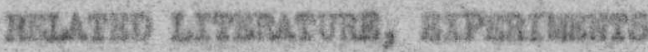

\section{Airs Phow Bong}

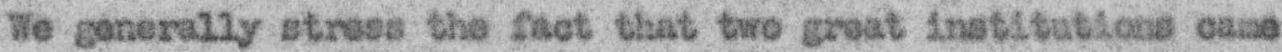

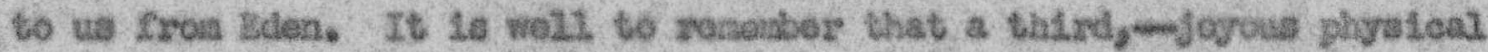

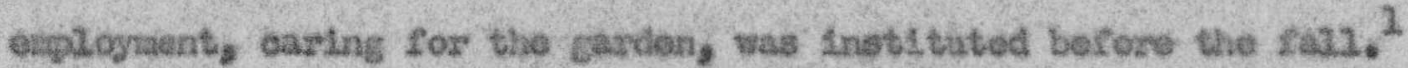

Blomantal dorinitions of "work" nitht ronge fros matter in aotian os force in aothon to purposeful Intelligence striving for a wortininile attadnuent.

Tho anoleat Iicyptians suroly organized great sorta projects. The code of Eawnarabl of the 206h Contury 8. O. rogulated that an artiban was to adopt a bog as a son and to teach hia that hals art rea not uneassons?

A21 of the natlons of the sactont ortent develoged tha aprour Wee tyatein of training the young in trades. By fay the largest portion

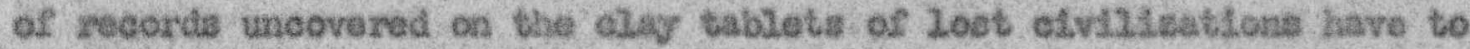

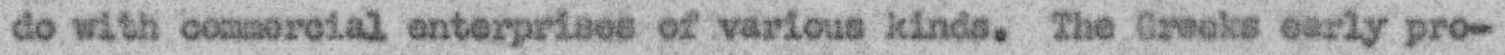

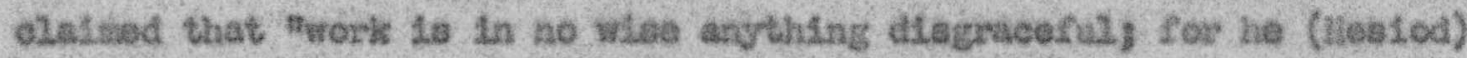
ealied work what is done wall and venfuly. ? $^{3}$

\section{0en. $2: 25$}

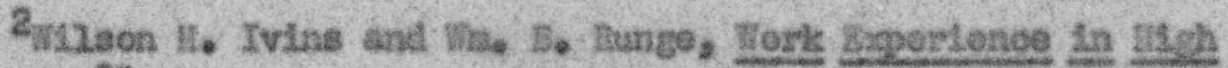
Seinool, D. 23.

3 pand Schreatcer, Nork and Mistory, p. 25. 
Fouv - sundred yoars betore Oreese reached 1ts Colden Age the Hebrows had a aysten of edueatlon which was a practlcal blending of work and atudy, These sehodls were known se the Schools of the Prophets. Dilshe is reaswbered as the groat wan of fath and practioal works in education. 4

The balaneed, woric-studv, phystaal-splritual progras of the Sohools of tho Hrophote ie hore described.

The physical as wall as the rell clous training practiced In the sehools of the Robrows nay be profltably stisdled. * * .

And now, as in the daye of Ioruel, every youth should be Instruco ted In the duthes of prection 112e, Lech should acgulre a knowledge of sowa branch of manual. Labor, by whloh, if need bo he nay obtain a Livelthood. Thie is essontial, not oniy as a safoguard agatnst the viciseitudes of 14id, but froe 1ts bearlng upen physteal, nonval, and aoral dovelogment. Even if it wore certaln shat one vould

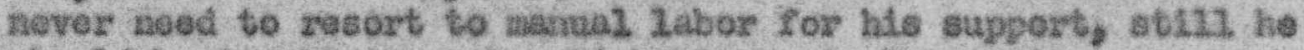
ahould be taught to work. WIthout phystah exterolse; no one can have a sound coneultution and vigorous beslthy and the dLeotpline of wellmogulated laboy id no loss essential to the securlng of a strong and aetive alnd and o noble character.

Svery studant sheuld drvote a portion of each day to sobive labor. Thus habtts of Lndustry would be formad, and a splrit of eals-rellance eneourbiged, while the youth would bo shlalded fron aery evil and degrading pructices that are so often the result of 1dleness. And this 45 ali in leseping with the prinary objeot of educatiou, for in encouraging aotivity, diligenes, and purity, we are condns into hamony with the Creator.'

The puplis of these schoole subtalned thenselves by thels own

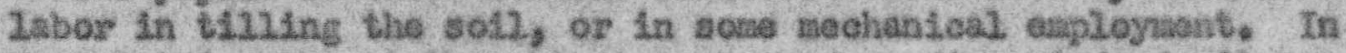
Israel this was not thought strange or degradings indeeci, 11 was regarded as a sin to allow childron to grow up in Ignoranos of

\section{II KIngs 6,2dis "the Contributsion of the Schools of the Prophete,}

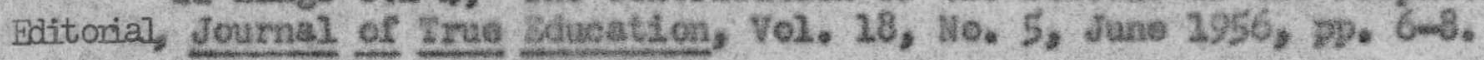

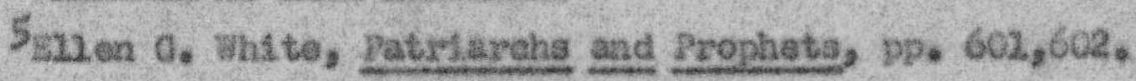


useful Lebor. Bvery youth, whether his parents were rich or poor, was baught sone trade. Bren though he was to be edusated for holy offlee, a knowledge of practieal life was regarded as essential to the greatest usafulness, Many also of the teachers supported thenselves by menuel labor.6

In God's plan for Israel, every femliy had a howe on the land, with sufflelent ground for t131ing. Thus wero provided both the reans and the incentive for a useful, industrious, and self-supporting 11fe. And no devising of men has ever Improved upon that plan. To the world's departure fron it is owing, to a large degree, the poverty and iretchedness that exist today.

By the Iaraelites, Industrial training was regarded as a duty. Bvary father was required to see thet his sons learned sone useful irade. The greatest mon of Iareel were trained to industrial. purguits. A knowledge of the duties perteining to housevifery was constdered essentlal for every womans and aictil in these duties was regerded as an honor to wonen of the highest station.

Various industries were taught in the schools of the prophets, and many of the atudents eustained themelves by mamual labor.?

Apprenticeship renained the center of prectiesl education for hundreds of gears. It was widely practiced in the Anerican Colontal Age. It is st111 follored quite Lergely in Burope. Aneriean edveation, sed to say, both in the publie sehools and In Adventist schools has not supplied arything adeguately to teke 1ts place. With the Renalssence and the Refornation education vent elnssical, getting lar off center as far as prectical training is concerned. Bven the poor ere tralned as thoagh they were the "ariatocracy" who never would need to 2 eam to work. Rducatlonally, the words of Ceorge Mann Rlchardson, spealsing at the comencement of Leland Stmaford Untversity in the yoar 1901

Grien 0. White, Education, po 47.

$7_{\text {mulen }}$. White, Counsels to Teachers, pp. $275,276$. 
foli on deaf ears. He then sald, "Mothing that s.s worth laving is to be had without workt " $^{3}$

Shortly before this thare began to rise up in the provilence of God a few brave plonears who sas that eduoation was falling to educste a balanced produet. Azong thea werv lastha Berry, B2len 6. White,

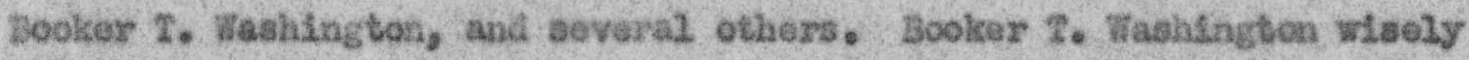
began to proclain the "gospel of hard work with the hands as a part of useful ectucation."n9 He also sald, "Where has been alnost no thought of connecting the educated brain with the educated hand, a10 Ho Rurther abserved, "hiere is an indeseribable sonething about work with the hands that tends to develop a stidantls innd, " ${ }^{12}$ His large coneept also proolained, "bore hand tratritns, without thorough morul, rolsgious, and wental education, eounte for very 1ittie. The hands, tbe head, and the hoset togehher should be se correluted that one any be aade to help the othere. ${ }^{12}$ Though he net opposition froa all sides at Ifrat, he 1ived to see his plan widely acclatzod, Washlngton aought to ralse one shee abovs the dovel of alavery. It 10 the work of true edueation to 11 ft all racas above thatr binding traditions.

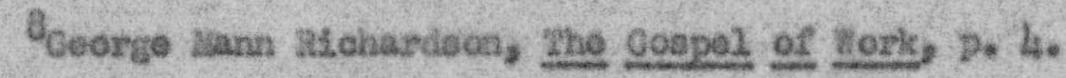

9ookor T. Washington, Norkins W1th The Eands, p. 103. 10 1bid.s p. 137.

11 mbid., p. 50

$12_{\text {IDid:, Introduction, D. II }}$ 
Willian Lorris of Inglend strongly 2 anented the Laroads of mass protuetion and the Indistrial rovolution upon the inner satlafaction and gonuine self-oxpresalon in the art of rumiture sakine, te stated, of society which has no joy in 1te work w111 ultinately collapeo, "23 Perhops this explatns in a Deasure the restlessness, delinguenay, druakenness, and oriue of our ace.

Disceming educators fron the world's great schools sar that the yeuth were weolving an unbelanced tralning. F, 0, Nlohols of tarvard beoane convLnced betweon 2895 and 1900 that work and etudy should be conbined. He was problioally tho father of the work-esperlence nowesent which is now natlon-wide, though it raaches very fert, Guviles A, Prosser

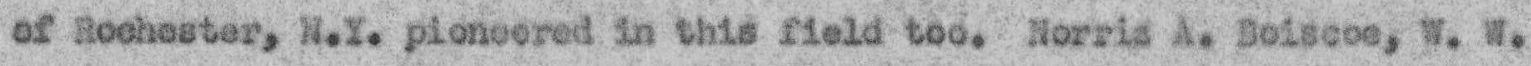
Chartore and others helpod to launch a progras of rork in the comaunity for eredit while doing work oz aoddonte lines. One of the modorn outgrowthe are the ahops in ncarly all sohools and the vooationel gutdance prograsa, 24

Lueinda wyman Prince in 1905 launched a progran wilch gainod wide acceptance for trainiug girle for salea work. Out of th has gromn the diatributive education novianent. 25

Herran Schneider, who worked his entire way through Lehigh University, lawnched what 18 now kncwn as eooperstive educellon. In

13 Douglas $\nabla$. Stcere, nogks and Contang2atLon, F. 63.

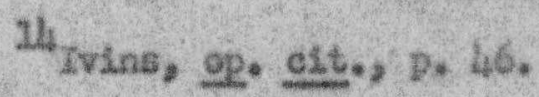
15.vins, ge. aiter, p. L3. 
2906 he becase Dean of Inglnesring at Cineinnati University. Todey more then sixty of America's greatest Instituelons including Wassachusetts Inst1tute of Technology, $\nabla 1 r g i n i e$ Polytechnie Institute, and others of 15ke reputation send their students out to 1 earn and earn as they study. 16 The Martin Alreraft Company in Baltinore employs several student engineers. When the M. Itudson beeane president of Blackburn College in Car24nVille, IH11nols, in 2912, the school was both poor and saell. He adopted a studeat-employment, self-contained unit plan. Poos students willing to work, eane in. They found eaployment on the farns, in dalry projects, In paint shops, in carpenter work, in the heating plant, and in seeretarial works, and so Sorth. Ho did In the Morthwest what Laurence C. Jones wes doing for the colored at the PIney Woods Country Life Sehool in Misslselppl. Dr. Jones says of h1s sohools nos the present enrollnent of 500 students (1956) less than 10 per cent are able to pay any tuitlon at all. It Is a rule of the school that evory stadent aust do some work, and the major1ty are sul1 works students. $\mathrm{m27}$

Antloch College, Yellow Springs, Ohlo, is widely known for 1 ts student-worle program. Horace Mana was its flrst president. When Arthur B. Morgan becane president in 1920 he launched the vigorous work-study progran. Its graduates are widely know for their conpotence and extenatwe knowledge ${ }^{28}$

16 Henry H. Armsby, Cooperative Education in the United States, Do 24. 27 Beth Dey, The Littze Profeseor of Plney Woods, po 282. 28 Ivins, op. c1t., pp. 55, 56. 
The centar of Llorgante Ldea was to "prosote the devolopaent, in proportion, of every elenent of personallty." Antlooh Callege requires for the A, B, or B, B, Degree ninoty or nore cooperutive erodits in what Le called thelr Studyolusework Maz. This work nag be on os off caspas or cutside the V.S.A. 19

Bducators who had Anerlea's best Intereste at heset porenaded

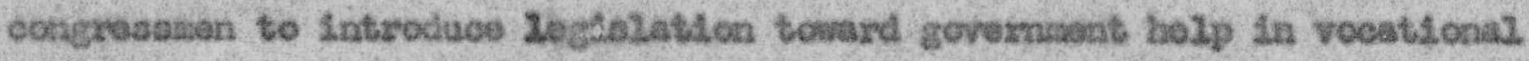
equiprent in the schools. On Febraary 23, 1927 Frealient E13eon elgred the Stathollughes Act whtoh was a cranth-1n-ald progran. Botwoen 2933 and 2942 the cce gave praelical orgloysant to any uature but otherwise unemploged young nea. The $\mathrm{mzh}$ osfored work opportunilies to both seres, and in 1937 reached 1 ts poak with 191,000 youth exployed, The coorge-

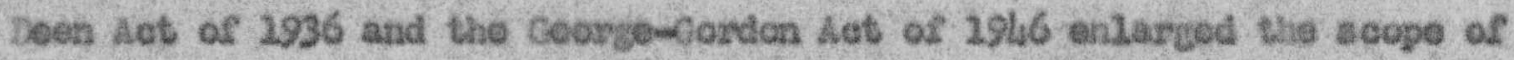
govornaent ald to vocational eduestion. It was only a satertaliatio

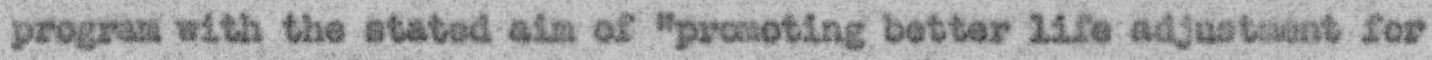

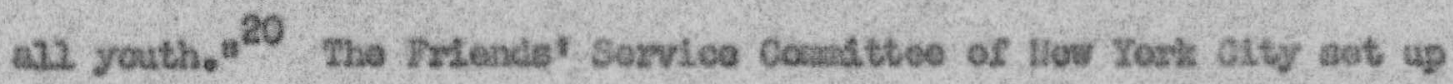
Junior Achlevenast, Ine. to offer a riehar variety of Mife astuation approsohies. 21

Aftor severul years of experthent with the wortimexperlence progrean in the achocis it was fond that nost edicatore proforred to affer

\author{
19 Antsoch callere Burotin, June 1957. \\ 20 Ivins, ge, altes Bp. 31-39. \\ 21.
}


thise to youth of sixteen yoars of age and up. FuLlsdelphia ard Minneagolls adistted then at the aces of fourtean and fiftecn, The edventors gald that this woric-expenlence progran would be good for all nomal youth. Too often these to besefit fron it were the unadjubted probles chiseiren. 22

The five basie objeotives of cooperative edication, witidh is Jargely a yrogras of tratuling engineers, are :

1. To Lingart firethiand knowledge of ongineerling.

2. To gdve an underotanding of the probleas tivolved.

3. To teat the aptitude of the student for detasis.

4. To adjust to the work of engtneering.

5. To train and apot those who have edmintstritive absuttea, 23

The seven basio assuiptions of the general work experience prograss are:

2. Ioxic 10 a psychologleal eseential in the learning process and in the developmant of personality.

2. Work experience helps to Lingrove the total soicol progran in providing ganeral adjustiaent and balance.

3. The Inadectuagy of the urban how denands worit expertence.

4. Nork has theropertie values in holping to hall the hurts of $21 \mathrm{fe}$.

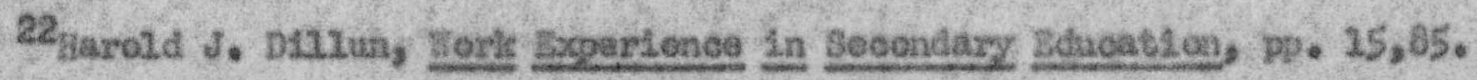

${ }^{23}$ Henry H. Amaby, "Cooperative sducation in the Inited States," (2955) p. 3. (Adapted). 
5. Caly through exgerience in the formative yeare can congetent woricers be proluoed who will ald soctety,

6. Work expertence w131 have tranefer values to any future voeallonal cholce.

7. Work experience has definite transfor values in dharaoter developnent, 24

The general values to education of work expertence arvt

1. It pernale individualiaation of instruetlon.

2. It buthds our doancracy by producing sootelly congotent and reoponsible ellizens.

3. It offors a broad lmomledge and offers opyortunity for definite mastsry of sicule.

4. Work experlence de-erphasises the deadentng effeots of forwaliastion in ediestion.

5. Work integrates the student with real 11 fe experiences. 25

Work experlesce glves the following valugs to the prospective workers:

1. Relationohips wtth the eaployar are learned,

2. Attitudes toward worli are forned.

3. Fratts such as rogularity, dopendabi11ty, tuot, adaptablisty, polse, ete. are developed.

241vina, g2. este, Do. 74-79. (Adapted).

25 mid., pp. 54,55 . (Adayted). 
Lo Cooporation 18 found to be essentiel.

5. Vocational cholee hes real meaning.

6. Voeational ski12 is tested and porfected.

7. Self-respect and attitudes of service and usefuiness to aoclety are fostered.

8. Job Intelugence and Inegination are given free retga.

9. Motivation for learning is conerete.

10. A sense of values, 1 ncome, and budget are rade reel1st1.e.26

The Union of Sovlet Soelalist Repriblics in 1958 announeed that students between grede school and high school would be exployed brleny olther in factorles or farms to gain practleal. experience.

Dr. Norence Strateneyor, well-known teacher of teechers from Colunbia Univoratty, was asked her opinion on a work progran in connection with the school. She roplled with conv1etion, "I, would have works experience wl1 the way through, even in college, "27

A dozen Seventh-day IdventLst colleges and seventy-rive acedentes aro endeavoring to find a blend of phyrteal zabor and acadento study. Marthe Berry Sehool in Georgie and Berea College in Kentuoly are SollowIng a woris-study progrea.28 Bezes College offers students work in

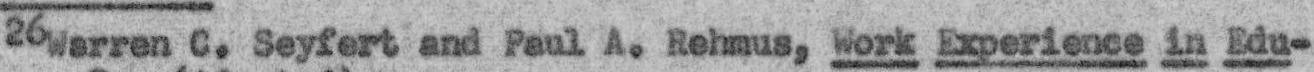
eation, D. ?. (Adapted).

27Dr. Norence Strateneyes sade this statenent in the Seventh-day Advent1st Eestern Study Conference in Education, Washington, D. Co, January, 1959, in response to a question by Dalton Baldwin, Superintendent of Schools, Sest Ponneylvanla Conferenee of Seventh-day Advontists, Reading, Ponn. 20 Herriett T. Kane, Miracle in the Mountains. Berea College Buz20tin, $1958-59$, p. 7 
aisty-four departmant3. Bach student must work tea hours a week. They employ a dean of labor. Nary Seventh-day Advent1st achools could profit by thotr exanple. 
CHAPFER IIT

\section{THE SEVEUTH-DAX ADVLWTST PHTLOSOPHX OR}

BALAMCED WDUCAFION

Worls of the voricer, is the center of the Internationel ConsunistCepltalist controverey as well as many of the problems faelng the modern world. Work, or practical educatlon, is the pivotal point around shich en edeguate philosophy of true edication revolvese (Bee Blgure 1, p. 17.) ${ }^{2}$

The nature of man is in revolt ageingt his gadgots, earpeted. Roors, and autometic heat. Durlng $1958,90,000$ elty-alek people eamped In tents at mik leck State Park in Maryland, 2 Several hundred thoueands cemped In the great parks of the far west. Living has been teiken out of Iife at home, and the schools for the nost part are deader then the hone. Aleohol, television, over oesting, eberrent sexual. experlenees with thoir attendant diseases of body and nind are the result.

An oceastonal farily tenting in the woodland is only a partial anตwer. 3 What is needed is a revolution in concept of the hore and school. The echool shovid be praeticel and eharacterocentered. Counsel. cens years ago to the Seventheday Adventist church.

Our Ideas of edueation taice too narrow and too low a range. There 1.s nesd of a brosder seope, a highes alth. True education means more

13. H. Oldhan, Woris In Modern SoeLety, p. 19.

2statenent of Eugene B. Barnes, Park Super1ntendent to the writer. 3ileherd C. Cabot, What Yen LIve By, p. 29. 


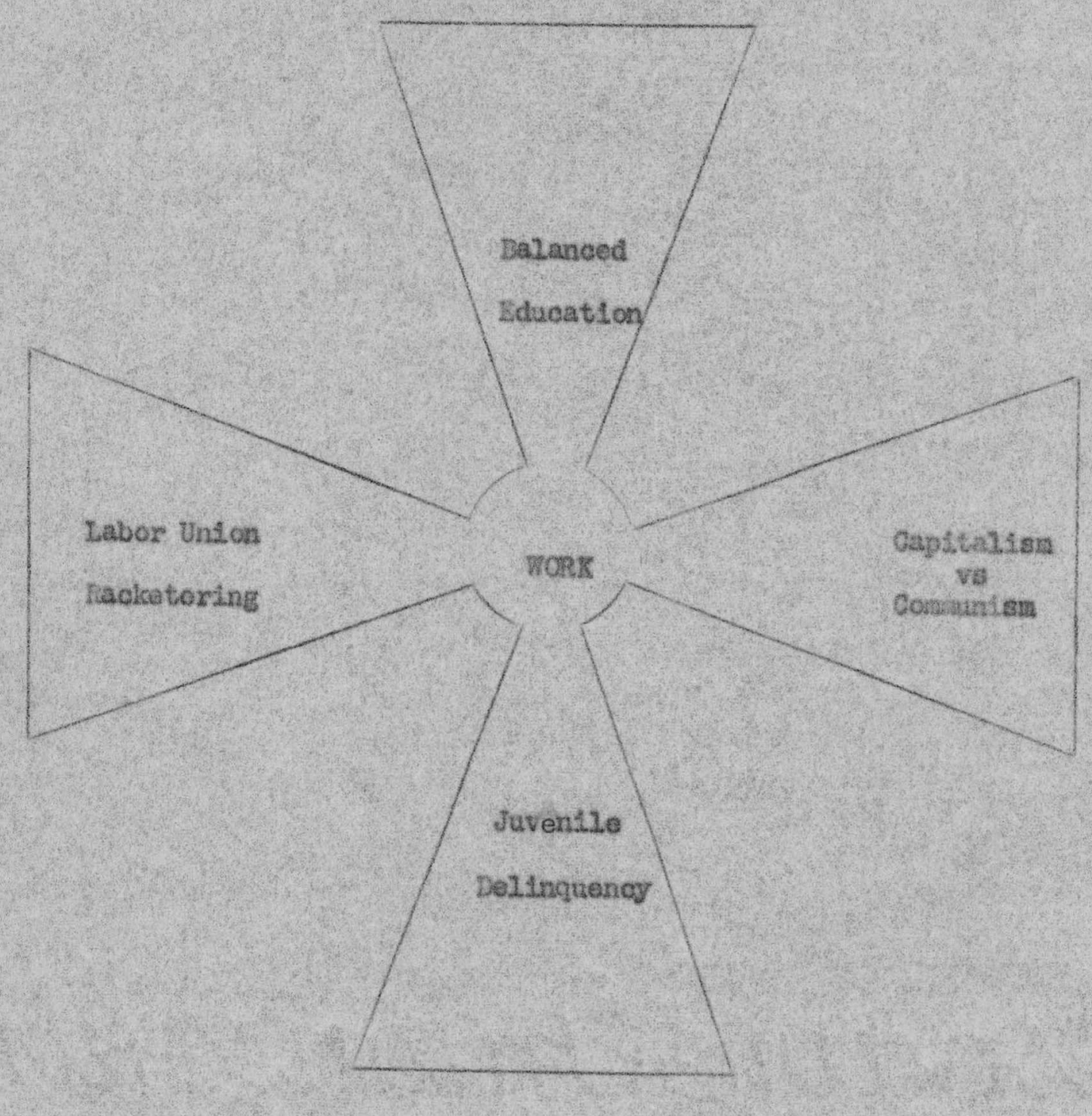

probis $\mathrm{I}$

TI2 หมล 
than the purvual of a certatin course of study. . . I It ts the hartonilous, developiant of the pivsical, the mentas, and the splrituel powere. 4

Three generatione of Desvers becone sterlie when brod in captlvity. ${ }^{5}$ Poupey's aristooratie troope, born in palioes and reared in villas by slaves, wore no satch for Cassarte sona of the soll. floyal fandlies always maintain their sountry estates. The early Acventists accosplished marvols for euch a wail band, They soved out, araed with the spirity they Ifved and educated in the simple, rustic, rursl atsoephere of the ploneer. 6

Men Jike to eatch fleh with fight in then. They Love a oballenge. IItness how thoy w121. give for and go to a war. The ghaulenge of eln and moting $1 \mathrm{t}$ in the tine-tested Christian sohool is egual to the beet talent and wortly of the deopest devotlon. Researohers are needod with the solfLese Cevotion of Ceorge Faahington Carver and echeational wagnates with the adaintatrative acunen of Beary Jord. "Both of then belleved in the benefit of work. Ford with his sulitions had never Learred to Fraste tiret, -nelther had Carvor, ${ }^{7}$ Advantiete have alrays worked wi th a conviotion that tive $4 s$ about to zun out.

Westen Civilisation Lis rothing for laok of the culture of the honest hand. The educated usid wi thout a task at hend oreates visened
4.jien G. white, Zducutsion, D. 23.
5.m11 s. Wers, A Deaver's Story, p. 10.
6. .. Spalding, Goptaing of the Eost, pp. 421-453.

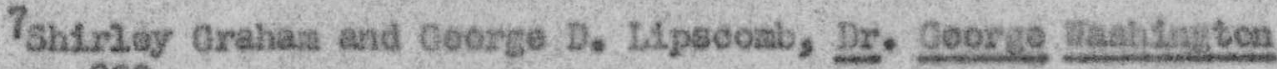
Carver, D. 209. 
norrtal misers. IItharam, they have no practical seasage to glve to the wor2d. This aristooratie LapraotleabListy sters fron a laek of practieal. education frow the first gate up. Fork of any kind 1 s thought by too. zary to be degrading.

Booler \%. Hashington sald wisely:

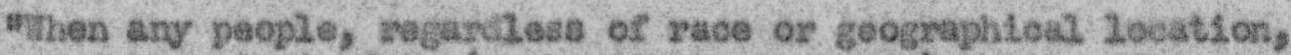
have not been tralned to (work wlth their hands) hablts of indusiry, have not been givea old11 of hand in youth, and tescht to leve labor, a direct result is the broeding of a worthless lilie class, which eponds a great deal of 2 th the in trying to 21 ve by its wits, ${ }^{8}$

"Lot everyone sweop in front of his ow houve end the whele street wish be clean. "t?

Is there one thing, above eal othors, whleh, If lnculeatod Into the basie progran of Christlan education, w131 produce students of eharaoter prepazed to render acceptable service?

There let Let us seareh for it.

Purity is essential to charaster. It is character. It eannet be sttained without propor physloal exerelse.

The student who with linited the and means is strugeding to gatn an education should roalize that tine spent in physleal exerolso is not lost, ite who continually pores over his boolss will find, after \& tive, that the alrd has Lost 1 te freshness. Those who glve proper attention to plysical development will aako greater acvancement in literary lines than they would if thair entiro tiae wore devoted to study.

By pursuing one line of thodght exclusively, the mind often becoses unbalanced. But every faculty may be safoly exterolaed if the

Booker R, Washington, Torking W14h The Hands, p. 2no,

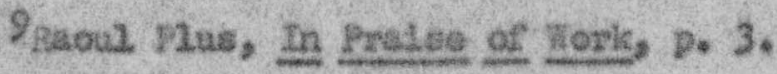


nental and physieal powers are equally taxed, and the subjects of thought are varted.

Physical inaotion lestens not only nontal but norul power. The bruin nerves that connect with the whole systen are the nodlua

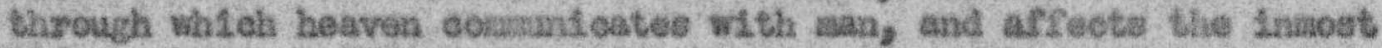
14fe. Whatever hindors the circulation of the electric current in the nervous aystea, thue weakening the vital penors and leesening. mental susceptibility, makea $1 t$ nowe difficult to arouse the moral nature.

Again, excossive study, by lnereasing the now of blood to the brath, createo aorbld escoltability that tands to lessen the power of seif-oontrol, and too often gives sway to Lypules or capriee. Thue the door le opesed to Lmpurity. The misuse or nerruce of the physieal powers is largely responsible for the tide of corruption that is overspreading the world. Tride, fuinese of bresd, and abusdance of idleness, 1 are as deadly foes to humas progress in this generation as when they lod to the destruotion of Sodos.

Teachers should understand these things, and should lnstruet theix pupils in these 2ines. Feach tha students that right $21 v i n g$ doponde on right thinifigs, and that plysioal activity is esaential to parlty of thought. nI0

Nork is necassary to hasith and sorality even for the well-tomio.

The first and constent care of parents should be to soe that thelr chlidron have fire constitutlors, that they may be sound sen and wosen. It is imponsible to attain this object without physical. exeroise.

For theis ow physteal heal th and woral good, ehlldren should be taught to work, even if there te no necebality bo far as want 10 coneerned. If they would have pure and virtusous obaracters, they mast have the dlacipline of well-regulatad labor; which wA3l bring into exterolse all the masoles. The aatisfaction that alihdren will have In being useful, and in denylng thenselvas to help othore, w1.21 bo the most heal thind pleasure they ovor enjoyed. 12

The sohool should etout2y wajatain the dignity of jabor. It should encoursge the youth to enjoy plysical Labor. Pregtieal education should atress labor rather than ganes,

$$
\begin{aligned}
& 10 \text { sues 0. White, Bduation, pp. 203,209. } \\
& \text { 11.ulen 0. White, chlld culdance, p. } 342 .
\end{aligned}
$$


Notwithstanding all that has been Bald and written rogarding the dignity of manual Iabors, the foeling prevalls that it is degruding. Popular opinton has, in rary calnde, changed the order of things, and men have cone to think that it is not 11 thing for a man who woris with hie hands to lahe his plabe astong gentlenen, lan woxk hard to obtain sucuey; and having gelned wealth, they supgose that thetr noney w1.11 aake theliz eons gentlenen. But masy such fal1 to train thels sons as they themelves ware tratned, to hard, veoful labor. Thelr sons spend the soner anzed by the labor of olhers, w1thout understanding 2 to valres. Inas they atsuse a talent that the Lord designed shouid acoonglish moh good.

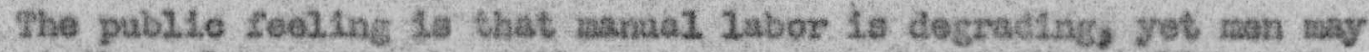
exert themselves as atch as they choose at erleket, baseball, or in puglilstlo conteato, wlthout belng regarded ss degraded, 3atan 18 delighted when he soes human belrge using thele plysieal and sental powers in that which does not eduasto, which is not ueorul, which dose not help then to be a blesslng to those who noed thetr holp. Wh1le the youth are becontan expert in gasias that ese of no real value to therselves or to ochors, Batan is playlni the gane of 14re for thelr souls; taking from then the talents thot Cod has given then, and plaaing in thelr stead his own evil atbributes. It is

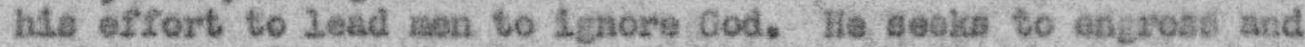
absorb the ulnd so earipletely that cod w11 2 ind no place in the thoughts. Re doss not wi.jis poogle to have a knowdedge of thedr Waker, and he is wall pleabed is he oan set in operstion garies and theatrleal perfornandes Uhat w121 so egpfuse the senees of the youth that God and hosven w132. Le fortotion. 12

What are the baste pritulples of lavorine outdoor phyalcal ewer-

atbe or practloal vork owor even Innocent gasas?

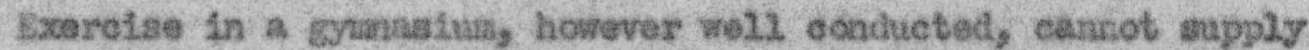
the plece of recreatica $12 n$ the open elf, and for this out schools should afford botter op ontunity:

I. do not ocriem the steple axercise of plaving bally but this, evan in 1 ts simpliel $y$, why be overdone.

I shrink alwayo froc the alnost sure result which follows in the trake of theoe sumenaniss. It leads to an outlay of maans that should be expended in bringing the $14 \mathrm{ght}$ of truth to sould that are perishing

12

Blen G. White, Gounsels to Teacheire, Mp. 273,274 , 
out of Christ. The anteseacris and exponditures of noane for selfe pleasing, which load on atep by step to self-eloftifying, and the educating in these gares for pleaeure produce a $20 v e$ and pession for buch things that 1 s not favorable to the porfection of Cbriatias cheracter.

VIgorous exarolse the pup11s auat have. Fow avile aro thore to be dreaded then indolence and atnlessness. Fot the tendency of nost athlotie sports is a eabjoct of andere thought to those who have ab heart the woll-belng of the youth. Teachers are troubled as they ounstider the Influesce of these sports both on the abadent's progress in school and on his anoceas in afterdife. The gangs that ocoupy so wach of his line are diverting the alnd fros atudy. They are not helping to prepare the youth for practical, earnast work in 21fe. Their lnkuance coos not tend toward refinenent, gonetosity, or real aanilness.

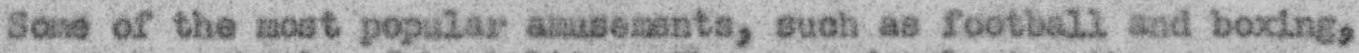
have becoise schcols of brutialsty. They ars developtne the same charuetertetios as did the gases of anolent kosat. The Love of doninatios, the price in naze brute force, the reckless dismegnar of 11fe, sre axerting apen the youth a power to dewornilso that is appalling.

Other athletlo ganes, though not so brutalizine, wis scarcely less objectlonable beosuse of the excess to whleh they ars camled. They otlinulate the love of pleasure and excltencht, whe fostering a distaste for useful Labor, a dispostifon to shui prastcal dutles and responsibilities. They terat to destroy a relleh for IIfe's Eober roallties and tis tranguli. enjoysents. Thus the door is quonsd to disslpation and lawiessness with thete terribie roenlts. 13

Io bulld charactor the study of books is to be eonblned with usem

Sul namual 2 abor.

Let the study of books be combined with userul nanual 2abor, and by fathel endeavor, watchfulness, snd prayer sooux the wiecles that 19 fron abowe. This $w 171$ glve you an all-mound eduostlon. Thus you nay riee in charactor's sad gain en influence over other ninds, enabling you to $2 \mathrm{ead}$ them $3 \mathrm{~s}$ the path of uprightnoss and holiness. 14

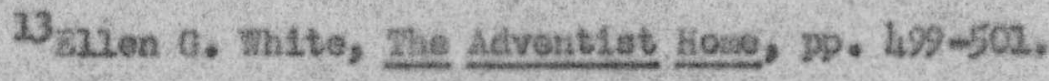

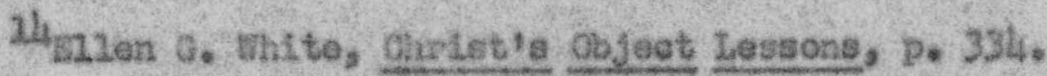


Jeaus 18 our exarplo in rinding purity by devotion to cosseas

manual tasks.

The parents of Jesus were poor, and dependent upon thetr dally to11. He was fauliser with poverty, self-dental, and privatlos.

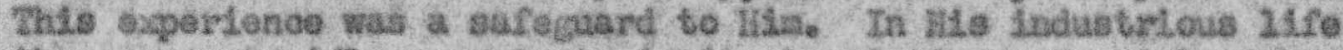
there were no idle sosents to invite temptation, to afsless bours opened the way for corrupting assoolations. So far as possible, Ho closed the door to the tempter. Selther gain nor plessure, agplause nor cencuro, could Induce lilan to consent to a wrone aot. II0 was wdse to discem evil, and strong to resiet $1 t^{2}{ }^{25}$

Woriling in the soll and in the forest propares the alnd to grasp

the ereat toachings of the flort.

Foricling the eo12 is one of the best kinde of exployasnt, ealilng the wusoles Into action and rovting the aind. Strily in actioultural

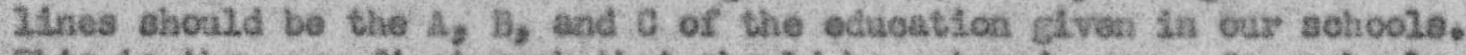
This is the very firot work that should be entered agona Our sohools shousd not depend upon inported produce, for graln and vogetables, and the fruits so esonellal to hoalth. Gar youth neod as education In folling treas and tluling the soli as mell ss in literary 2 inos. DLfrerent teschere should be appointed to overses a nuaber of atudents in thoir work, and ahould wowk with thes, Thus the teathers thenselves w111. laam to carry responsibilities as burdes-bearoro. Fropor utudents also shousd in this way be eduostod to besr responelbilities, and to be Inborars togethor with the teaohers. A.M. should counsel togethoy as to the vory best nothode of axrrying on the work. 16

Hanual labor, proger2y supervised and Lntolligontly done 1 eads

to habits of accuracy and thorouginess.

Cne ereat reason why pixysical toll is looked down on to the sliposlod, unthinking way in whiloh it 18 so often perforwed. It is dene from necesalty, not fros cholce. The workter puts no heart into it, and he nelther preserves seli-respect nor wins the respeot of others. lanual training ahould correet this error. It should develep habite

15alea 0. White, Dealro of Ages, D. 72 .

16 wiven G. White, Iestinontes to the church, val. 6, Dp. 179,280 . 
of accuracy and thoroughess, Pupils should leam tact and systeas; they should learn to scononlse tine, and to make every move count. They should not only be taught the best methods, but be lniplred with ambition constantiy to inprove. Let it be thely ala to rake their work as nesr2y porfect as hunan brains and kands oan aske $1 t_{0}{ }^{27}$

The science of dolng well a humble task roveals oheracter.

There is seience in the humblest kind of work, and 1.1 all would thus regard 1t, they would see noblzlty in 1abor. Hoart and soul. are to be put into work of any kind, then there s.e cheerfulneas and effiolency. In agrioultural or mechanlenl oceupoticns ten nay EIve evidence to God that they appreciate His gift in the pinysioal powers, and the matal faculties as well. Lat the educated ability be enployed in devising inproved mothods of work. This la what the Lord wants. There 18 honor in any clase of work that 18 essential. to be done. Let the $2 a w$ of cod be made the standard of action, and it ennobles and sanotiries all 2Bbor. Fafthfulness in the diem charge of every duty mkes the work noble, and reveals a charaoter that dod oan approve. 10

\section{Dat2y 3 abor brings health and teaches self rellance.}

The healthful exerolse of the whole belng w1il give an edueation that 18 broad and eoaprehenes.ve, Every stadent should devote a portion of each day to aotive labor. Thus babits of Industry wi12 be foried and a spirit of self-rellance encouraged, while the youth will be shielded froa many evil and degrading praetices that are so often the result of lalezess. And this is all in freeping with the prinsary object of education; for in encouragling activity, dfligenco, and purity, wo are eoaing into baraony with the Creator. 19

Young woaen, too, need to labon Indoors and out to leann house-

leeping and neatness and to butld strong healthy alnds and bodles.

The edueation which the young wen and wowen who attend our colloges ahould receive in the howe 11 fe is deserving of speelal attentien. It is of great importance in the work of character-building that otudents who attand our colleges bo taught to take up the work that

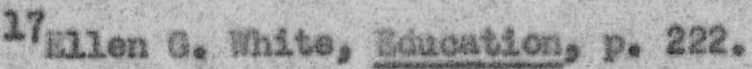
28 inien G. White, Fundenentals of Christsan Bdueation, po 315.
29 glien 0. White, Gounsels to Teachers, p. 308 . 
18 appointed them, thrortag off all inclination to sloth, They noed to becone fardiliar with the duties of daily life. They eliould be taught to do their donstie duties thoroughly and well, with as little nolse and confusion as poselble. Dverything should be done decently and in order. The kitehea and all other parts of the ballding should be kopt aweet and clean. Hooks should be lald aslete t131 their propez season, and no sorv stady should be taken than oan be attended to wlthout negleeting the household duties. The stady of books is not to engross the alnd, to the neglect of hose daties wpen which the coafort of the faraliy lepends, 20

The real, lasting happtness in 14 fe cones fron enjoglng our work. Approached wth proper traintne, work is a reereation-mespeolally for those purvulng books.

\#ัork as true rsereation:

1. Gives keen pleasure.

2. It brings health, laxorclse is then natural.

3. It reats the aind,

4. Work brightens the aye.

5. It qui eicens oirculation and respiration,

6. Work strengthens wasclos.

7. Joyful 2abor inoreases norve tone.

8. It provides the best in body-buliding valae. 21

The discipline for practical life that is gatned by plysical zabor conbined with nental taxation is sweetened by the reflection that it is qualleying aind and body better to perfora the work that lod designs aen to do. The kore parfectly the jouth understand how to perform the duties of practical 1ife, the greater wilu be their enjoynest day by day in being of use to others. The alind edtuoated

20 gulen 0, Ehite, Zeotimontea to the chureh, val. 6 , ppe 169,170 . $21_{A_{*}}$ E. Spalding, Growing Boys and Girls, pp. 234,135. (Adapted). 
to enjey usefus labor becones exlarged; through training and discipline it is Istted for usefulness, for $1 \mathrm{t}$ has acquirsd the knowledge essential to aake its posseseor a blessing to others. ${ }^{22}$

In this artificial, age the growing youth needs and danands the value Eained from "the olesentel Industries-work in the soll, work of buliding, work of providis in soise part the essentials of 11fe, "23

An honest days worli in itself teaches honesty, thrift, econowy and the value of aoney which too many in this generation do not jenow.

"A Iifatine of hard work bas shown ne the value of 11 thle things of every day, . they are at the bottoa of charaoter bullding. " $^{24}$

The studants aro in our schools for a apecial training, to becose acqualnted with all lines of work, that should they go out as Indsionartus, they could be self-rellant and able, through their educated sbility, to furnish thenselves with nocessary conventences and faclilties. Whether aen or wonon, they should leam to send, mash, and keep their om clothes in order. They should be able to cook their ow weals. They should be fanillar wh th agrleulture and with sechanieal pursulis. Thus they can 11 ghten thelr onn oxpenees, and, by their example, lnculcate principles of thrift and escnoty. These lassons can best be taught where seonogy in all things is consclentlous 2 y praetleed, 25

It 1e not benefiolal to gros up shielied froa works It la not good sor parant or ehlid to Cellver a student at the acadery and to announce with pride. "Ile doesa't have to work." Why "get" educated and then Iater hevo to leam to work? It is far better to traln one to expect to work and to enjoy 1 .

$$
\begin{aligned}
& \text { 22 EIlen 0. Thite, Counsels to Teachers, p. } 309 . \\
& \text { 23,. "I. Spalding, gp. eit, p. } 127 \text {. }
\end{aligned}
$$

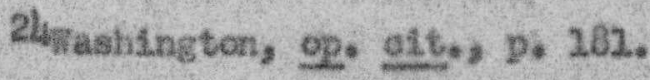

$$
\begin{aligned}
& 25 \text { muien a. White, zostinonies ror the church, vol, 6, D. } 208 .
\end{aligned}
$$


Cod oreated a working untverse. "From the insects to the angels,

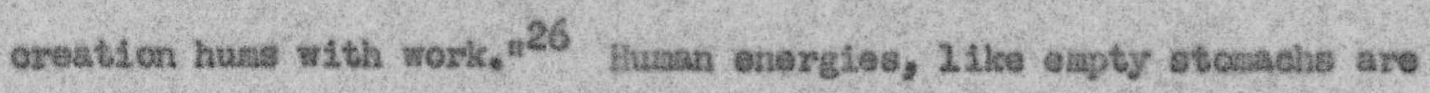
self-destruetive, unlese guiced purposefuliy. Streass are purifled by wotlon. "IdLeness is the groatest curse that can fall upon sans for vice and crine follow in lte troin, ${ }^{27}$ Perhaps aedera corruptlon stess

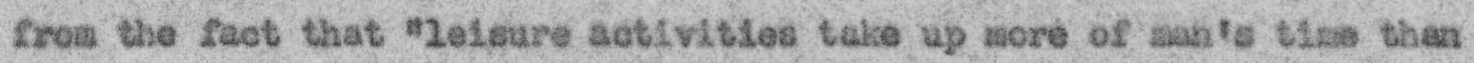
work activity, ${ }^{\text {28 }}$ nsix diys shalt thou 1abor, n $^{29}$

"Behold, this was the Iniquity of thy aleter Sodos, pride, rullnoss of bread, and abunciance of 1dieness, "30 $^{30}$ Character cannot be oreated In a vacuun.

Cod designs that all shall, be workers, the tolling beast of burden answers the parpose of 1 tis creation better thas does the Indolont man. God is a eonstant worker. The angele ase workters; they are ministers of dod to the children of men. Thcse who Look Iorrard to a hoaven of insebivity wi11 be disappointedy for the econony of haaven provilies no place for the gratifleation of indolence. But to the woary and heavy-laden rest is pronised, It is the fat thful servant whe will be weleoned Iros hile jabors, to the Joy of his lierd. Ilo wi13 lay off his araor with rejoloting, and will forget the nolse of battle in the glorious, yest proparod for those who eonquer through the cross of calvary. 31

Civilizations have been bulit by 1 abor, destroyed by unaceded 1elsure. Rose was destroyed by imported barbarlans aftor 1 rotted in

26 atehard Clarice Gabot, What Len Live By, D. 23.

27,2len 0. whate, Petriarchs and Prophots, p. 156 .

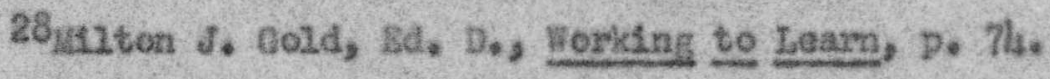

29 ix. $20: 9$.

30 Lae. $16: 49$.

$31_{\text {gulan } 0 .}$ White, Gounecls to Tesehors, po 280. 
Imoral lelaure. As amold Toynbee sald, "We breed our omn," barbarians. 32 Sono so-ealled Chriatlai sehools, by negleoting to offer a balanced program, have actually helped to culture this breed.

True letsure is roereatlon, the remard of real Iabor. Sest tastes good ondy after labor, food aftor exertion, the sabbath after a weok of work. The Sabbath "puts our daty work in the perspeotlve of etemity and thus rodtuees it to 1 te true proportions, "33

An old Latin proverb is "Laborare est oraze." One who labors in sincere devotion to bis tabk is lost in $1 \mathrm{t}$ as one in sliscero prayer. Both Iabor and prayer teach rospect, 3 . U. Heron sald,

It is a satter of conson experlence that the Laborer eosotlees loses hireelf in his work, and when he does so his load is eased. There is a strong reseablance between this condition of the body absorbed is what we call work and 1 ts state in the silence we call. prayer, and the reason for the resenblance is that in both casea ian 1 is giving hinself to cod-in tha one Instance to ocd at work
in the natural oreation, in the other to cod at rest in the spirit. 34

Those who are absorbad in useful labor to propare thesealves to serve, or to help in a groat cause have found the secret of service and the key to true happlnese and real xiches.

Fredarlok Griggs, an cusstanding Seventh-day Adveatiat educator, told of a trusp who aase to his door asking for food, llire, Grtge opened to him and pointed bin to s plle of wood seedsng to be cut. The nan suld, "gady, have you ever seen an expty bag stand up?" She brought hin in and

\footnotetext{
32. R. Inge, The Idee of Prorress, p. 13.

33. J. H. Oldhas, Work in Nodern Soetaty, D. 55.

34 mide. p. 55 .
} 
fed him. Then again she motioned torard the wood. She tralted nomentarliy for the man to proeeed to the task. Instead he satd, "Lady, have you ever seon a frul bag bend over?"

True edueation for character and servioe aust not be allowed to wanelor as a tramp. It is oasy to be oapty of convietion or too fual of viong Ideas to pat work to work, 1ittle realiaing that it is the koy to econonie, social, intellectual, and splritual problens.

The thousande of greduates from Seventhoday Adventist scheols around the world and the practical service they are rendertng in vartous waye are the roal test of thelr priotleal phisosophy of educatlon. 35

35Laurene Aleo Flansgan, "Industrial Eduaation in Cur Sotools,"

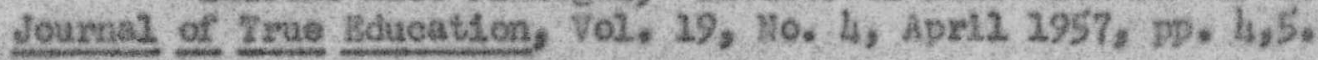




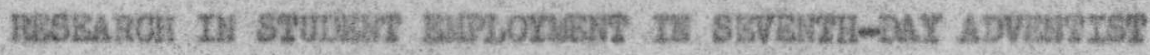

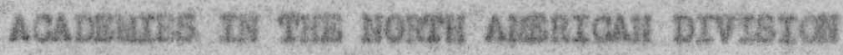

Dirty-four, or $72 \%$, of the prineipals out of the seventy-five in the twelve-grade agademies of the North Aneriean DIvielon rosponded to a questionnalre on student labor. This chaptar w111 roveal the faots derived from the seventeen queations asked. In these 54 schools 8,800 studente vere enrolled in the $1954-59$ sehool year. of the 54 schocls 32 are boarding schools, and 22 are 11 sted as dey schooles 32 are Located in rural axeas, and 23 are located in urban surroundingos In the boarding sohools the exrollivent is 5,72h. In the day schoole the ourolinent 1e 3,076. See Figure 2, page 31.

As can be aeen fron Mgure 3, page 32, 307 of the otudante worksed 5s of theix way, 407 woriced $10 \%, 2,233$ worked $25 \%, 2,073$ worked $50 \%, 437$ worked $75 \%$, and 24,0 worked $200 \%$. This IndLates that 4,184 students worlied 5s or more of thelr way through school, while 4,626 wortied none or verg 14tule. soe Pigure 4, paco 33.

or 8,800 students, 4,777 are omployed areans the 23 industrtes

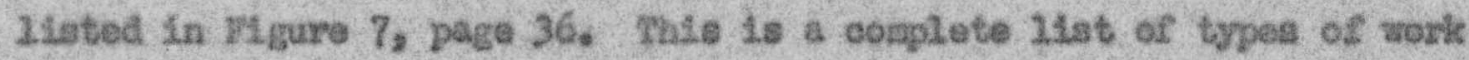
subaltted by the sehools. Dvan though 2 it met be renembered that 3,076 are onrolled In day schools, the major coneern should be for the 4,023 otudents who are listed as havlig no sohool-fumlshed eaploynent whatsoever. See Flgure 2 , paga 32 . 


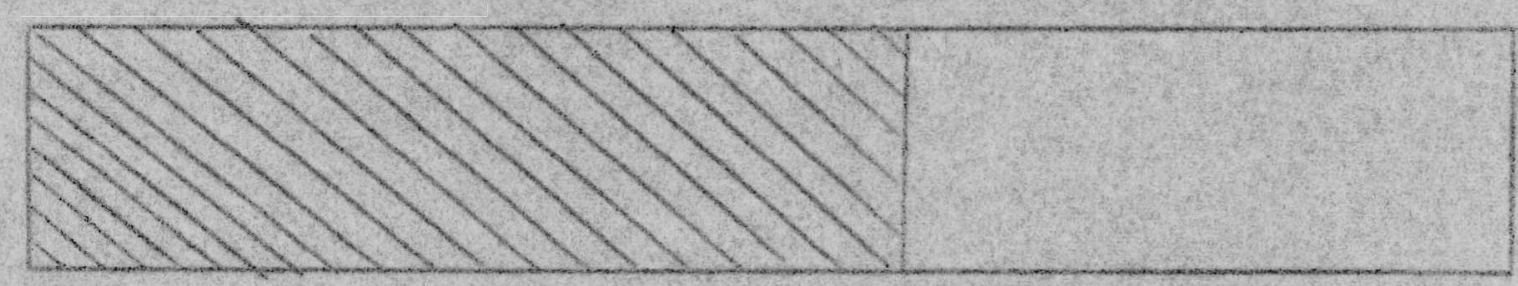

Nurber of Boarding Sohools 32, or $60 \%$

Number of Day Schools 22 , or 4003

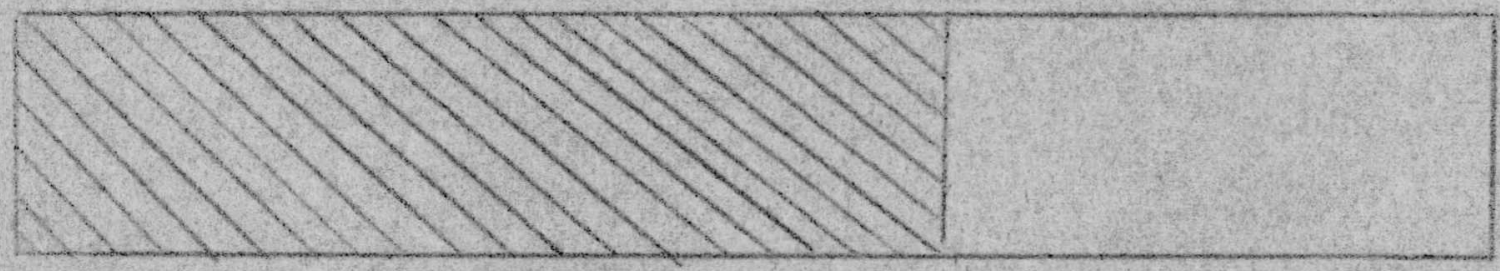

5, 72h Lnrouled in Boarding Sehools, or 658

3,076 Enrouled in Day Schoole, or 358

\section{Froune 2}

BOAmINO AID MA BCHOCAS COIPARS 


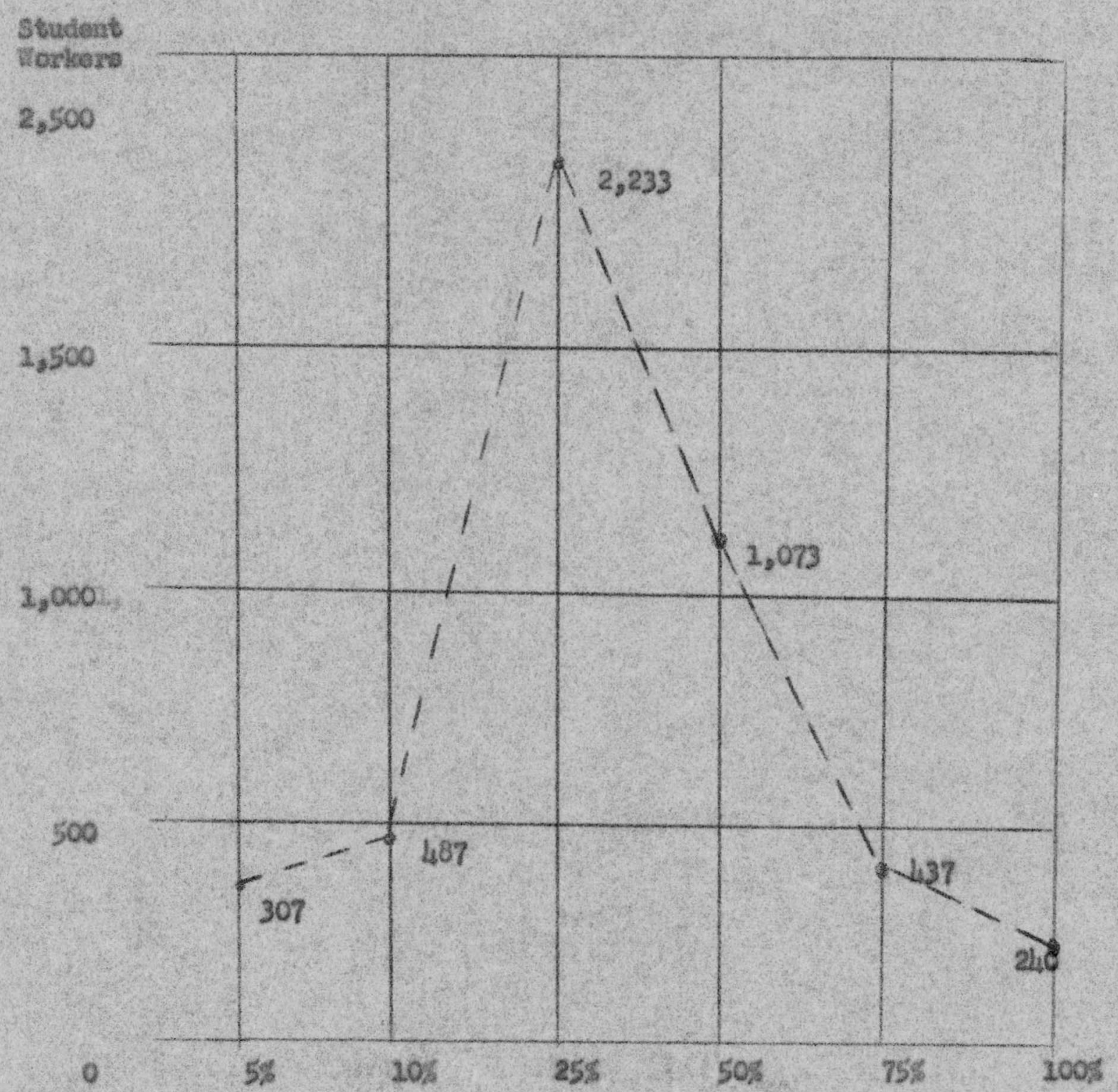

Percentage of Way Jarned at Sehool by Studente FTaUR 3

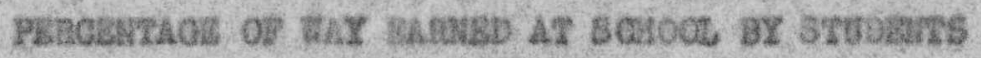




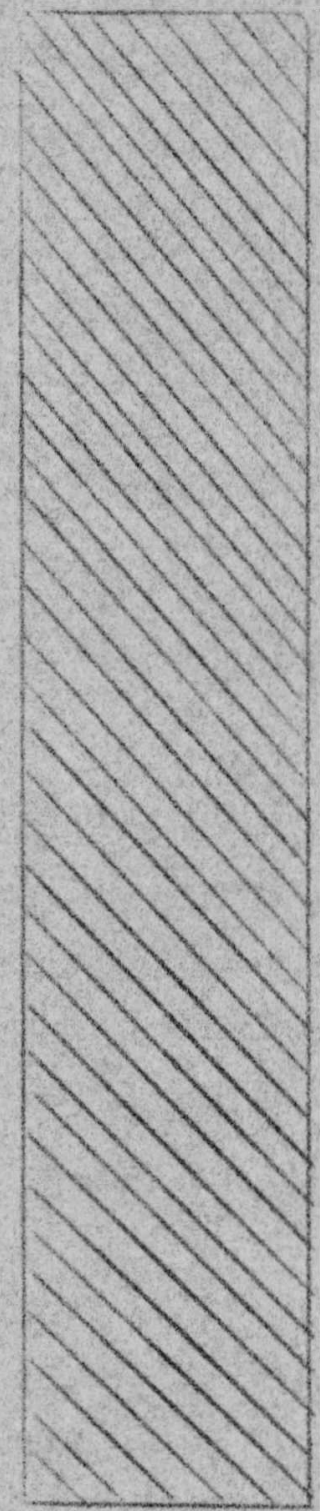

8,800

Studenta

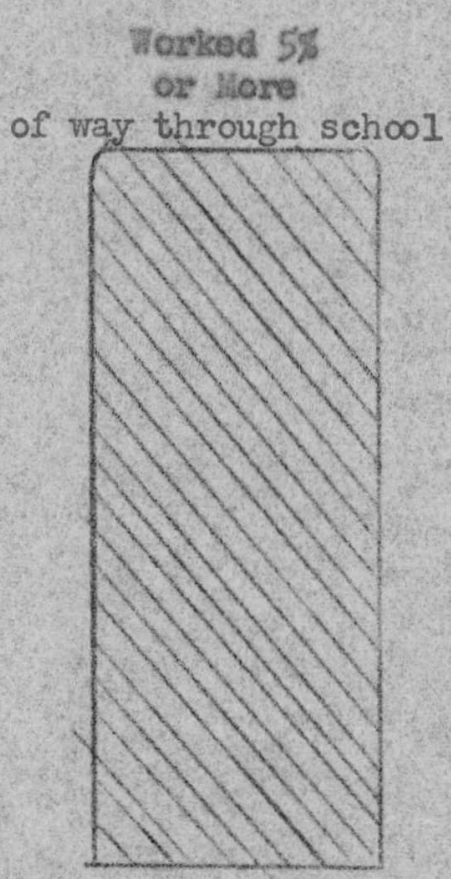

Selool Euployzent 4,284, or $47 \%$

\section{Frours 4}

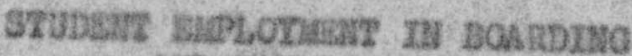 AED TAY schoots}

Ho Behool Inploymant 4,616, or 53 ; 


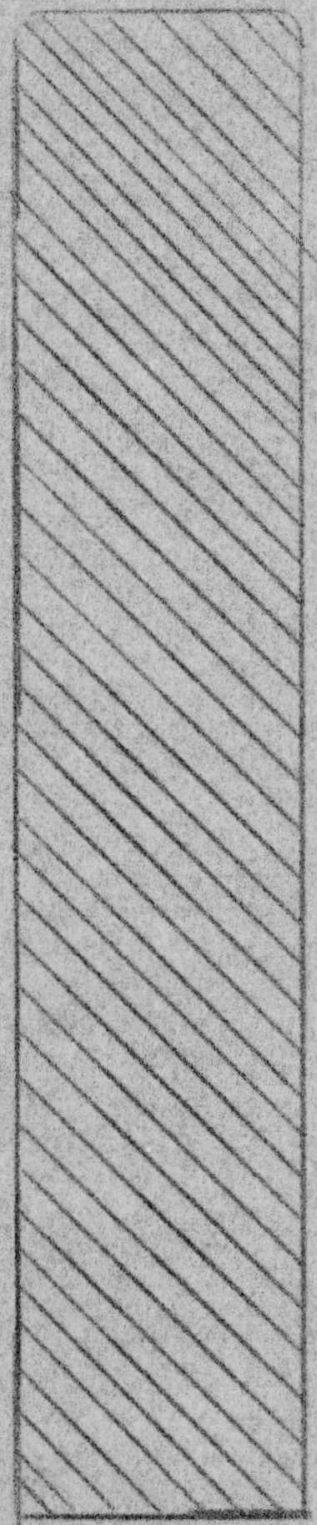

Botrding A oadeny Studesta 5,724
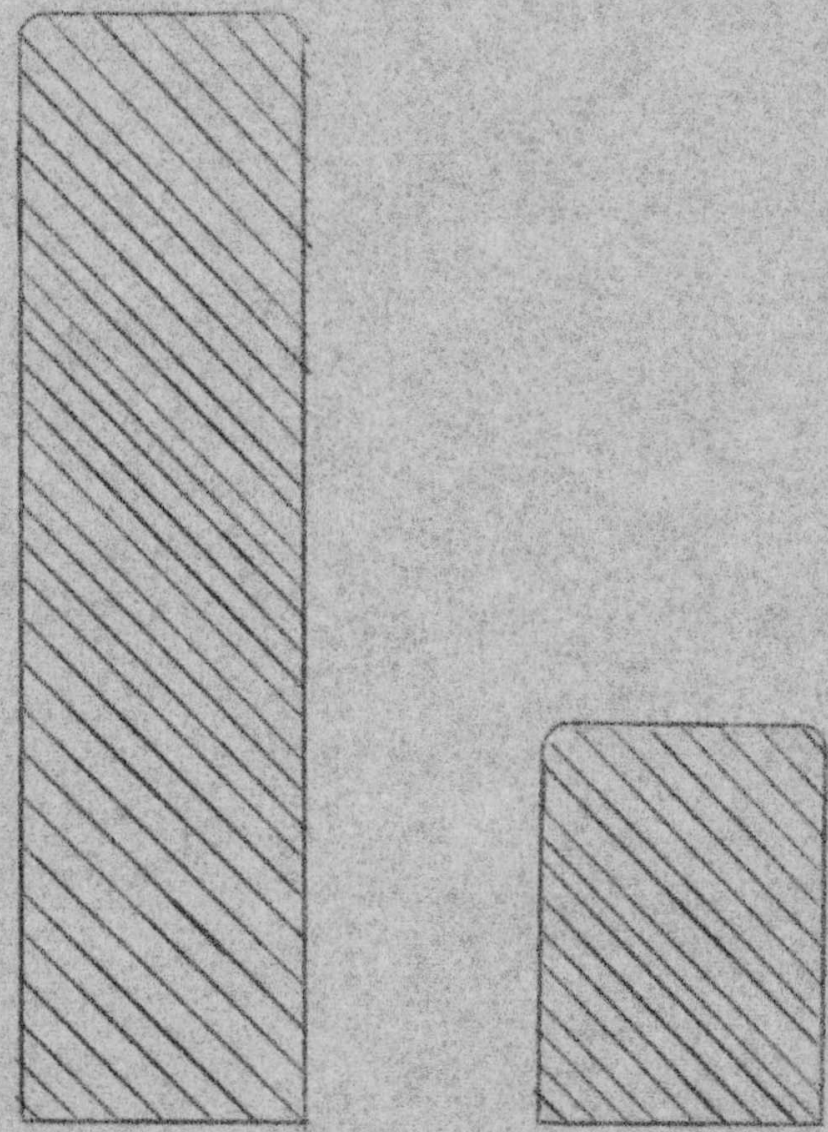

Barployed at Scheol 4,235 or $7 / 4$

\section{ricuma 5}

\section{boh Drno ACA} EMLOTE AT sChoot. 


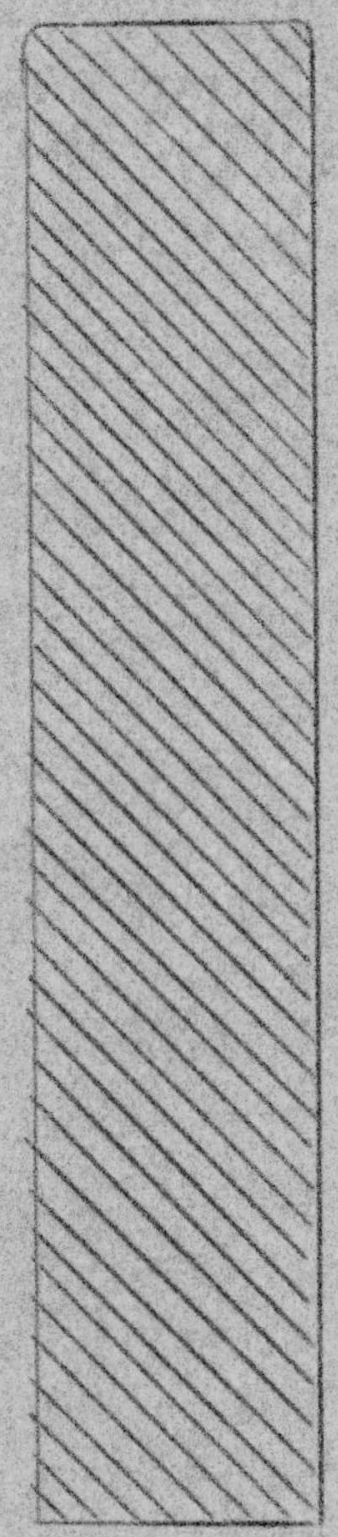

Day Acadery Studenta 3,076

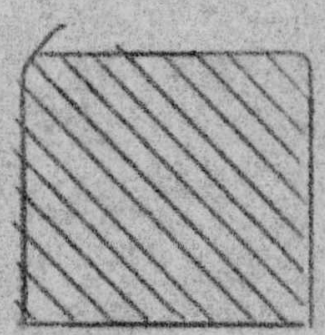

hmployed at sehool 537 , or $27 \%$

vtuvas 6

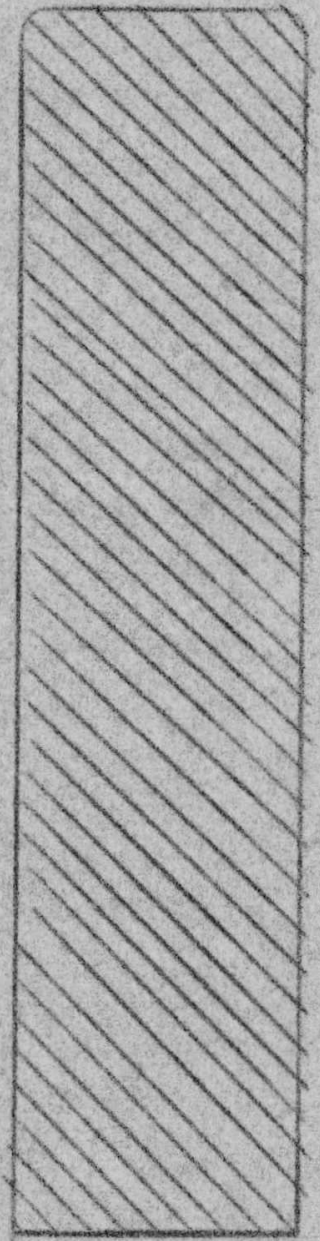

Unemploged at Sohool 2.539 or 83: 


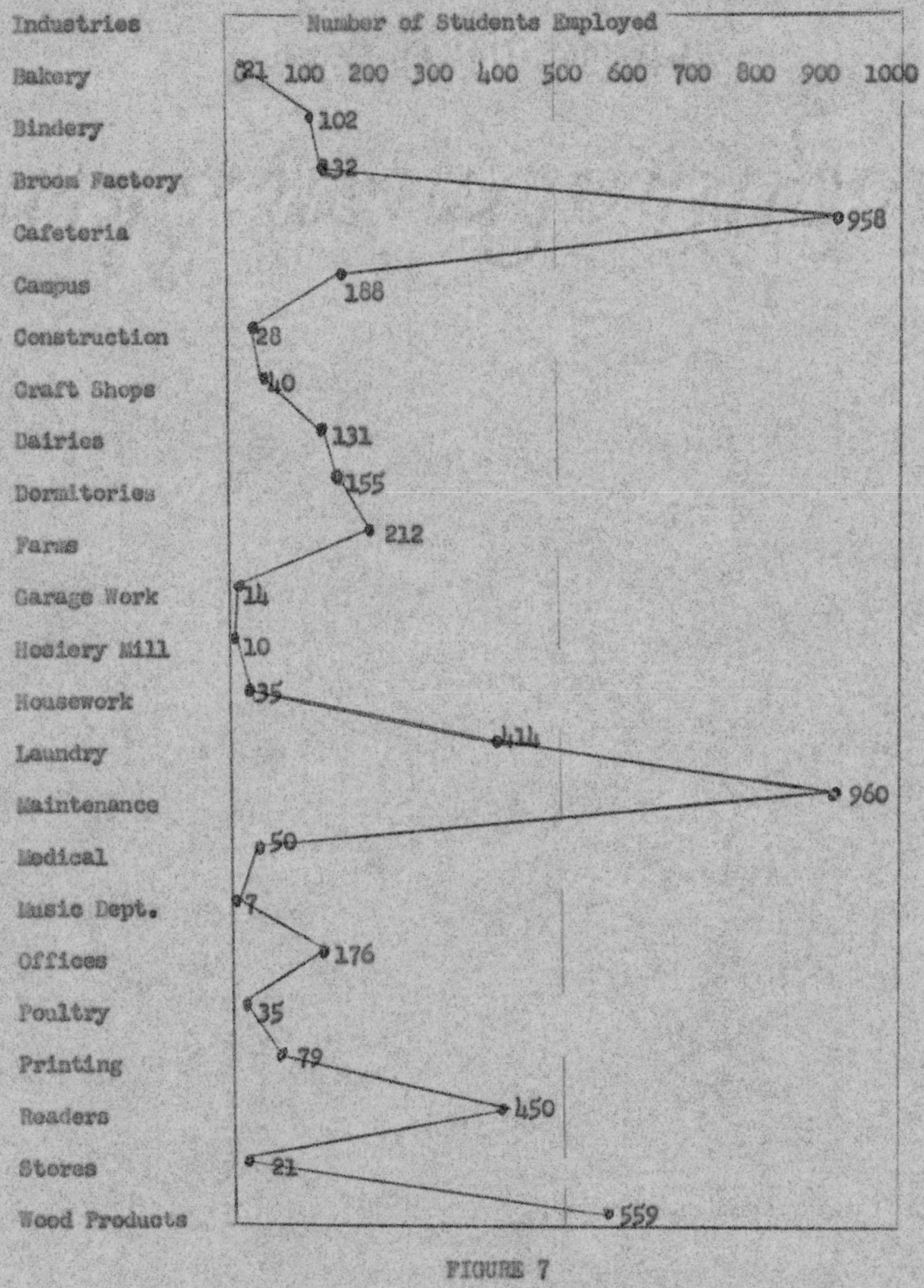

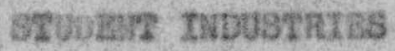



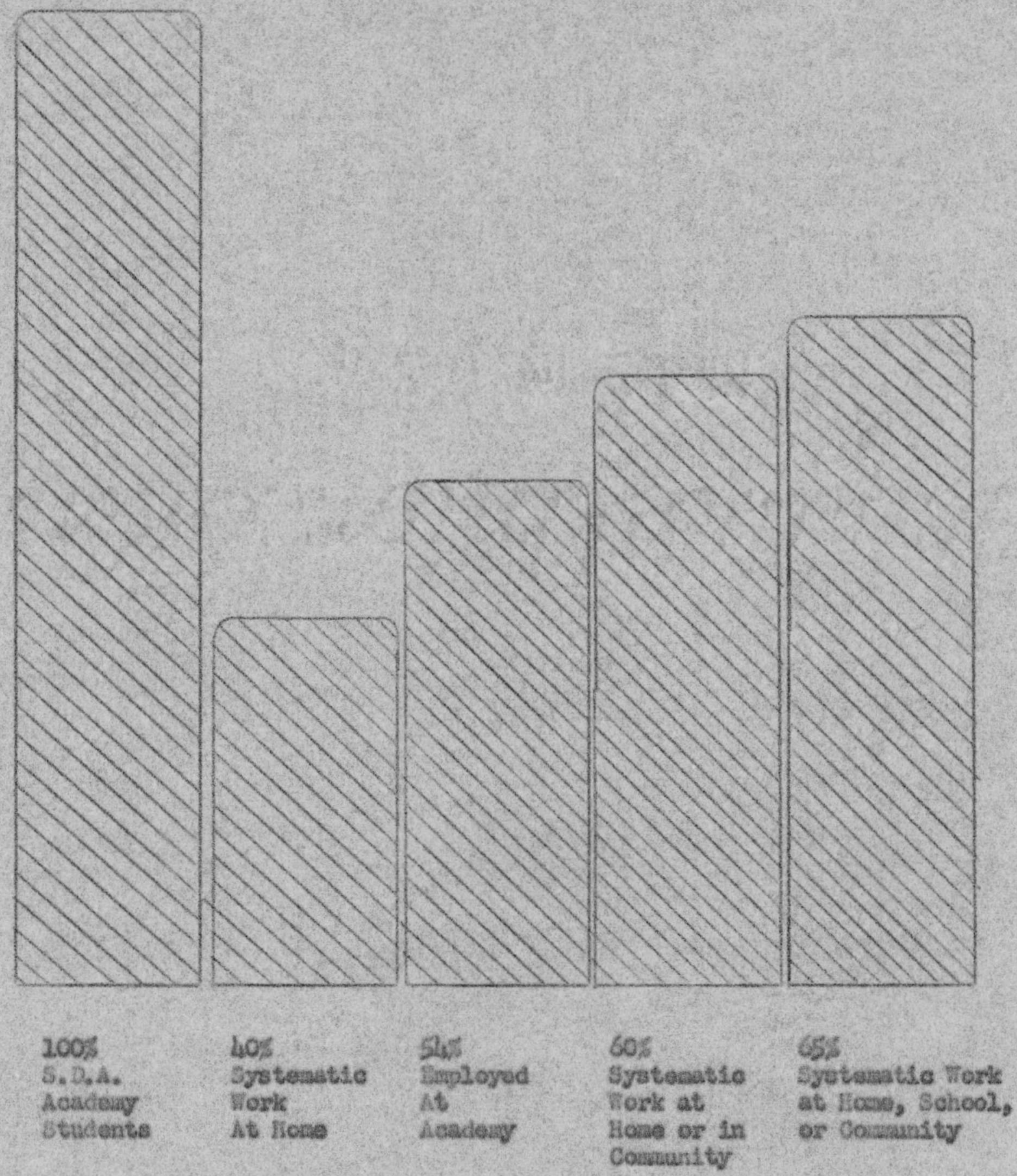

yioura 8

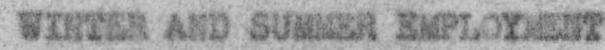
DSTruTES 
Froa the best estimates obtalnable, 14 appoars that 20 se than 408 of the atudente have somo lind of Eystenatlo work at hone. Even Inelud-

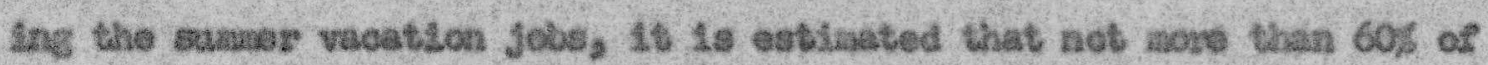
the bearding and day acadery atudents flnd ayoteratlo worth at hone os In the cossuntty. Wot ware than 65s find work in hone, echool, or concantig. See rigare 0, De 37. Fhat zeaves 358 of the studentes completely tenemployad at all thes.

Ilost Soventh-day Adventiot asadeales to not roquire a dinimas

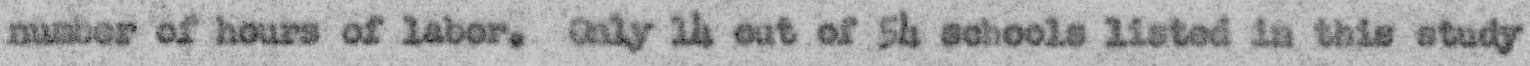
rogutire a mintama number of hours of 2aber. Shile regulveatant runs frou 5 to 26 hours por week per stndent, Sone schoole in planndng theLr curniculus made It part of the progran for aly, rich and poor alliw, to vost fros 22 to 18 hours poy suek, The average anount actualy worked Ly those erployed was 10 l heure per week,

In day echools of urban areas, whore farki anú howe chorob are

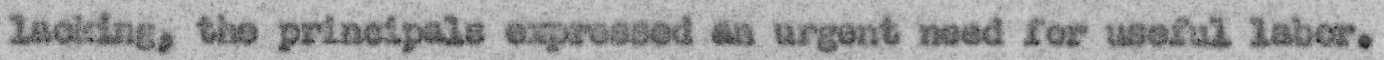
The fougoring staterante aave fros the prinelpals in rosponae to the guestion, "mast, in your cplndion, ts the relationship of stadent wark to character bullaing?"

"I seel $1 t$ pluye a vosy laportant part in tesching car young poople hew to take on resposetbusity and leaderehipg"

"wost inportant-basy, hard-working young people are too busy to got into atsehtef."

"Very gcod charagterwistlding progras," 


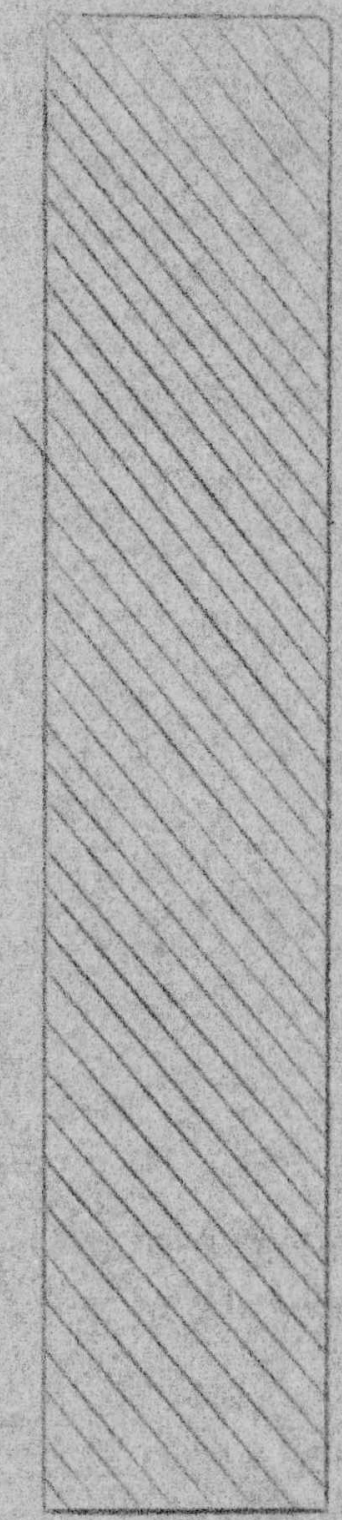

54 Acadentes In the Ploport

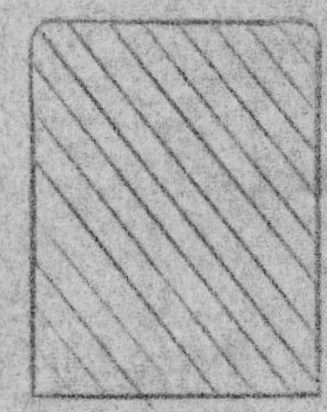

44, on 25t Required a Ninibus of Labor of all students

\section{moum 9}

BRQUนeED LABoR mootus 


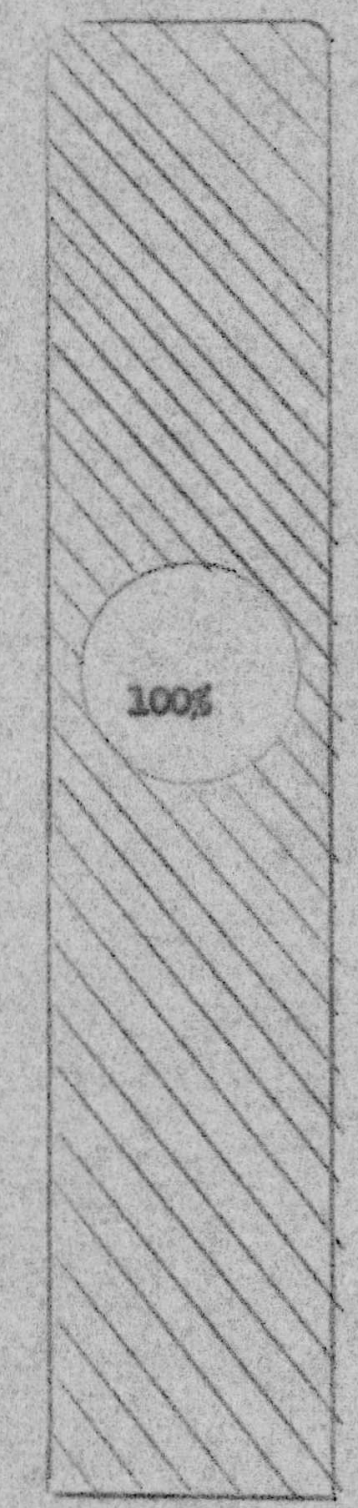

54. Sehools Reported

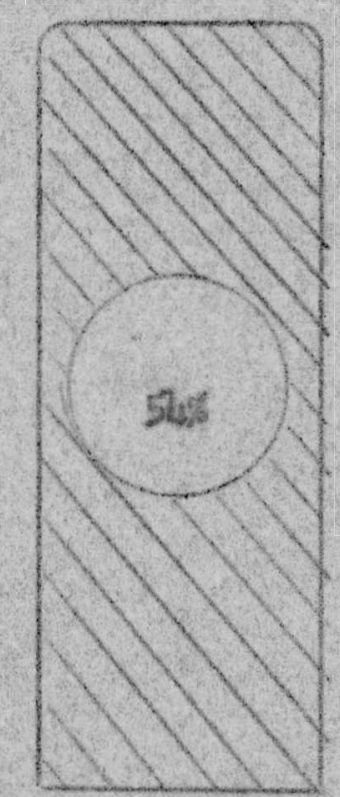

$29 \mathrm{Had}$ Hot Diropped a iajor Industry

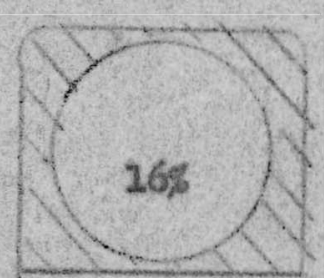

9 Reported Indus tries Droppee

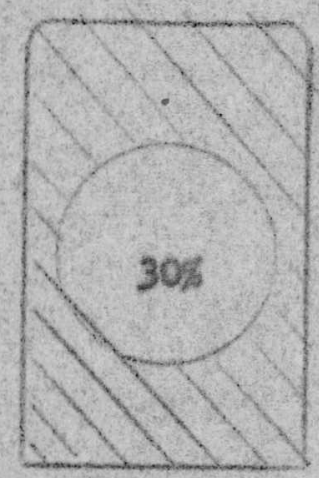

26 Diant Ancwers the Questlan 


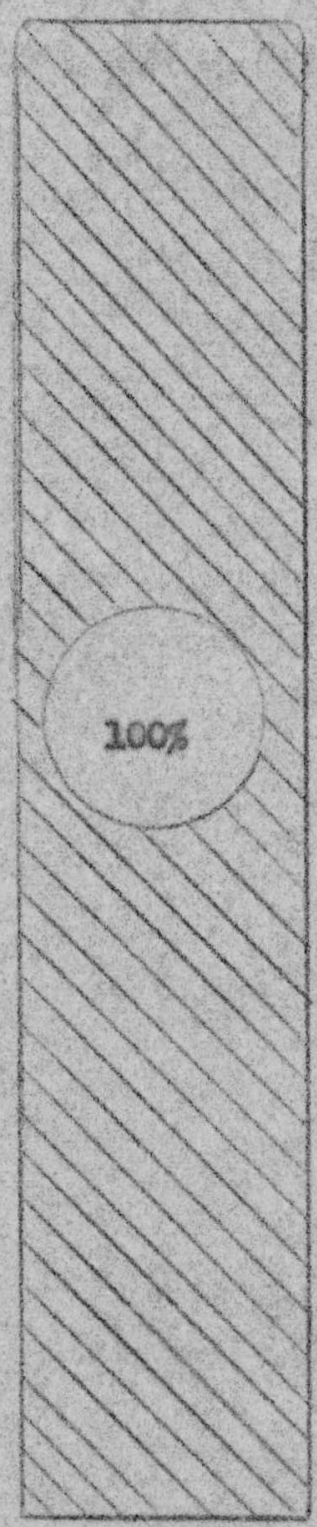

54 seported

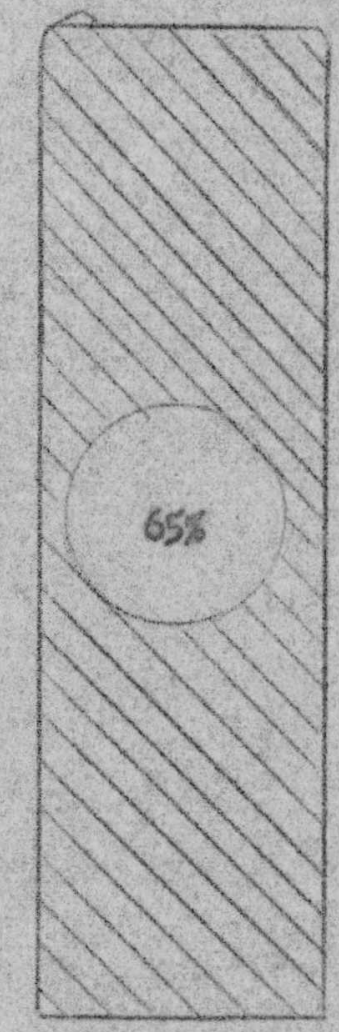

$35-110$

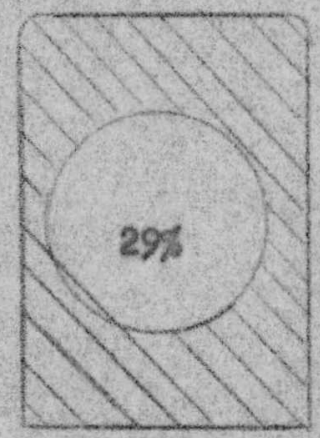

$16-103$

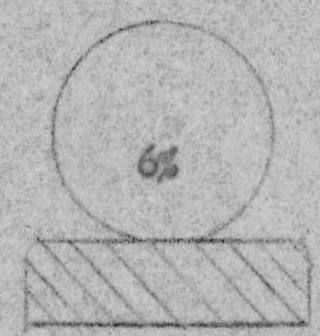

3-Jo Response

\section{rrouns 21}

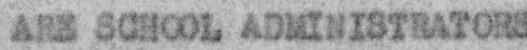

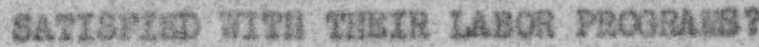




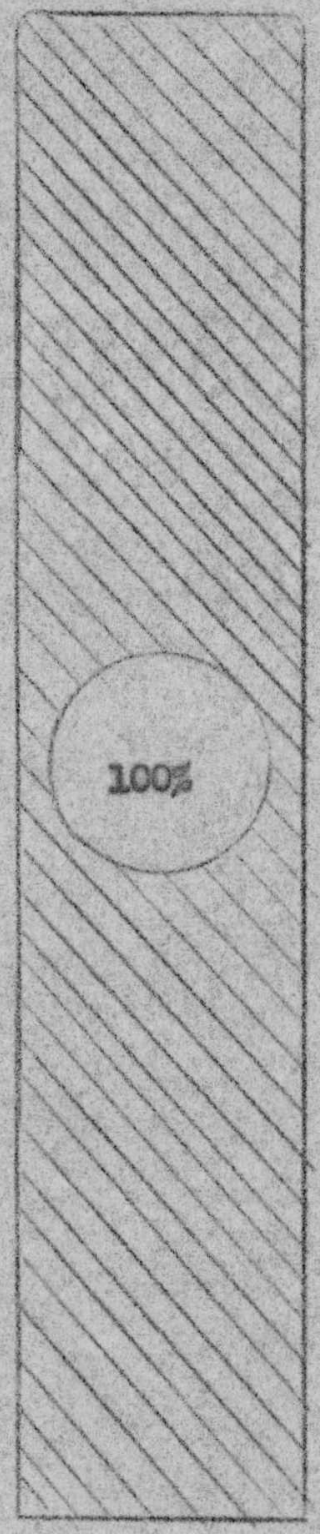

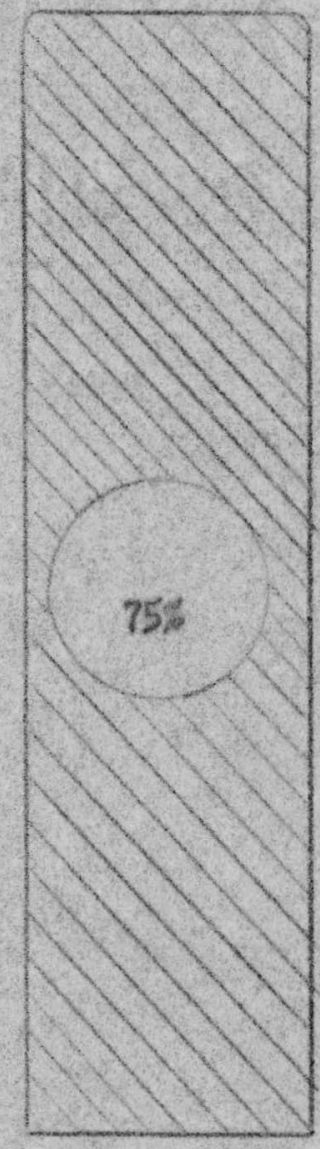

$42-10$

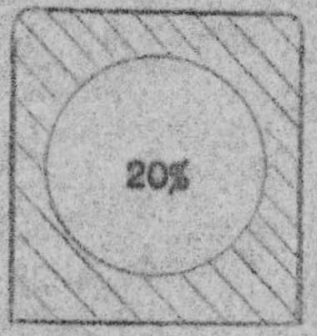

21- -

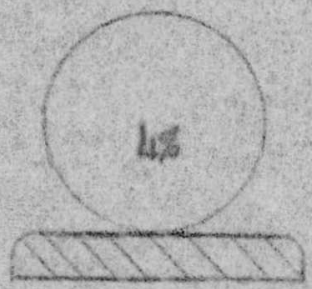

2-lo opinion

54 Bohoals Ieportad

\section{BIoUne 12}

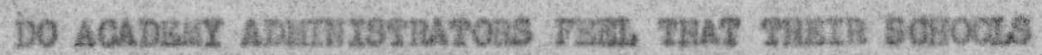

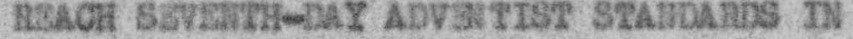


nise rind that thase tho do not work do not always rocelve the best gredee. Instead they are usualy the problen atudenta. Thoee who work are usually nore dependable and aore responsible."

"The dovelogaent of ekavactor and manual labor aze Ineeparable,"

"absolutely essentlaal. I juat had a conference with the state Divlelen of tndustrial Folfore. . . . Thay heartly apsove of the work prograes and tronder why it is not in tho day acadendee elso if thie is our phllasoghy of educakion,"

"Studont wosic is eseentlal to charaoter building in that it providee the student opportanity to ahare responaLbiaitgj-obaring a part of the finazelas responsibility he reallaee nore the coet and purpose of his trating

"I thinik a rogulay dally work proman is absolutely escential In an educational progras,"

"I don't belleve chartoter is ever complete without oxpostence In practleal work, IAn education derived chlerly fros books leals to superfietal thinking," sd, po 20 ."

"I wouldintt want studoats hore who do not works"

nVery necessary to teach the value of work, Mis, woney, and resyonstbility. It keeps thes out of nost rafechlef"

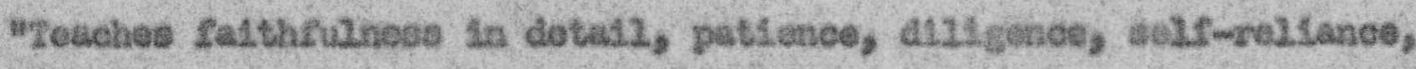
and to hoalth-bulleing,"

"ahe students who work are the hogptest." 


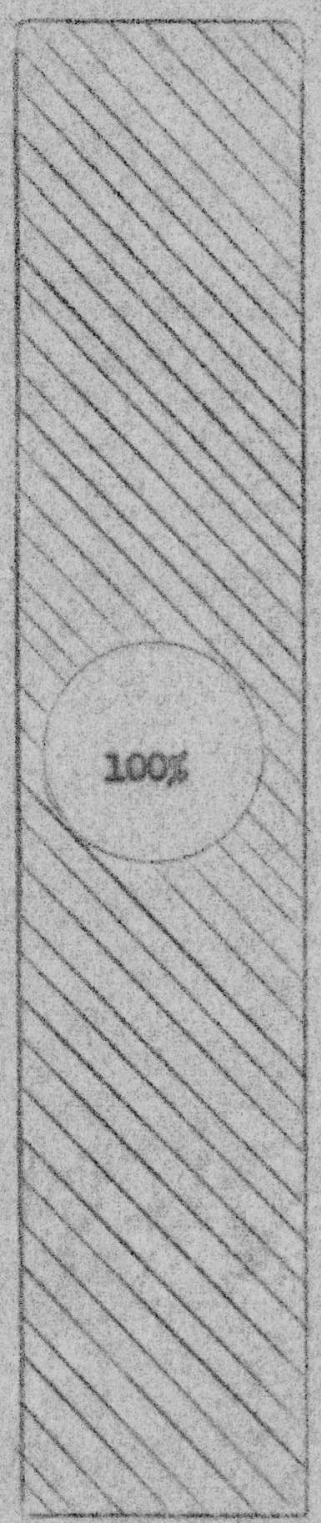

54. Selicols Reperted

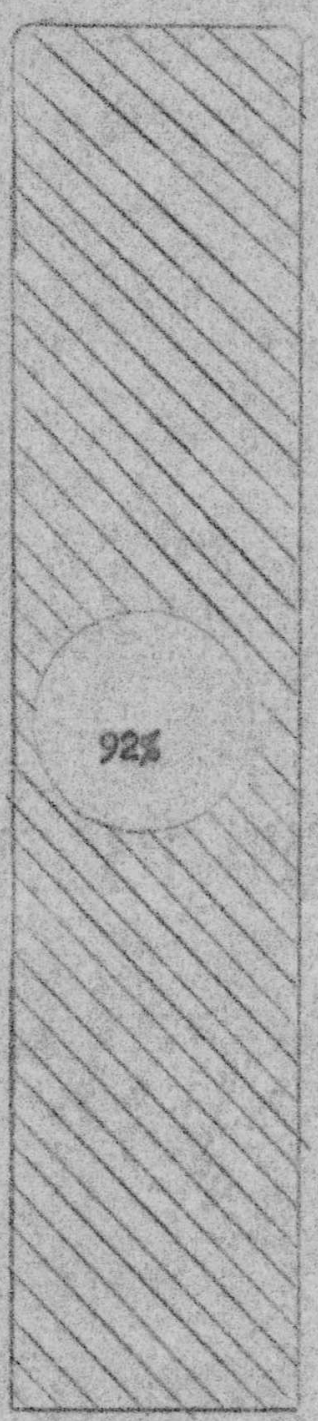

50 - res

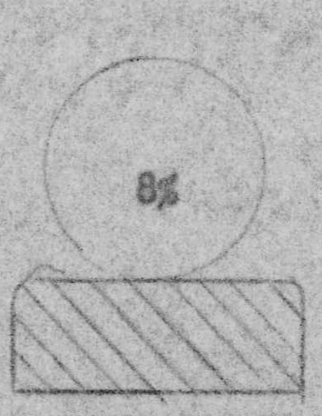

4-ivo optrien Exprosted

\section{Fxcure 13}

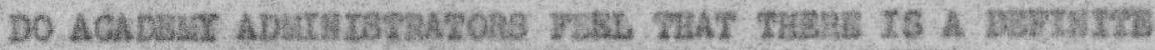

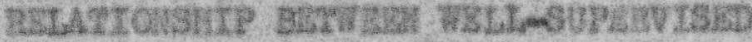

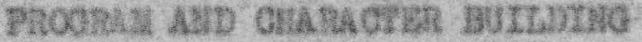


It is interesting to note that $60 ;$ of Seventh-ciag Adventiet aeademies are boarding sohoble and that $60 ;$ of Seventh-day Adventist acadontes aatntaln farras. The 32 farn atudied in this ropert total 21,677 acres, en average of 365 acres per farn, There are 212 students exployed on these 32 faras. Sach farn onployed an average of 6.5 students. The average $10 s e$ per farm was $\$ 6,210.96$ in $19586^{2}$ The day wi12 eans when these saras will be worth a grost anount to the educatlonal progras. Booker $\tau$. Washington wrote in 2904 , "yory often 1t would pay the institution better to keep a boy away from the fara than to have hin apend a day at work on $1 \mathrm{k}$, bat the farm 1 s for the boy, and not the boy Sor the farme $n^{2}$ He further potinted out that as socn as a stucont reaches a point of efficienoy he 18 ready to gradtuate. Wany of the echintetrators wor6 doss in thelr statenents that the farme as ner oporatod rolther pey finaneialiy nor educallenaly. The student body as a whele learns practlealyy nothing about acriculture as a vocation or baele thy of sustenence in thice of enorgency. The whole studant boty and faoulty as a group, do not get dafiy excreice in the open air as strongly rocowended In Beventh-day Advenulet phizosophy of edueation. OnIy 654 students of 8,000 enrolled in 54 scadentes, or $13 \%$, work regularly cutdoore.

more are 1,267 cows ca 26 farke having dafiles, ox an avorage of 46.5 cows per dalry. Each caury exployed an averege of 5 boys balding a total of 232 boys working in cal ries.

2 analysis of Acadear Farse," 1958, Caneral cenference of Seventh-

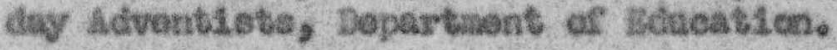

${ }^{2}$ Booker 2. WaahAngton, Goriking W1th The Iands, D. 63. 
suye Xreavev

\section{Tर รसकota}

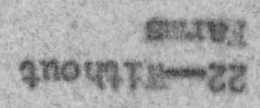

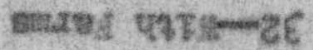

\section{3trthntodent \\ stooteg Th}
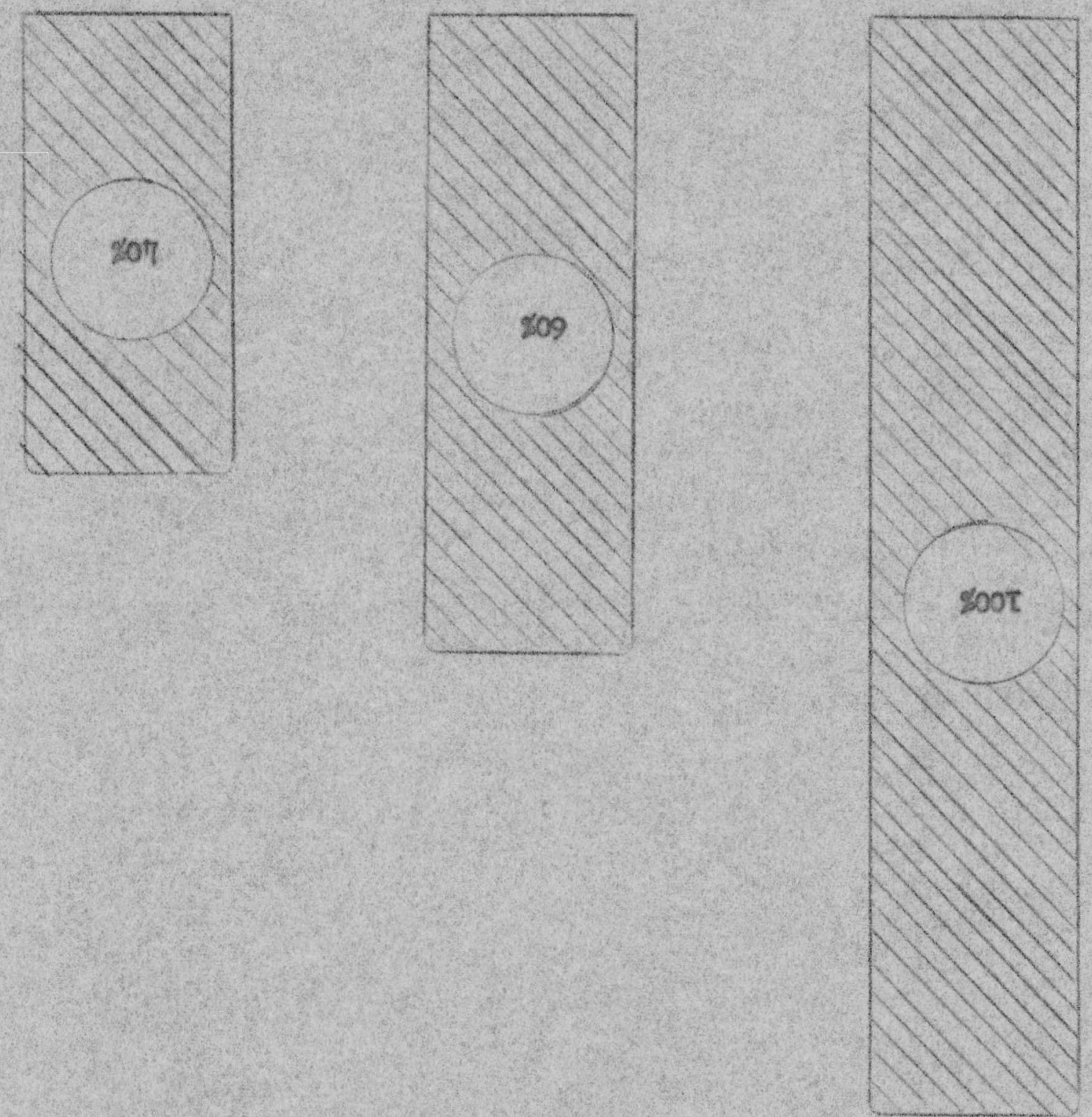


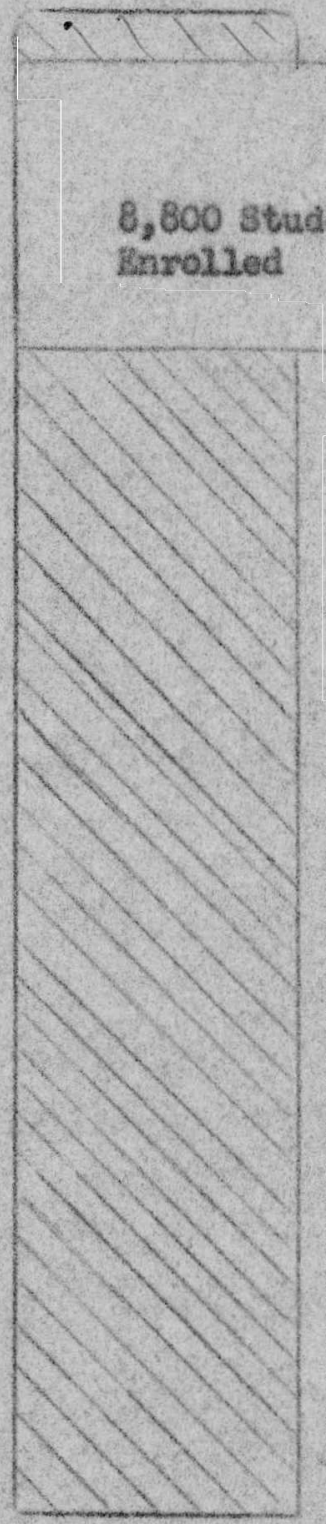

54. Acedenates Beporting

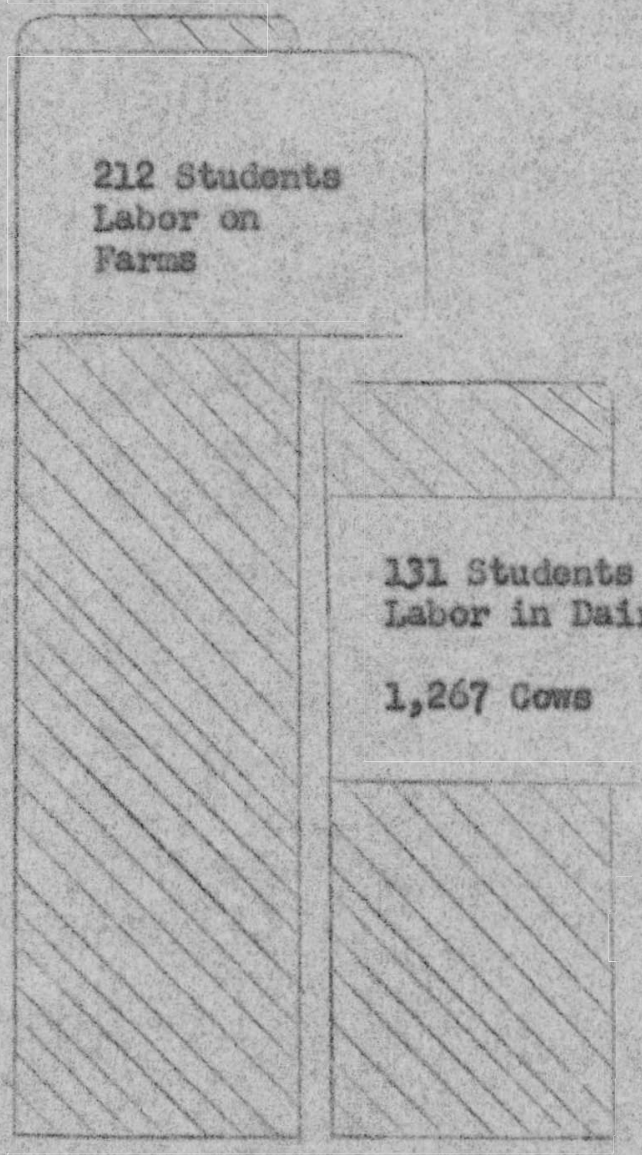

32 parus
26 natriea

7rouss 25

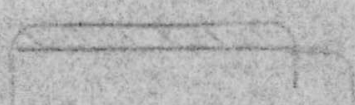

35 Students Labor In Poultry

31,925 llens

23 chleken Burse
17

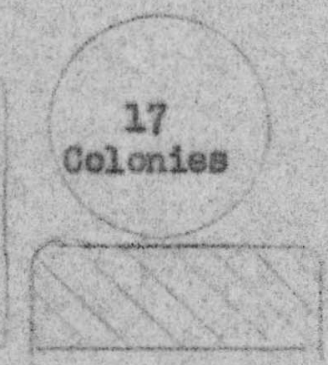

2 Aptarios 


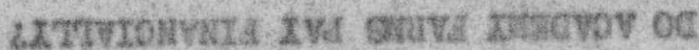

\section{$9 \mathrm{~T}$ gunore}

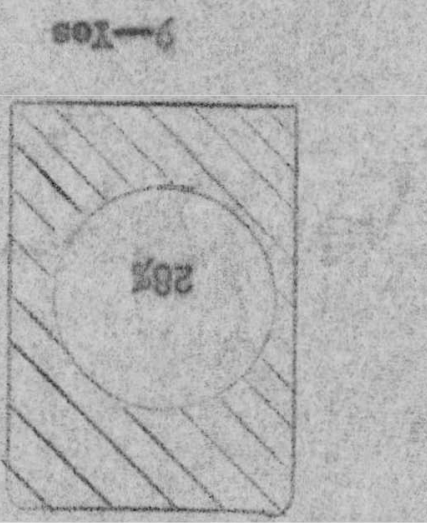

\section{olpmenge}

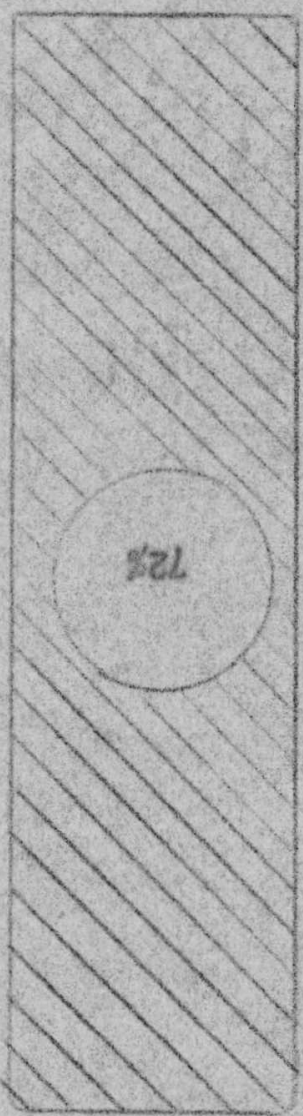

sure: Tenot $Z E$

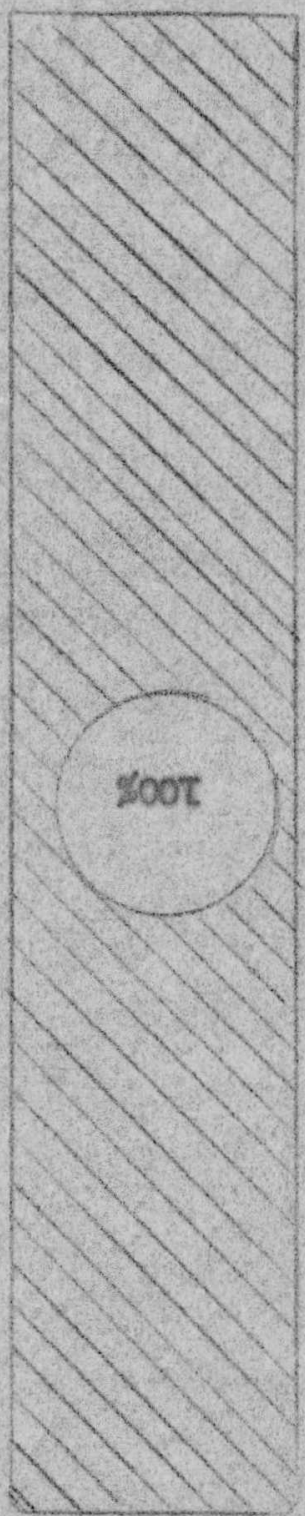




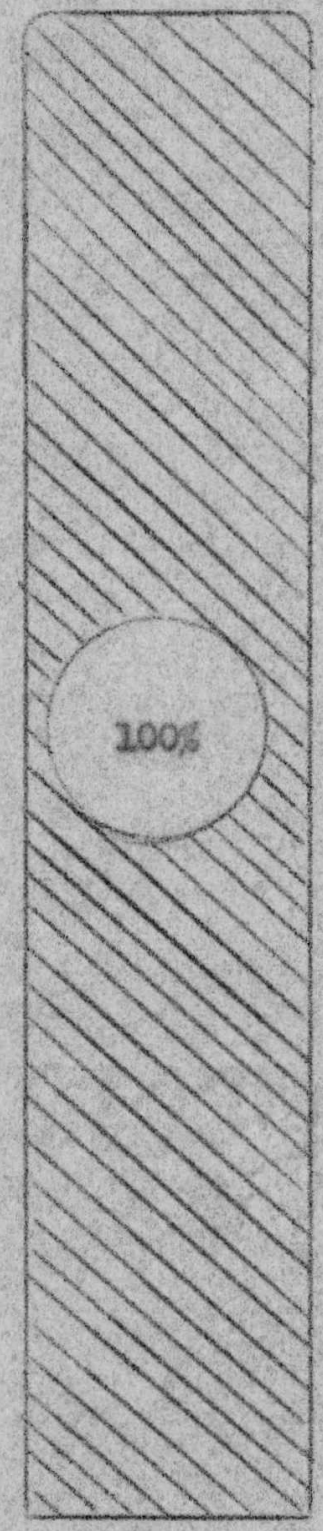

4h Answared Guestion

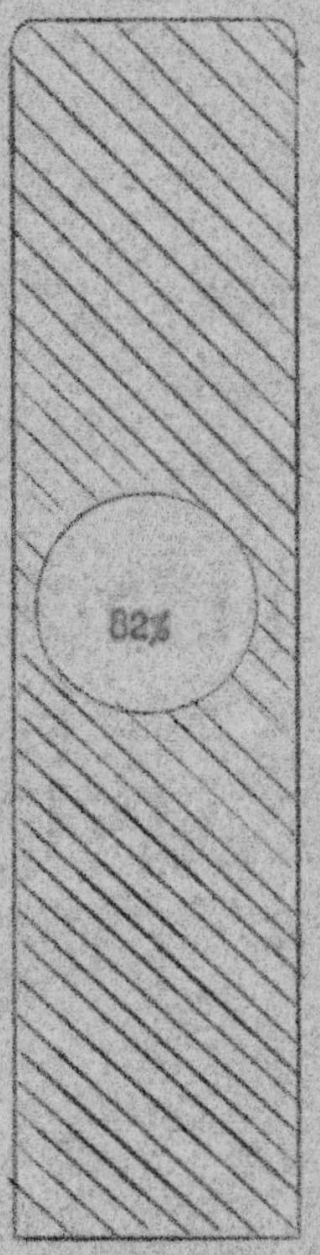

$36-\mathrm{res}$

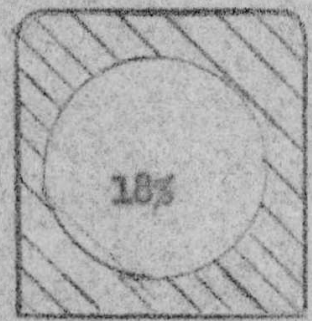

Oneno

\section{mavns 17}

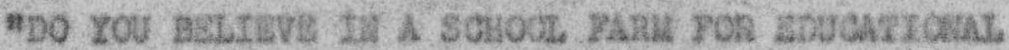

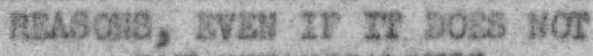




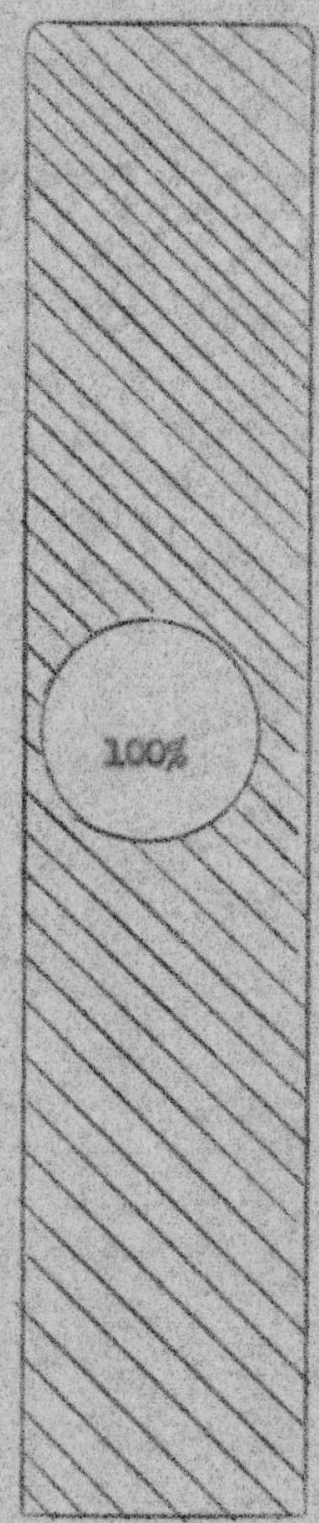

54. Roported

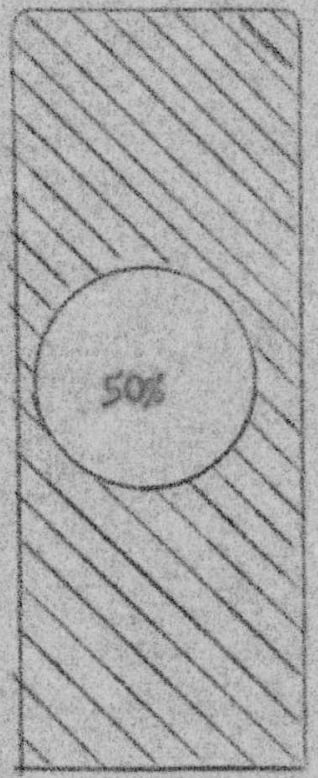

$27-$ Kea
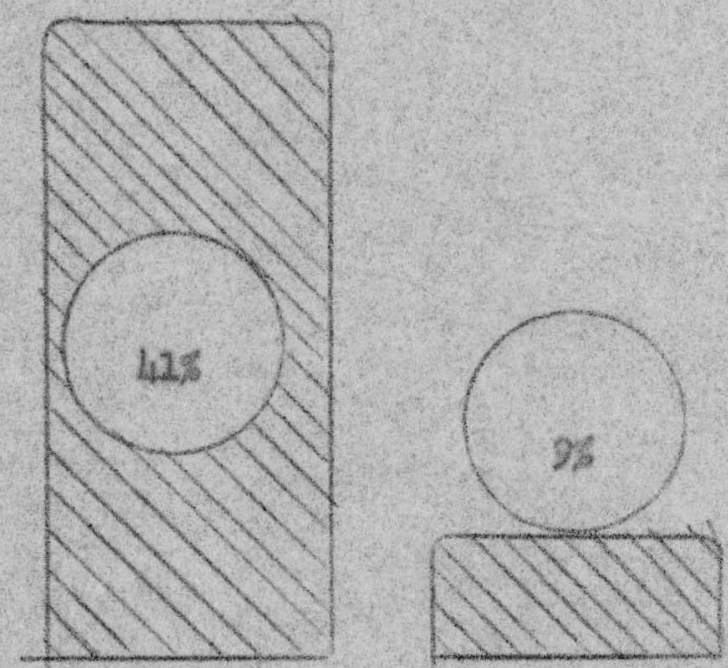

5-Tndecided

\section{y}

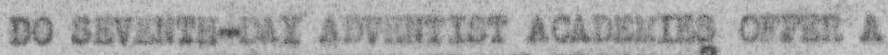
BALAtCED FotK-3TUDX PROCIRI? 


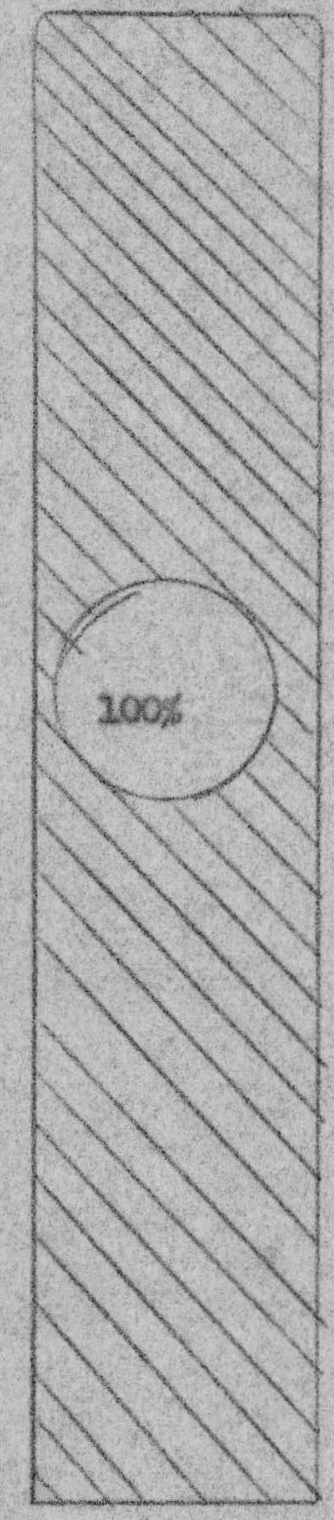

54. Coported

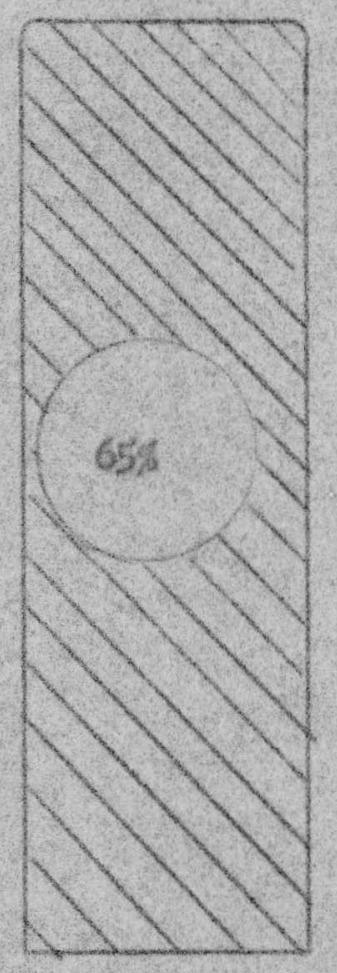

$35-$ Ios

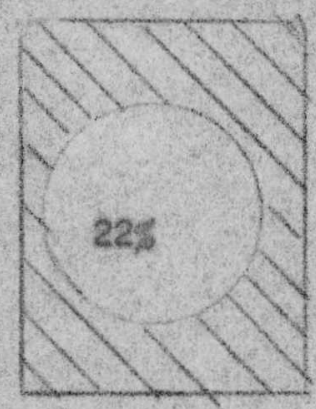

$12-10$

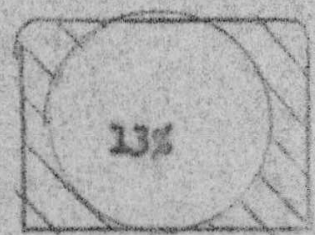

7-ilo Exprensioa

moun 29

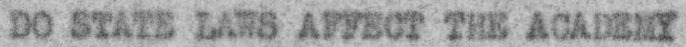
LABOR PRocizar? 


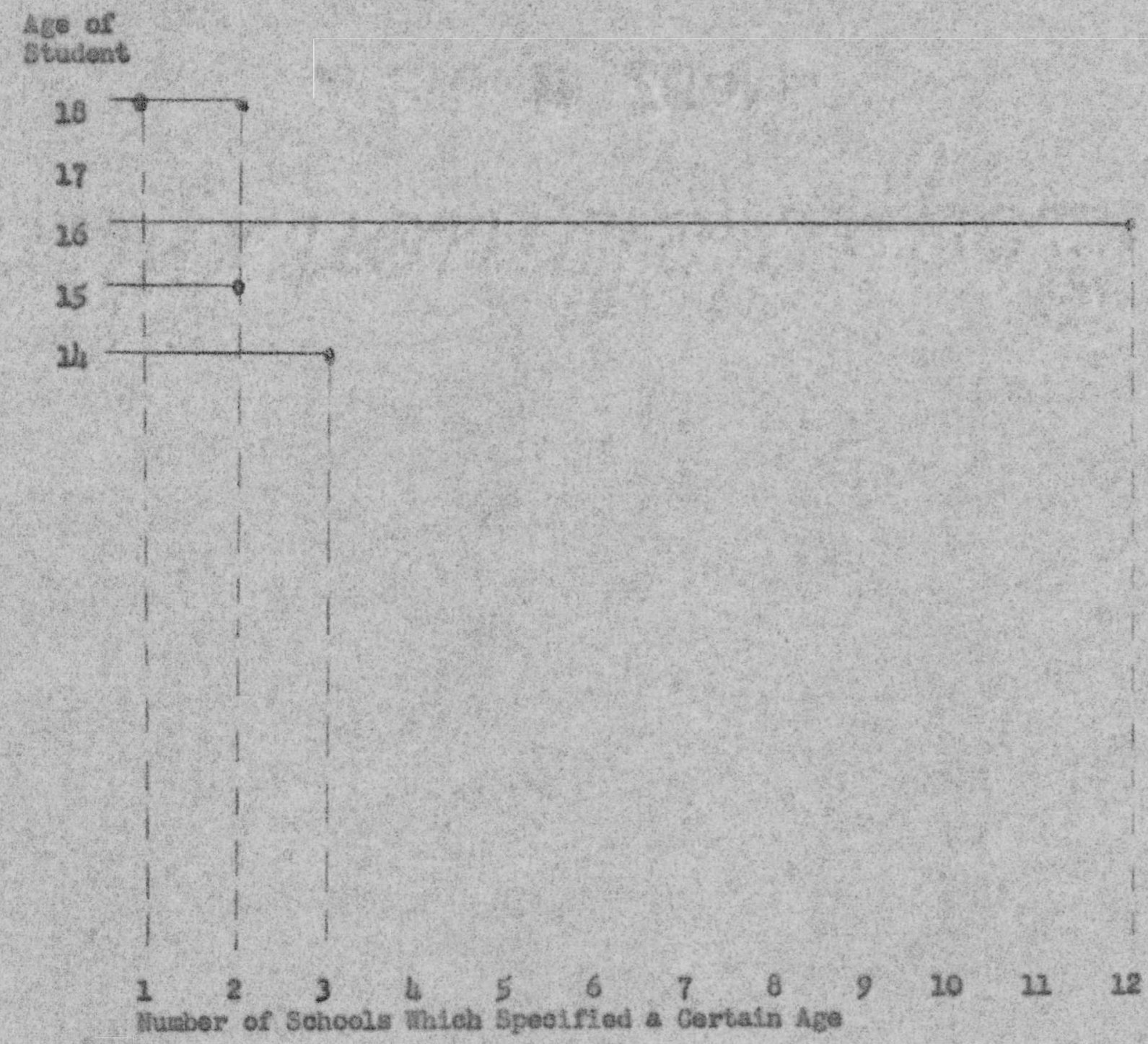

Fradre 20

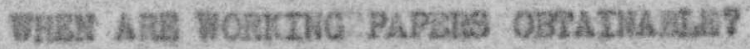




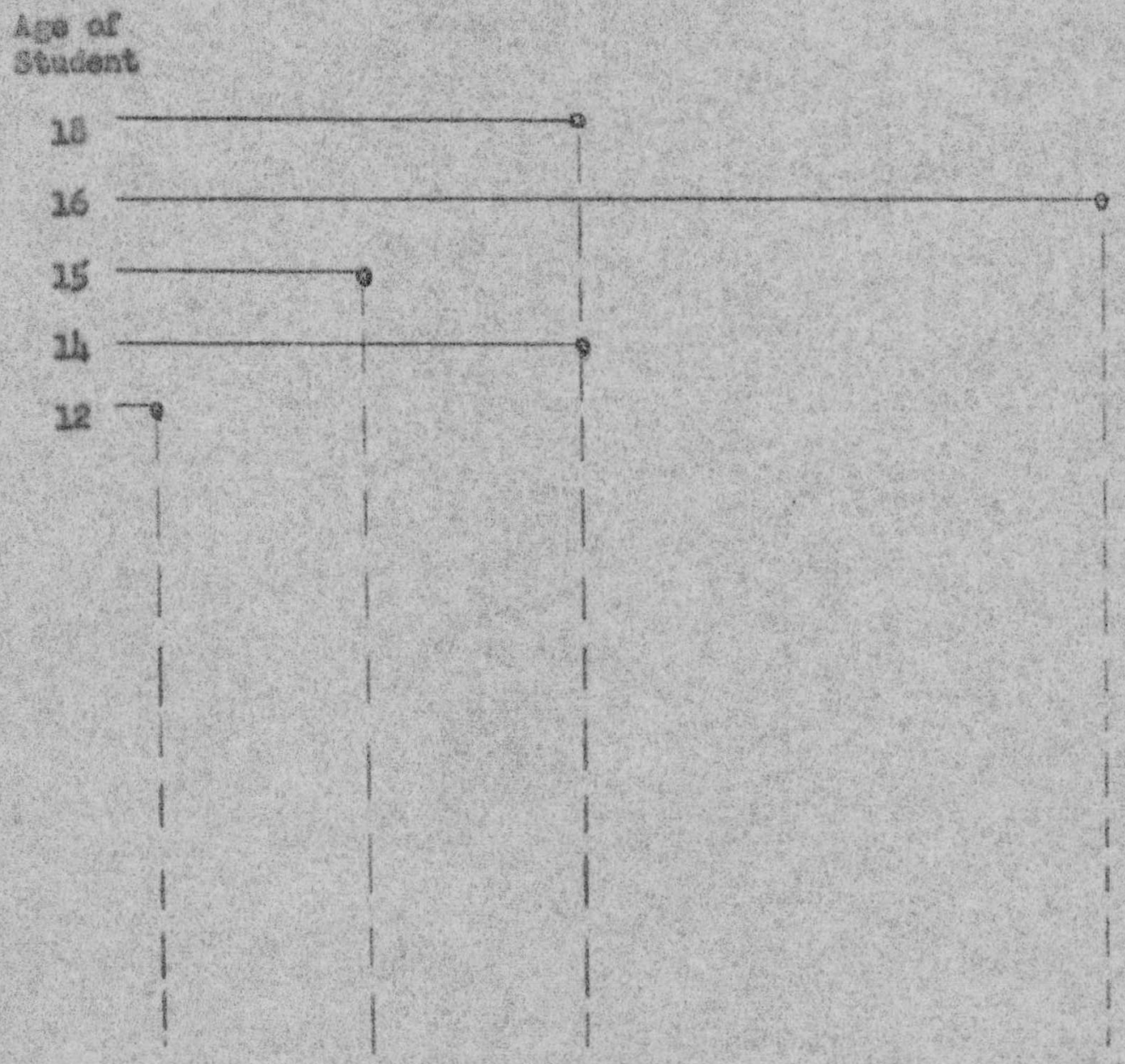

$\begin{array}{llllllllllll}2 & 2 & 3 & 4 & 5 & 6 & 7 & 8 & 9 & 10 & 11 & 12\end{array}$ Hunber of Schools which Specified an Age at mich students byy Run Farz Wachinexy

pravas 21

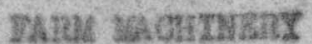


Age of

studont

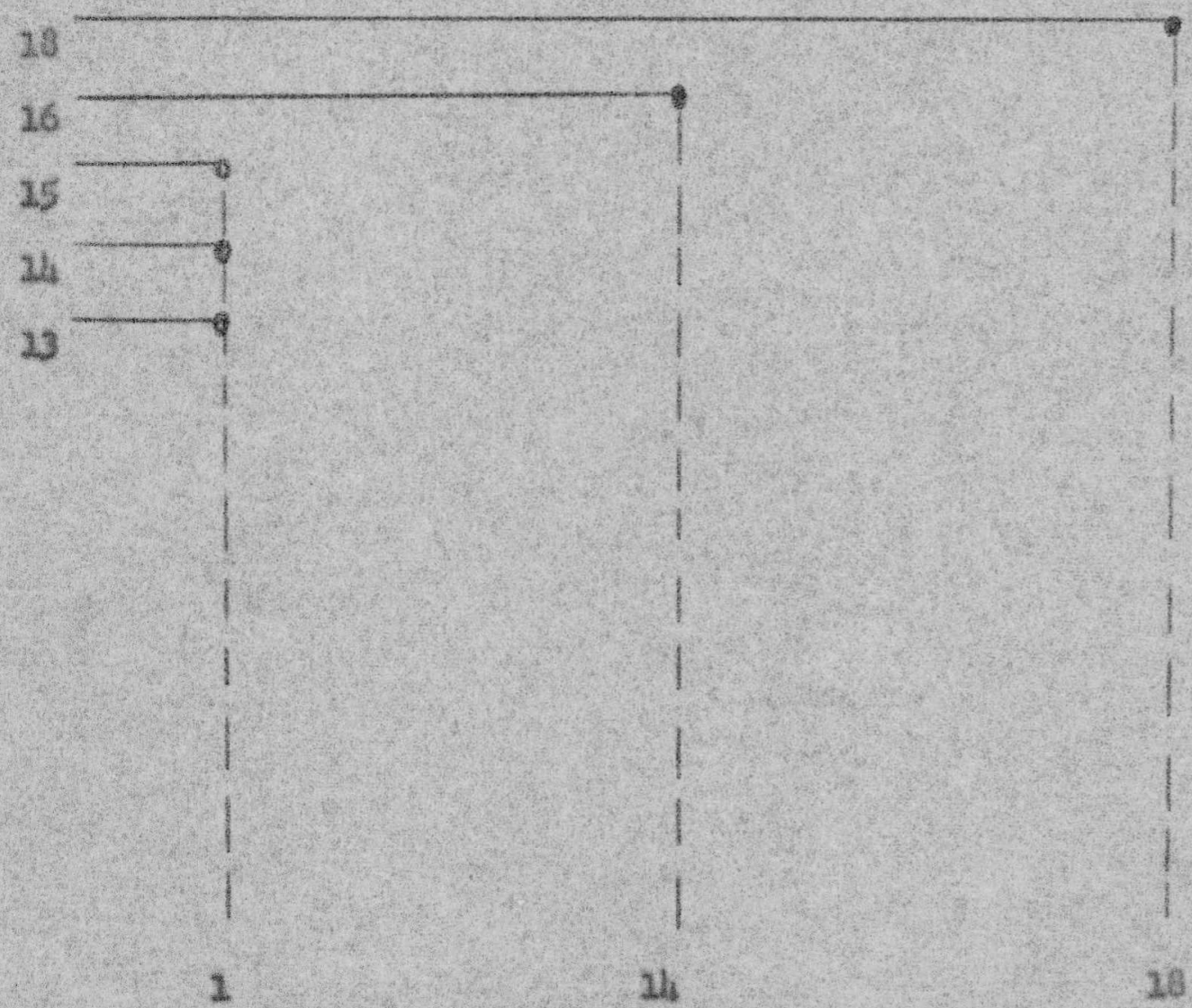

Wumber of Sehoole tho Expressed an Age at Mhteh Stulente Lay Operste Nor-agrieud tural Power liacbinesy

rxouns 22

pormen manminat 


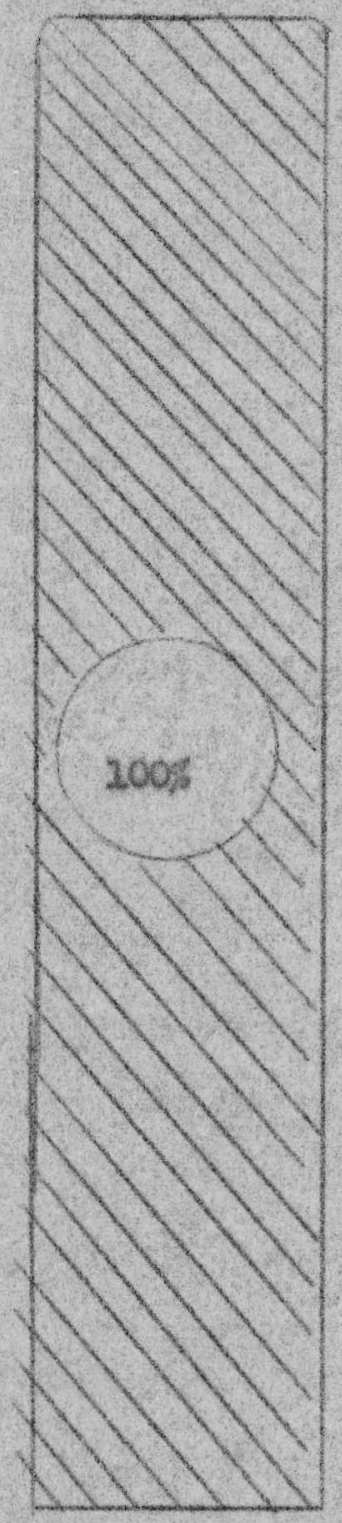

54. Reports

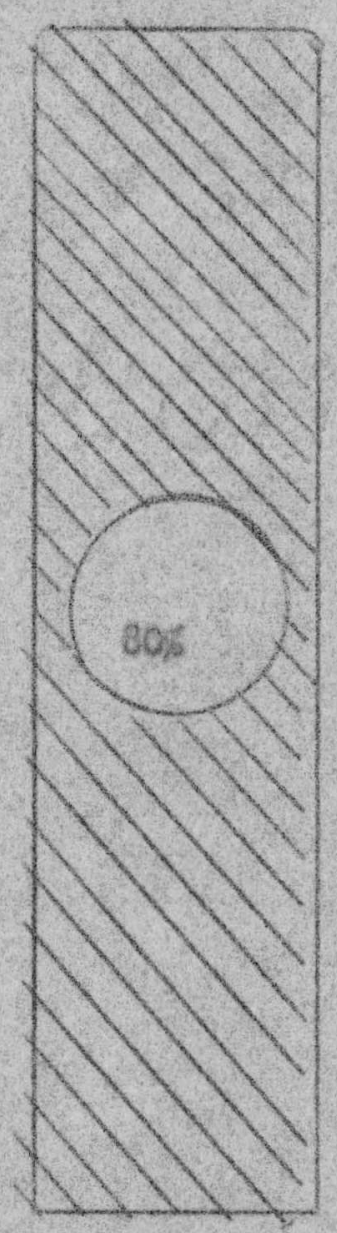

$43-105$
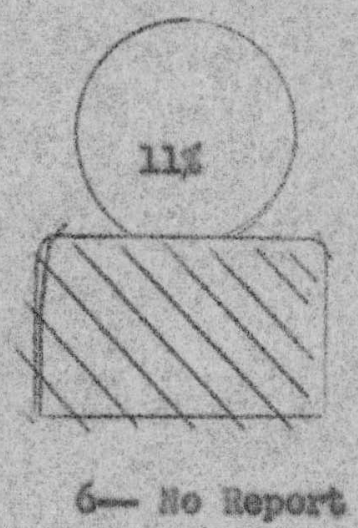

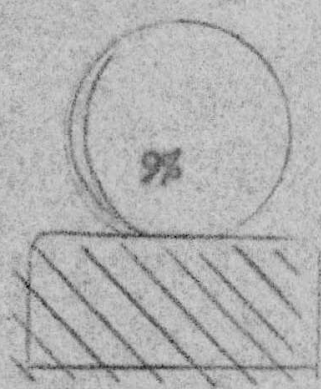

$5-110$

\section{Brava: 23}

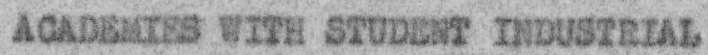
Acctover ThSURancs 


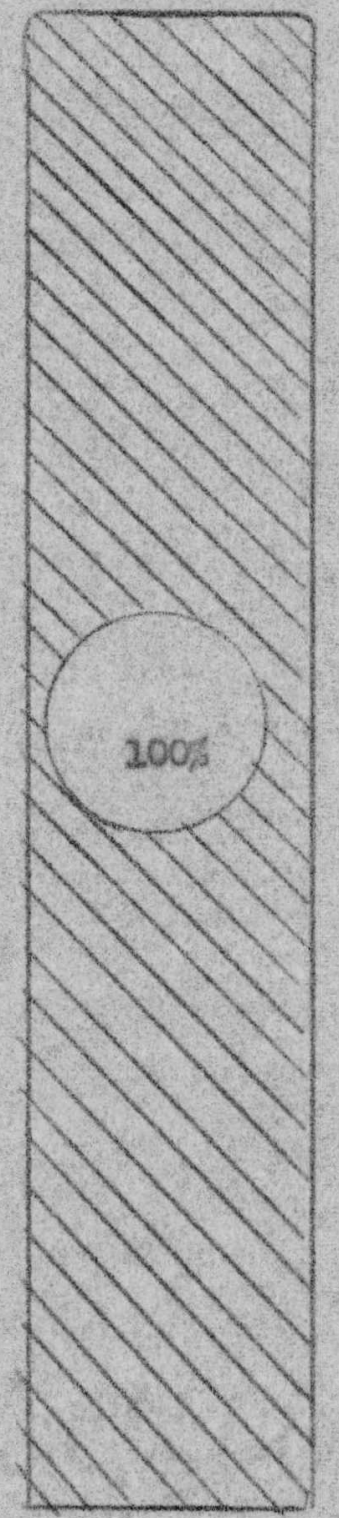

32 Boarding Sohools

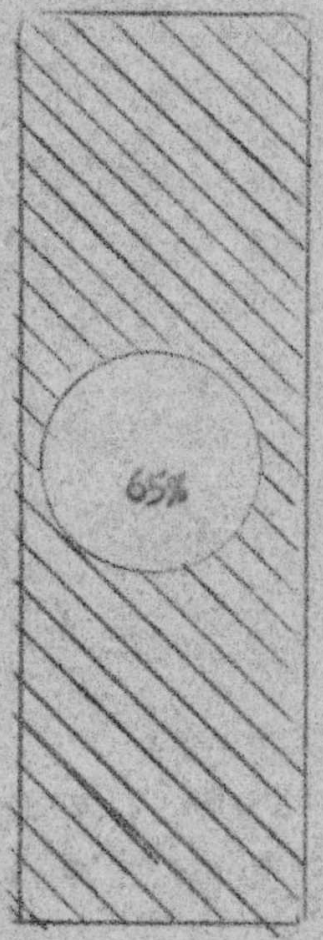

22-Tes

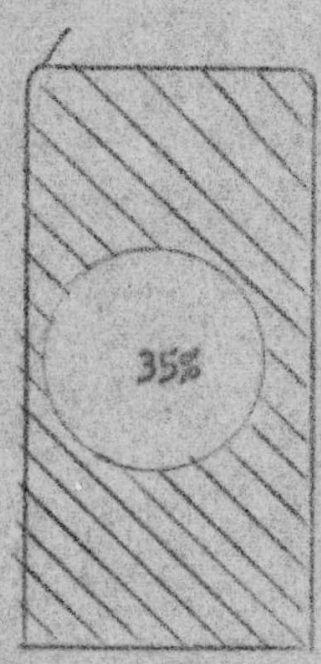

21-lio

\section{Niours 24}

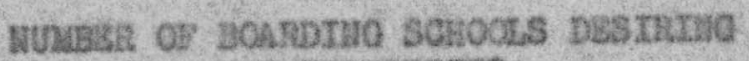
thin zubusmetrs 


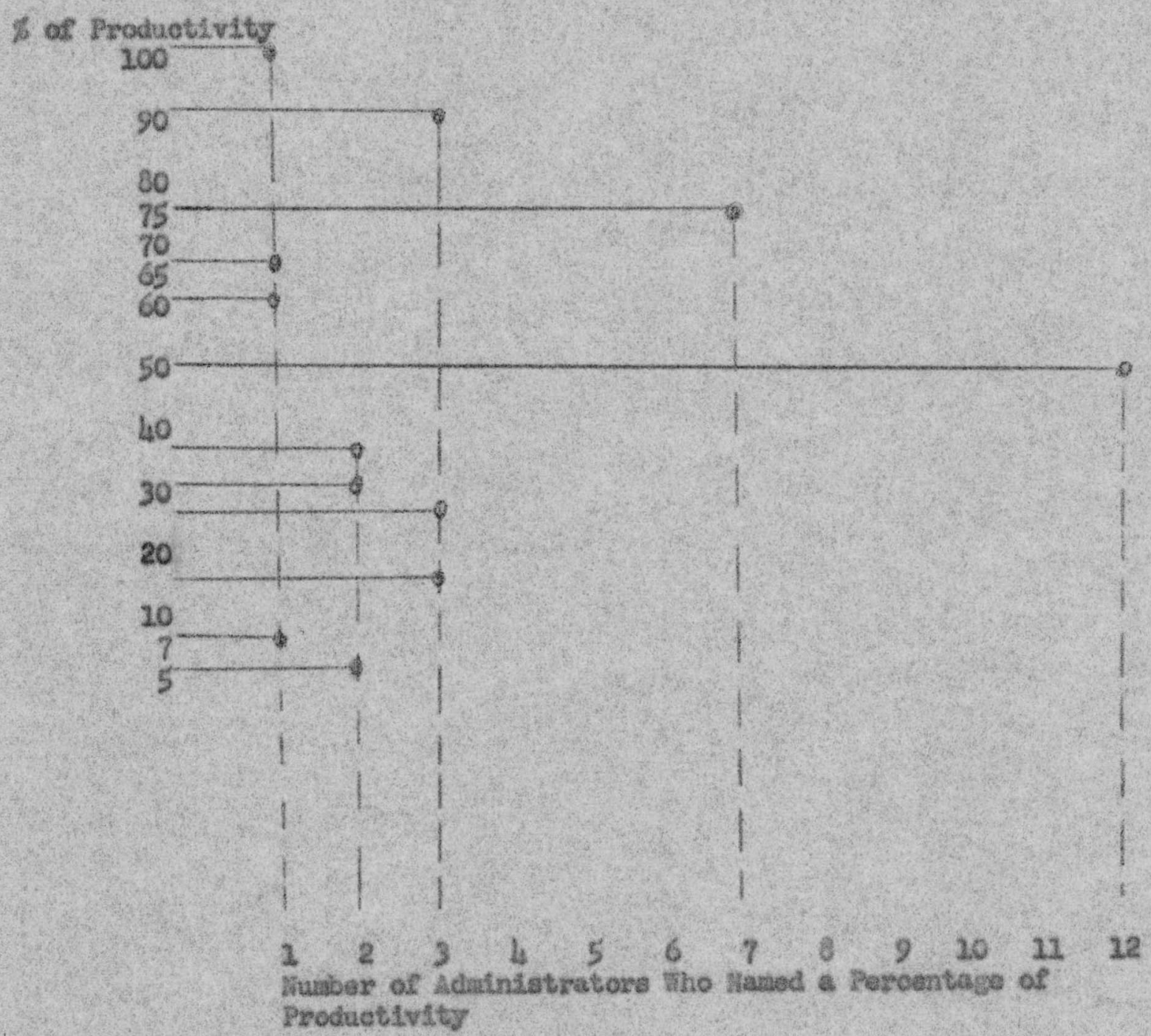

7rouns 25

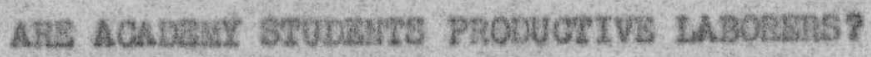




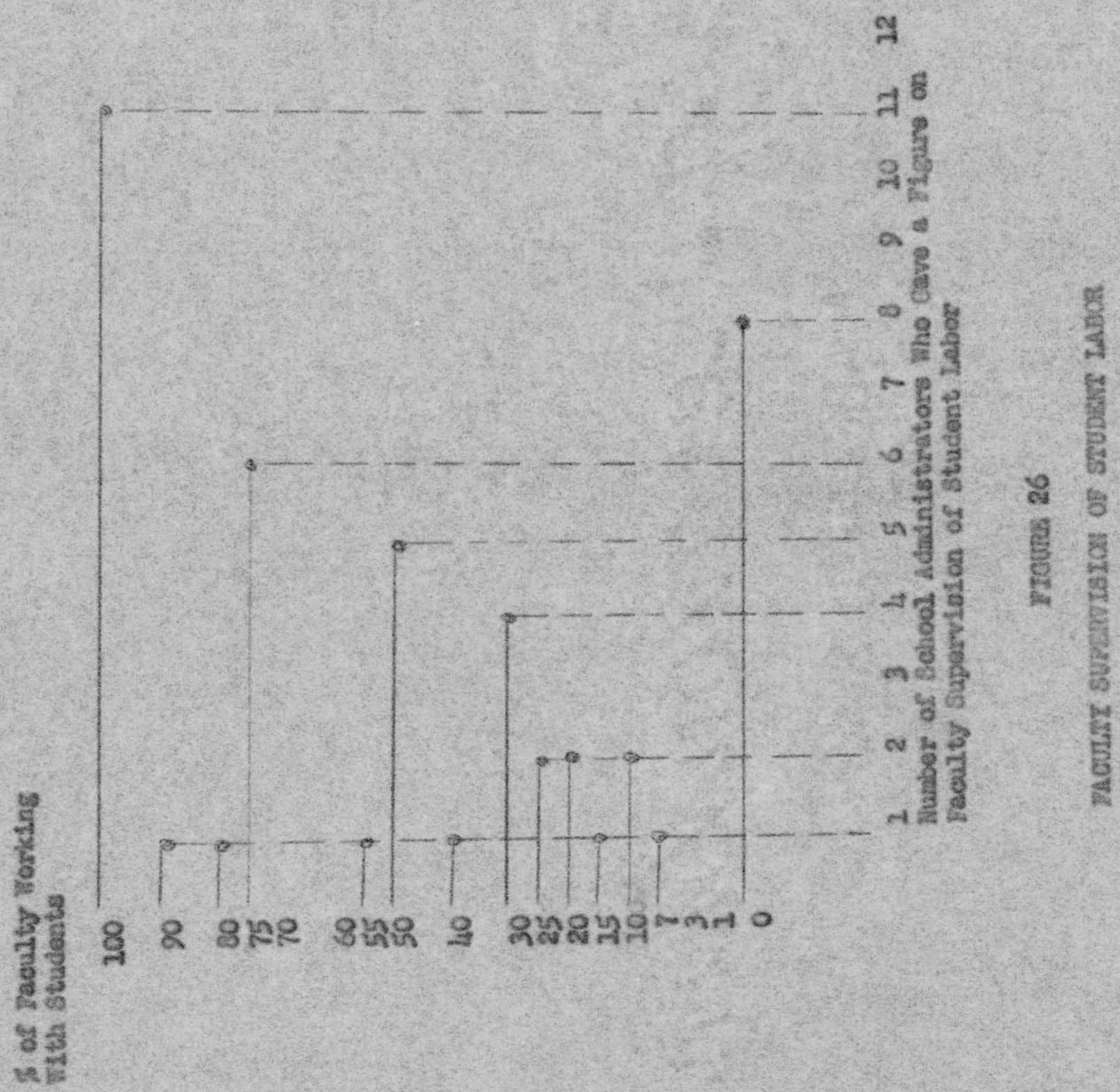




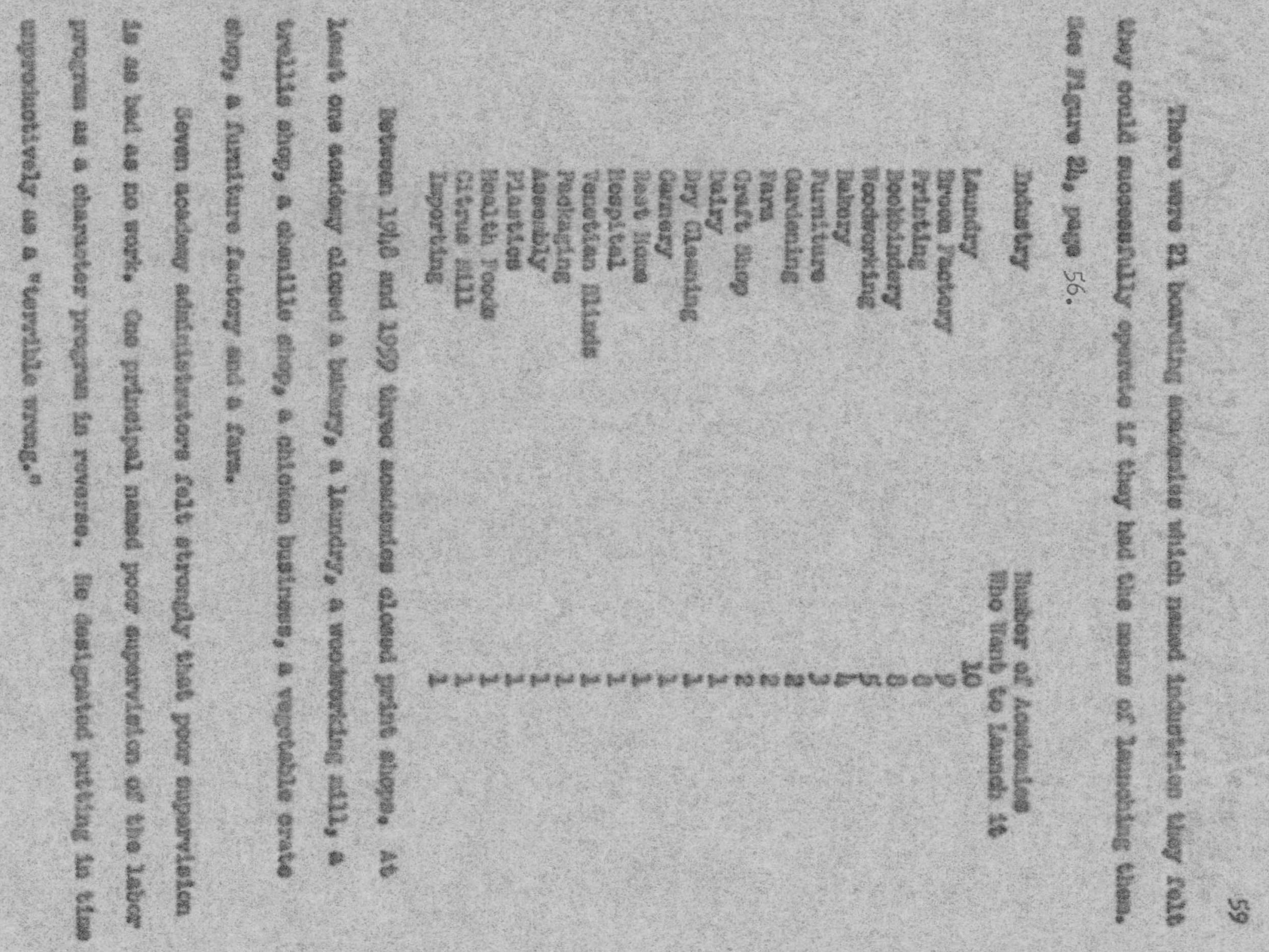


It was gelt by sone pxinolpale that there te too much saphasis placed on "earning" through stradent labor and not enough englaus is on "Mearning" froa the work-oxparience. See Figure 16, pace 50. Bork has not accouplished 1 ts end $1 f$ it is only a wans of paying bluls.

Host school adalnistaretore folt there was a definite relationship botwoen aotive labor and charadier developant. Such tralte as promptrness, dependubuity, Andastry, hardaity, initiative, hoaesty, and perseveranes wore Ireely alattted to be the cutcone of vell-supervised 2abort, See Figure 26 , pace 64. Sevaral, though no spociflo quection plin-polnted the area, advanced the optnicn that peorly suporvised labor

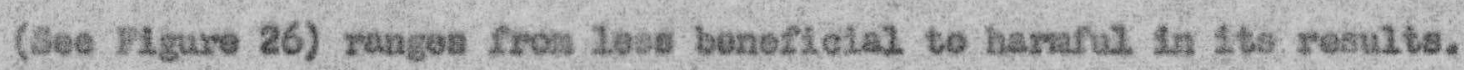
The following statesenter are taken directly fros thelr raporte.

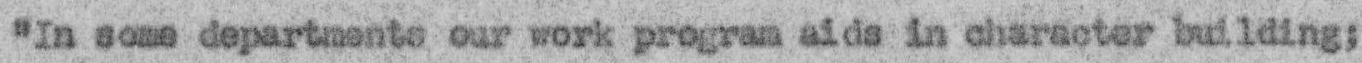
in others, due to inadequate euperviston 16 is 2 ess benorictal."

ate proper2y auporvisad and If it la effieiant, there le a bldt cerrelation botween student Iabor and charaoter bullding.

"I believe there is a close relationship between thes if one has eurricteat atars to give propor aupervielon."

"Properiy supervised It is the beot. Zoo often, howver, student 2abor is putting in time only. This is terribly wrong, "

This guestion broucht a largo nuiber (2h) of roplias, what 19 your understanding and objective coneerning the place of construetive manual work in the school prograd, partieudarly as it conecrne the montal, zoral, and soolal covelopment of the student?" 
A crose-secties of answers reveals the following opinicne.

There "mast be work In order to develop the three properly."

"The training of the land is as lngortant as the trainting of the haad-most Luportant."

Fere are trying to carzy out what is taught in the book Educatlen,"

"I beliove that construptive manual labor Ls absolutely an esaenthal elesont in education,"

"It belps in providine a rounded training for the adoleocento"

Fie belfove and taabh young people the valuable benatits of canual 1abor: Carietian echucation to the developnent of the phyotcal, kental, and the spiritual in the procese of Mvinge"

"It is a part of thair education if It is construetsve. WPA work Is unfortunates "

ng belleve I'n a sember of the old achool. It seess to no that a tro-br three-hour-per-day labor program is conducive to a nore cynatrical. developisat of the atudente"

"I belleve, if properly organ1eod, labor ean be a valuable medna of giving a student or helping a student, develop koral strvath, 1irting ble mental output, and aohseving a degree of soolaltastlon, $n$

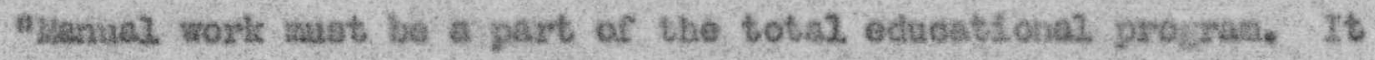
uralns the cht1d for responsiblistles he will encounter in saturity, Our

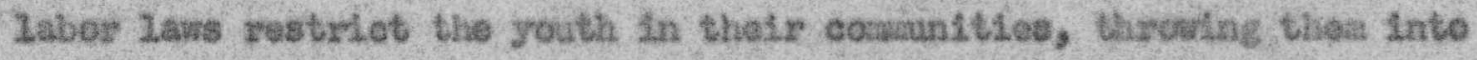
1dleness and onto the otreotst-s poor environant and tratninge. Our echools can change thie pletare for parent and youth. Inegfratioa gives we the plan." 


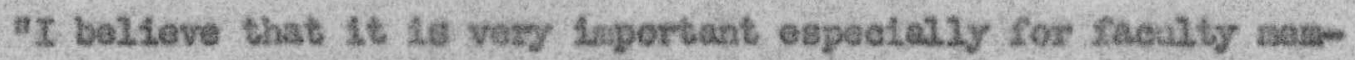
bora to work along with the otadents, It bullis repport, and osfers a good thas for unrestrained comecling. It is ons of the best opportunLttes to aseist in eharector development,"

af find it helps to stabilise the restlessness of youth by prom viding noeded physical exaroloe,"

"fianding toples as carafuliy as charseter holjo the atudeat in hla jobor to develog patlenco, creative satisiaction, healthru exerolso, and exdiurting coupensetion,"

"It conoems the total dovelopaent of the student. Lexulng to worti and to respeot the elspaty of labor is an lntegral part of educatlon. Lealch, vigor, and seli-disolpline aro also Involved,"

Cniy 235 of the studente employed in the 23 major indiastries. offering employnent on Seventh-day Adventist acadeay carprises rork out-

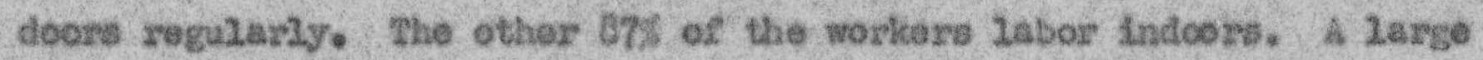
ehare of then are seaders, secrotarlos, tolephone oparstors, ote, Thie woans that they get no plystcal exarelae or ralease from eye-strutn cluring thelr workdng hourd.

Any employnont woul auporvised and well done bulles ebaractar. However, that work which is ective, especially in the outmof-icors, builde vigorous hoalth as woll as charecter. 


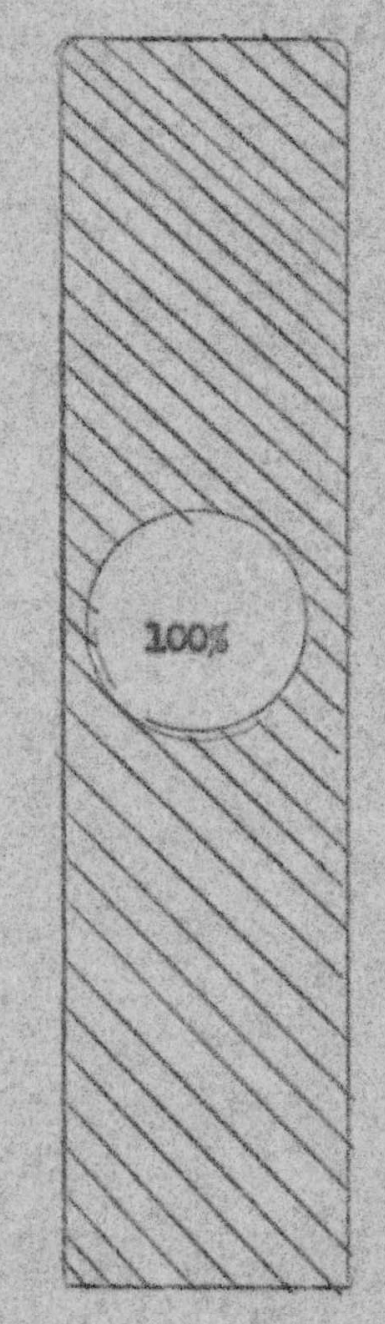

4,777 Imployed in 24 kajor Industries

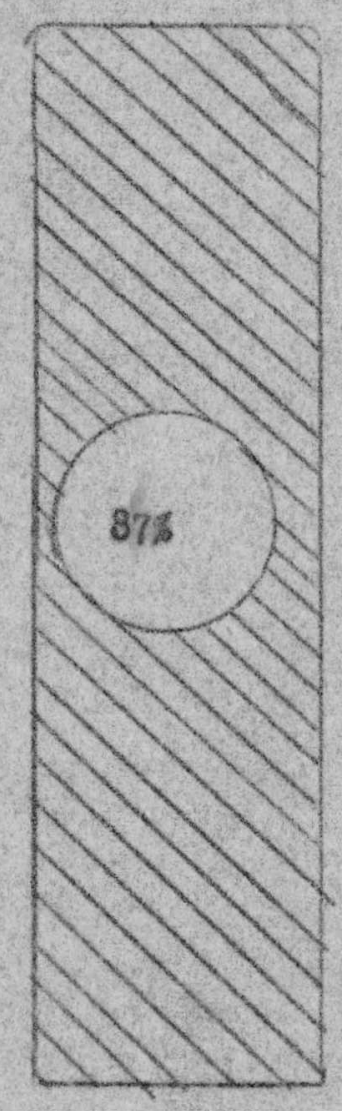

\section{4, 223 Baployed Indoovs}

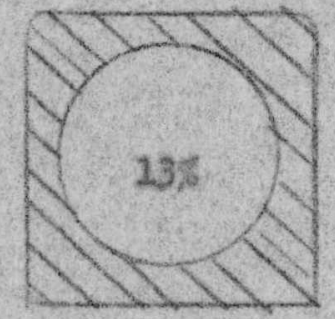

65h. 1taploged autaloors

\section{Ftaurs 27}

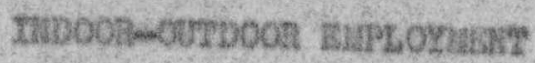




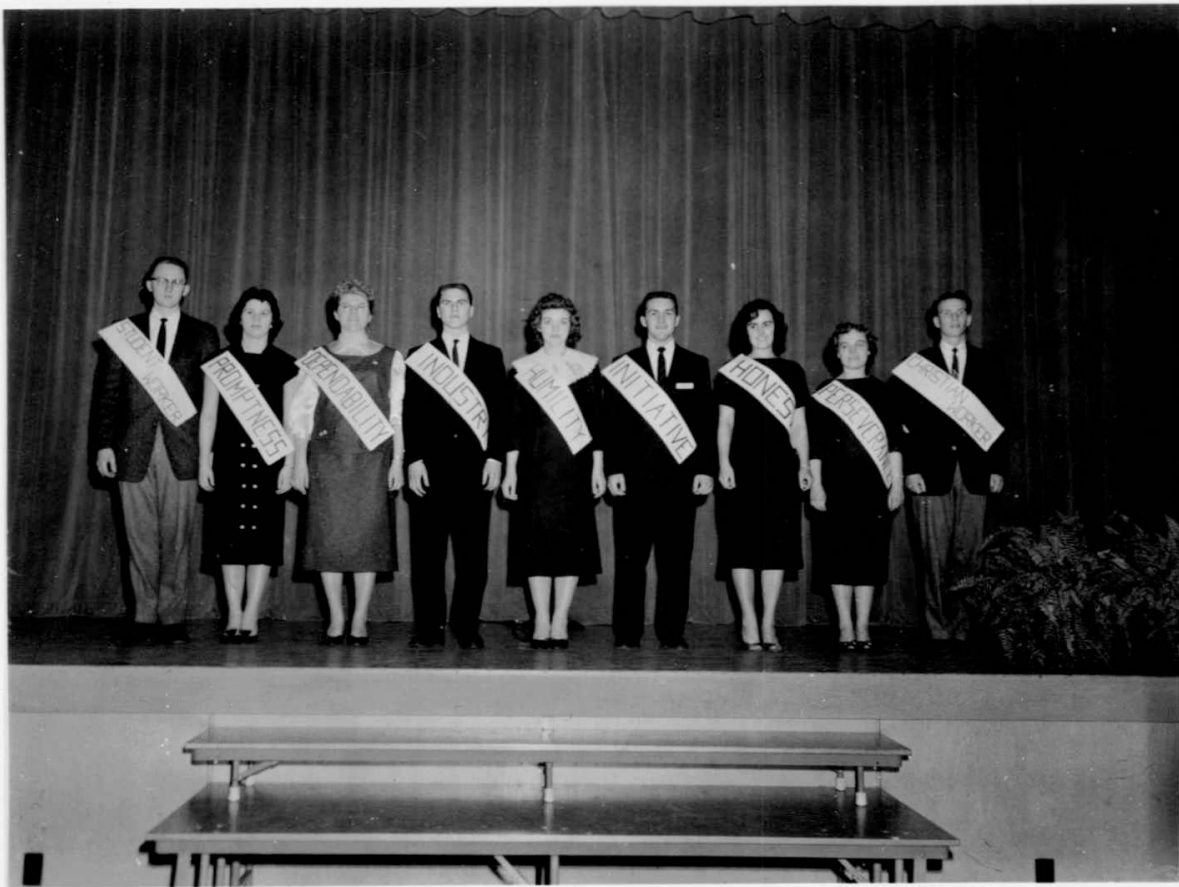

Fravian 28

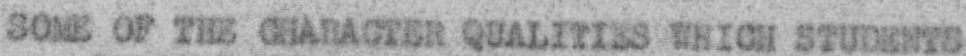

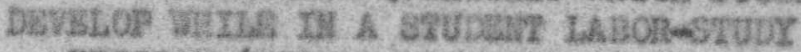

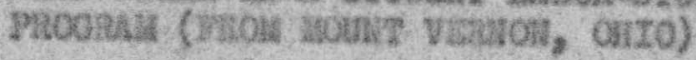




\section{GANTER $\vee$}

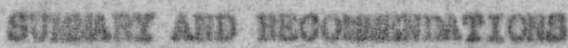

\section{Sumsagy:}

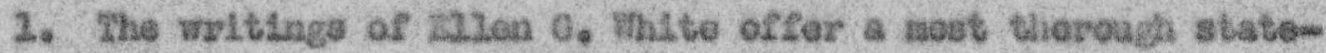
mant and esralote philoscply of balanoe in oducation;

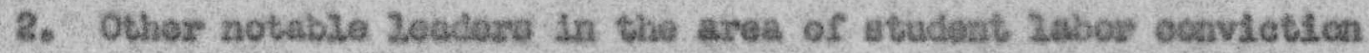

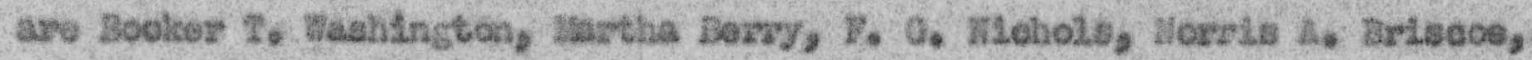

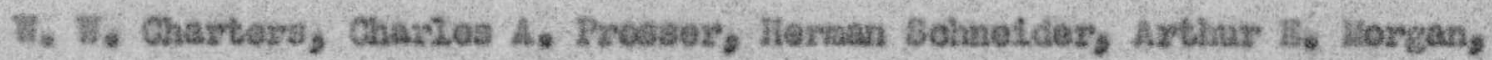
and Wra he Nudson.

3. Several sehoola bove tried excollent workestucly progranis

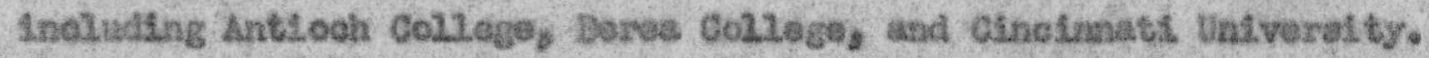

L. Fron esorg the 75 sentor eculemies in the Horth Averican

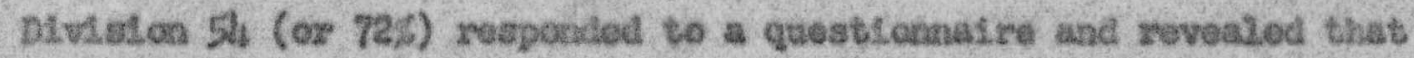
olitty por oant of the Soventh-dey Adventige acedentes are bourthes

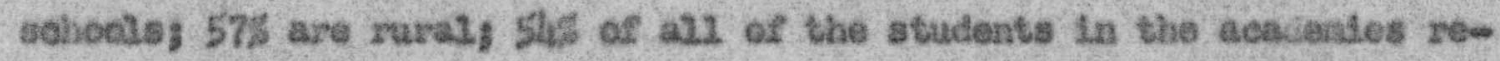
porting are exploged at the aceilent.

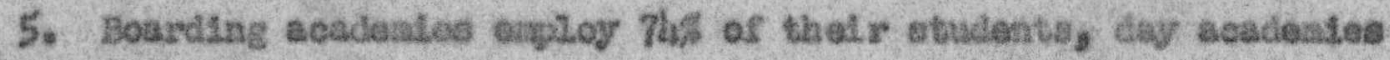
27\%:

6. of 8,800 atudeats, 4,777 , or $545_{,}$are erployed in 23 wervicea os Indastries, 950 in cafoterias and 960 in axatntendnce.

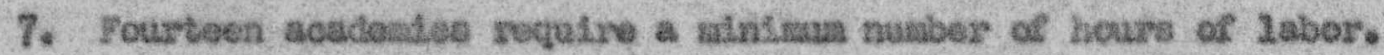

B. Lesdory adiatndstrators $(65 \%)$ are not eathesied with their Labor programe. 
9. Acadery adalntetrators (755) do aot feel that thedy sohoole roseh the Bevontheday Advontlet otandard in the atudy-ilibor progreas, 10. School adtalnietraters (92s) seel that there is a definite relatlonship betwoen a woll-eupervised labor progrem and devoloplng a vell-meusuded charseter.

11. Of the ecadoales in the Forth Areriean BiviaLon, $\cos$ have sehool faris.

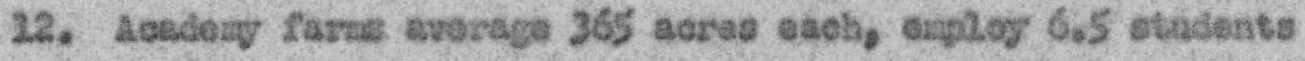
each, and $20 e t 56,210,26$ aach (averace) during 2956,

13. only 9 out of 32 sama pay rinanotal1y.

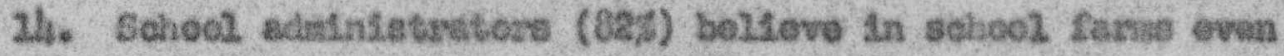
though they do not at prosent pay finaneialy.

25. In the opinton of the prinetpala 50 s of the ceoleateo offer a belanoed vorkestudy prograbs.

26. Botrding sebicole (65\%) are beelding for new industrless

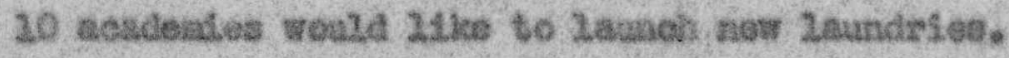

27. Noet of the sehool alnthistrators feel that 50 ; to 758 of the studenta are produotive 2aboreze if proper2y auporvised,

18. Beven acalentes have $200 \%$ of the faculty aeststing in the otudonk-wortk prograks.

19. In spite of coussel that all stucents and faoulty should spend sone tiras in the out-aifedoors das $2 y, 675$ of als students euployed at acadealas aork indoors. 
20. Iroa the best eothates avallable 1t appeare that not more than 655 of the ecadery etacionts have systeanatle exployment (Vinter and Surasar) eithos at hose, school, or in the cosaunity. Reconandations fos Ifreroving the warl-atudy progras. The recoarch sunuartsed in Chegter IV Lndicatea clearly Wist thero are defind te arvas in which Seventheday Adven tist acadeigy adnintetrutors oculd Inprove the work-othity progrant.

1. That a restudy of tho mase of vital counsel on worte in ectucathen EIvon to the Sevanth-day Advantiat people be eneouraged.

2. That Intornodtate echools and day soadontes glve stady to Inplesantling a plan to eee that sach student has a wozk progrea in the bone, sehool, and conmuntt.

3. Ihat bearting acadentes stady seztouely s balazeed plan of worth-etudy for thatr antiro etadent body and facusty.

4. That the Beventh-day Adventiat echioole pat corv atrees on abeful Iabor Lnstead of cospothtive sports.

5. That a mholosone attitude tomard manual jabor be sado a more Latoeral part of Soventh-day deventist eduoatlon.

6. That more otroes be gtven to learning usedus trades,

7. That a work-sthdy centered eonference of edicatore be called.

0. That wherever pessible the taachers and stadents werts together.

9. That study be eivon to getting nore of the otudente out into

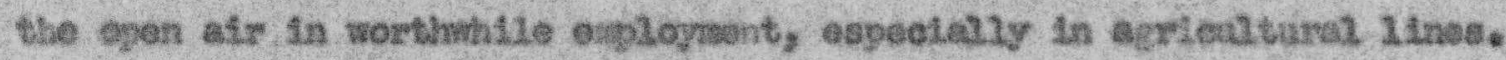
20. That the valus of sehool fara be not enttrely masoured by the balance ahoet. 


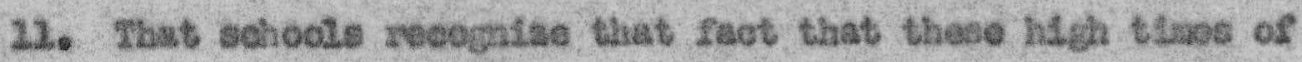
prosportty w211 not alvays proval1, and that thoy plen sou a zargor

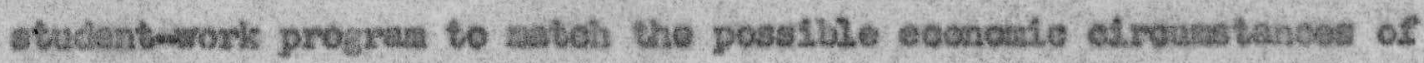
the atare.

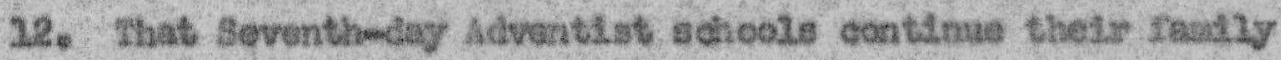
concogt end that they andosvor to be nore self-contatrind is sood prodisctlos, procoselng, Rroos las, and storago.

13. That the teachorwtratring In cur colloges bo plamed to produce a practical rorihetudy ecacopt in the teachere of the futuro.

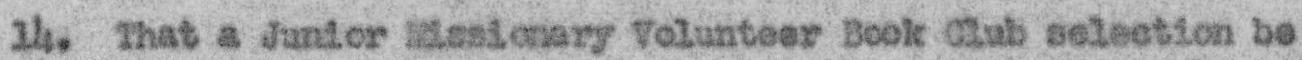
witten strossing the werlts of a worli-study program.

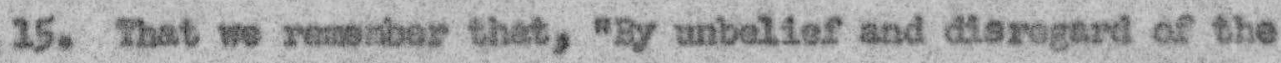
Lord's diroetscos, the Trrtalites surrounded thenselves wlth terptablens Shat for had powar to ratists th $^{3}$

Areas for Wurther Stuhy * Exgortence, eounsel, and gonviction aro vory elear as to the importance of a work-while-studying progrus . 5uraly there is auch to 2 earz and to put into probtioe in thle aren. Euggesthone for furbler study are varled.

2. A stady of the woric hablts of all stacients whe are corlous dLectplinary problens in the Seventh-day Advenulst scacievies of Iorth Anorlas.

2. A study lnto hos to tiplonent a work promres lor charch schoole, Lnternadiate seivools, and day acadastes.

3. A study of the sclalastic attainnonte of studeate who work 25s or more of thels way in comartson to those who do not worle at al2.

Iniea O. Whitie, Bducaulon, D. LS. 
4. A study into the tratning and baotzround of the els truly outatanding stucients on esch acadony caragus in any glven sobool jear.

5. A strady tnte the atbitudes and work habitis of stutiente in Seventhoday hdvent1at schools who give no evidence of convervion,

6. A study linto the lublts of henesty, 2oyalW, and falroplay, and Its ralationehtp to good supervialon, in atudent labor.

7. A study conedralng the trainisg of teschers in the areas of practleal work-obudy phlisosogty,

8. A strdy of voeational training for stulente for whon the acaciony neans a tomainal ectueaulion.

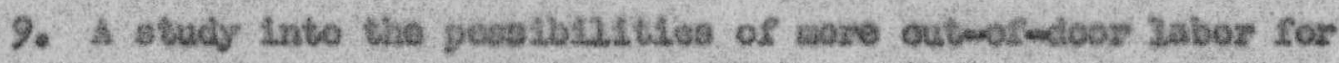
both sexes.

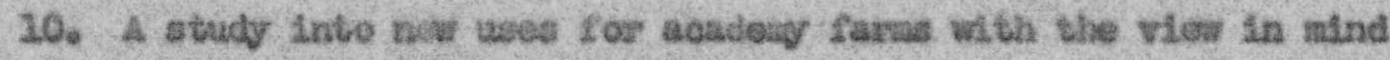
of effozing a nowe balaneod edheation. 



\section{BIPL, TOCRAPRX}

Antloeh College Bullotin, Yollow Springs, Ohlo, June 1957. 224 pp.

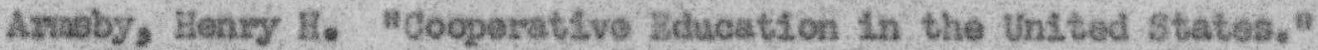

Eashingtoa: V. S, Dept, of Health, Fel fare, and Betueatlos, Wash. 21,

D. C. Clroular No. 463 , Eov, 1955. $7 \mathrm{ppe}$

- Cooperstive Ecuestion in the United States, Nushingtons

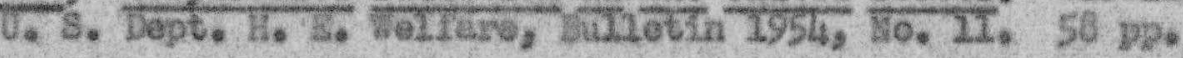

Berea College Du2lotin. Bores, Nontucig. 2958-59. 125 pp.

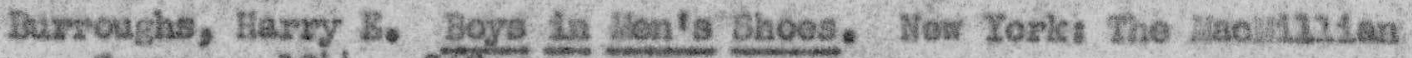
Coupary, 1944. 362 p.

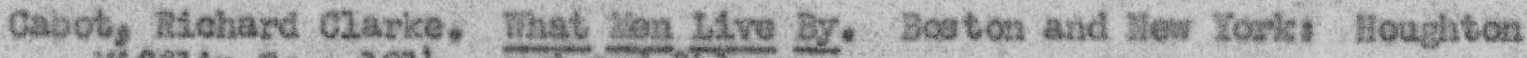

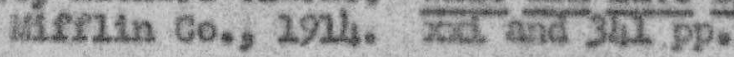

Gedy, Lartion B. The Edveation That Zducates, Baw Yorks Noadng H. Levoll Co.s. 2937. 254 DP.

Gaerters, W. W. The Tosching of TCeals. New Xorks the Malumian Co., 2929. $350 \mathrm{pD}$.

Chize Labor Buletin No, 101, A Cutde to Chill-2abor Provistons.

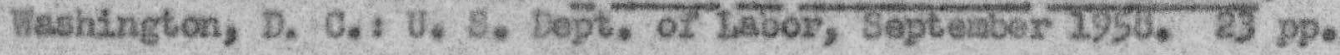

Day, Bethis The Littile Professor of Plnoy Toods. Nes Ioxks Juzian Hessner, Inc. 1956, $109 \mathrm{Dp}$.

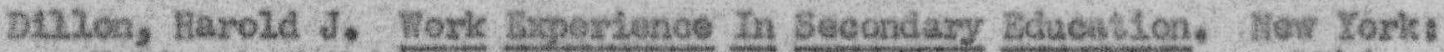

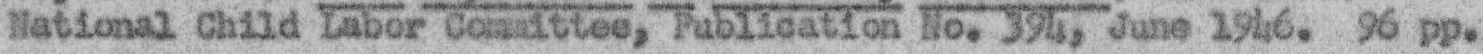

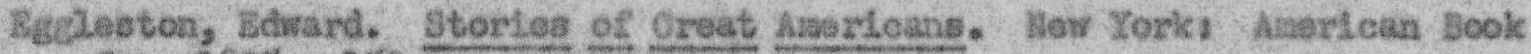
C0., 1695. 159 pp.

Past, Forard. Goothals and the Fanana Ganal, New Lorki JuXlarr Lesener, inc., 1942. $223 \mathrm{pD}$.

Ierritere, Adolph. The Aotivily Sohool. Nev Yorks The Joha Dey Company, 1928. $308 \mathrm{pp}$.

0121, krie. Foris and Culture, Nemport, R. I.: Jobn Stevons, 29 Thanes $36 ., 1937.25 \mathrm{pD}$.

Cold, 141 ton J., Ed, D, Working to Loarn. Ner Yorks 2eacherto College, Colubia Universtty, 1052. 279 pp. 


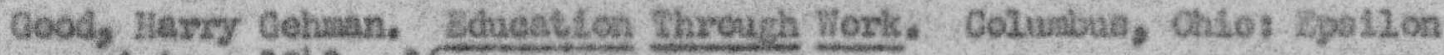
Di tan, 29l3. $26 \mathrm{pp}$

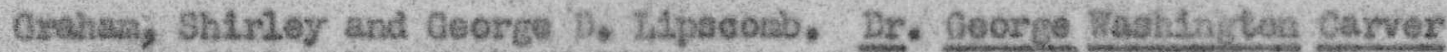

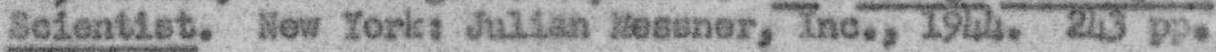

Hercas, Alexander R. Why Uon Worl., Stanford, Calif, I Stansond Ualversity Preas, 1948. T197 p\%"

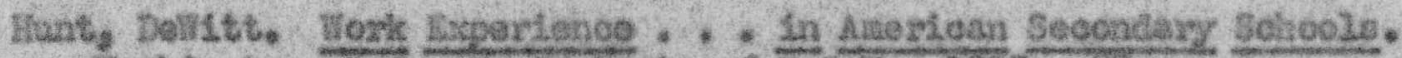

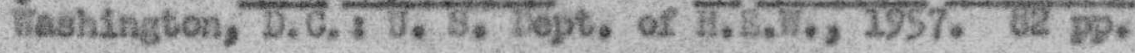

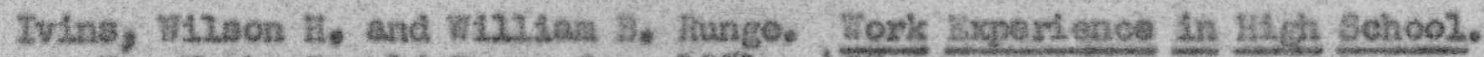
Hev Iorks Bonald Prees Cos, 1951. 490 pp.

Joumal of zrue Ecueation. Washington, D, O, , Nevien and Lerald Tublish-

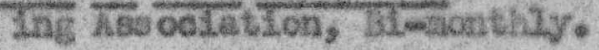

trano, Hartete $\%$. Hiracle In The Hountalne. New York: Dotbleday \& Co. ind., $1956.310 \mathrm{pp}$.

Laban, Rudole Van. Effort. Londont lacdonsald \& Evane, 1947. $88 \mathrm{pp.}$

Iable, Bawiliton wright, Rasays on Eork and Gulture. Low Zorits Dodd, liand and Conpany, $1824,247 \mathrm{pp}$.

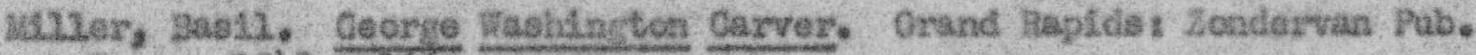
Etouse, 1943, $160 \mathrm{pg}$

Mebraskice State Department of Labor. Nebragia taboe Lawa. 3957.39 pp.

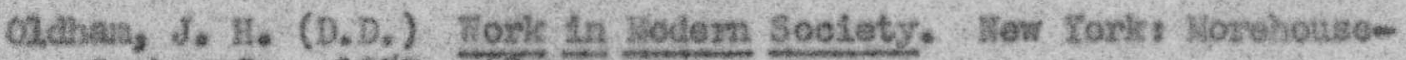
Gorhan Cov, 2.950. $62 \mathrm{pp}$.

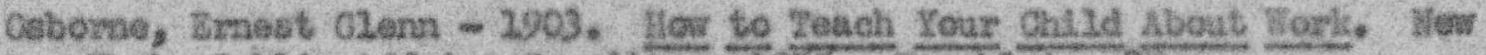

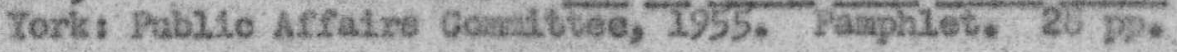

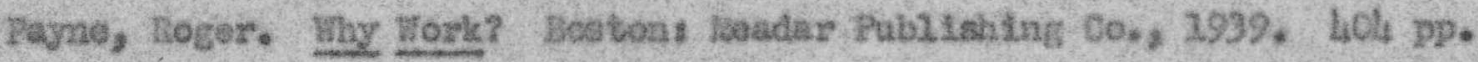

Payot, Jules. W112-powor and York. Ner Yorks Funk \& Wagnalis Co*, 1922. 422 pp.

Plus, S. F, Faoul. In Fralse of Work. Westalnster, Whos The thewan Press, 1952. 10I pp.

Frosser, Charles A, and Oharles R, Allen, Have We Rept the Ratth?

New Iork: The Century Gon, 3929. 429 pp. 
Mohardson, Goorgo thann. The Gospel of Work, Palo Rlto, Calirornla:

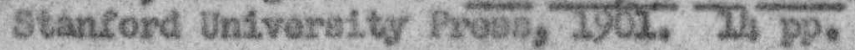

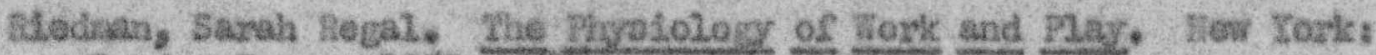
Dryden Prese, 2950, Jut pe*

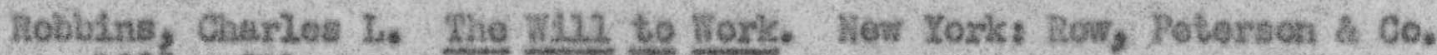
1926. 211 pp.

Sayers, Dorothy Leigh, Bhy Eork? Londont Wetheun \& Co, Lit., 29L2. $24 \mathrm{pp}$.

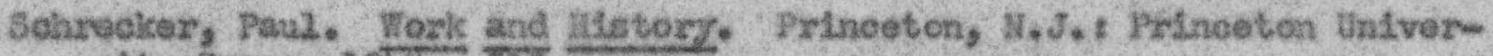
sity Prese, 19486 3IS Pp*

Seyfert, Warren C. and Pavi A, Rohaus. Nork Sygertence In Educetion.

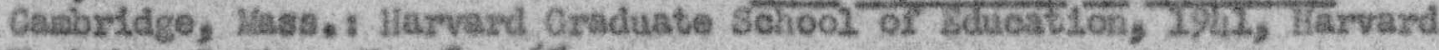
Workehop Series, $110,2.65$ pp.

Spalatng, A. ซ. Csptains of the Host. Fashington, D, G, t Revlen and Merald Publishing Assodtation, 1944 , 662 pp.

- Christig Last LorLon, Washagton, D, O, 1 Reviow and Eerald

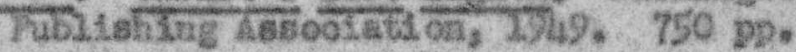

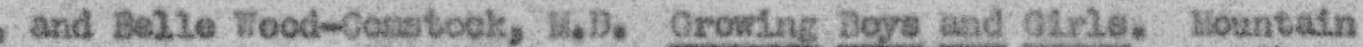

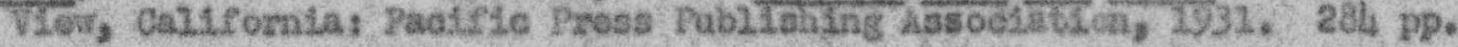

Steere, Douglas v. Fork and ConteiplatLon. Mew Yorks Barper e Brothers, 3957. $245 \mathrm{pp}$.

TH1 her, Adriano, Work, That it llas Jeant Through the Ages. Now Yorks Earcourt, arace and congery, $2930.225 \mathrm{DP}$.

Viteles, Horris S. The Bolence of Work. Ner Torkt W. W. Nortich \& Co., trie., 1934. $424 \mathrm{~m}$.

Vocational Divialon Bulietin Mo. 260. Distributive Solucation Sertes Ito.

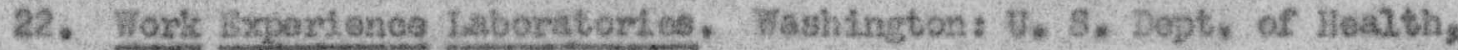
Equeation, and Worraro, I9 ppo

waohington, Bocker 3. Iy tarrer Education. New Yorkt Doubleday, Page \& 60*, 1913. $313 \mathrm{pp}$.

${ }_{302}{ }^{4}, 6 \frac{10}{p p}$ 


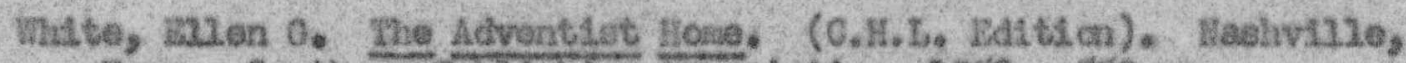

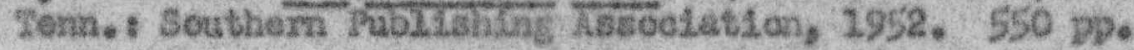

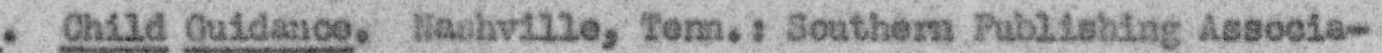
घTos, 1954. $570 \mathrm{pD}$

- Ohrist's Objeot Zoseorid. (C.H.H. Eattion) Washington, D, C, ,

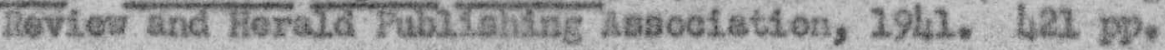

- Counsole to Parants, Feaghers and Stadents. Hountaln Vies,

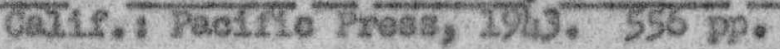

- The Dealre of Ages. Lountaln VIen, Callf, Peotese Pross Fubriahting Association, 1240. $835 \mathrm{pp}$.

- Early Fritinge, Washington, D.C.: Review and tierald PabliehMng Associavion, 194h. $295 \mathrm{pp}$.

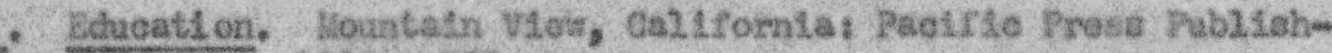
Lng Assodxtation, 1939. 309 pp.

- Pandanentals of Caristien LducatLon. Habhvilie, Ieni, :

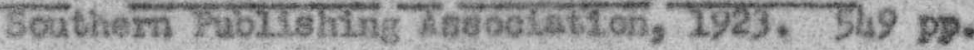

- Patriarche and Prophets. Nountain VLem, Calsf, Peclele Preas

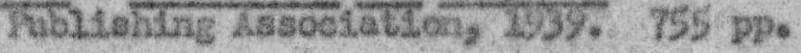

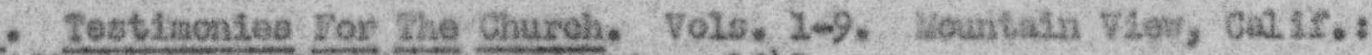
Fadifle Fress pubtions as asciation, 1941.

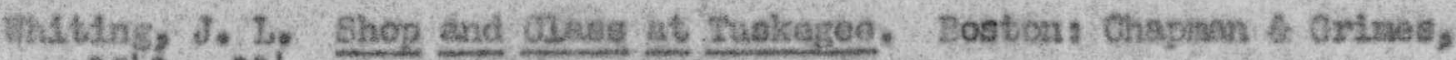
194., $124 \mathrm{p}$

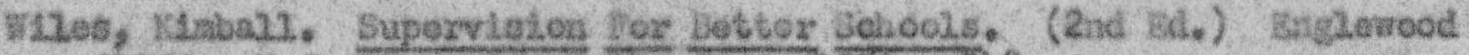
cistrs, NoJ, : Frentice-lall, mo,s 1956. 340, pp*

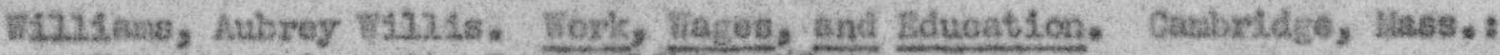
llarvard Univeralty Prosi, $1910.57 \mathrm{pp}$.

W11tse, Arthar Jr. She Abudant Life. Ana Arbor, Ulikt hio Am Arbor Rross, 1937. $16 \mathrm{pp}$. 
APPEWDTX A

APTEIDIX B

APPLXDTX C 
APPLIDTX A

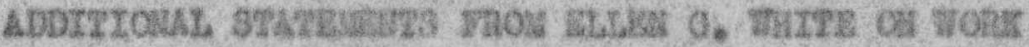

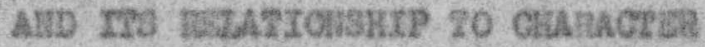

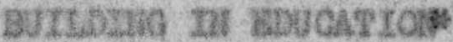

The worth of such tralning is not appreciated. There is an intiaate relation between the ritnd and the body, and in orter to reach a

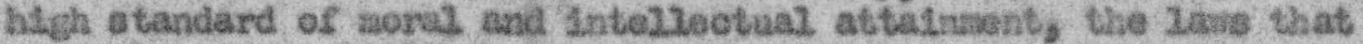
centrol our physieal bolng rast be beeded. To scoure a strong, wall balanced charaoter, both the abntal and the phyaloal porers aust be exarolsad and developed. That atudy ean be wore lyostant for the young than that whtei breato of this wondexhus organtes that cod has cowesteted to us, and of the laws by which 1t way be proserved in health?

Let the youth be led to understand the object of their ervation, to honor Cod, and bless thelr Iellow-neny let thes seo the tander Love whiloh the Father In hosven has manlfested toward therh, and the high destiny for which the disolpline of this 2180 is to propare thesh, - the dignity and honos to which they are ealled, oven to becono the sons of $\mathrm{Cod}$, -and thousands would turn with centeapt and Loathing frosi the low and selfish alna and the frivalous ploasures that have hitherto engrosesd then. They would leazm to hate sin, and to shun 16, not naroly sros hope of reward or fosm of pratshient, but froi a sense of 1 te inherent baseness, -because 16 would bo a degroding of thely codeglven powers, a stain upon thelr codHike mashood.

Cod does not bid the youth to be 2ess acpiring. The elanents of charactor that salco a wan succesaflu and honored cucus mon, the Invprosstble desire for ana greator good, the sndomitabio

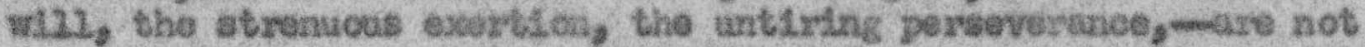
to be erushed out. By the grace of cod they are to be dintovted to

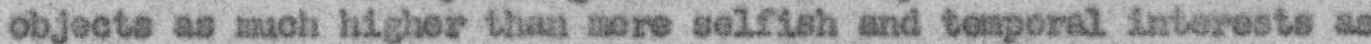
the heavens are higher than the earth. And the edscalion began in

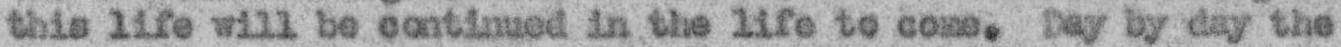
wonderftal works of cod, the evidenees of hie wiodoe and yeroy in eroating and custalining the universe, the Lrifinite ajstory of love and wiedcas in the plan of rodonotion, will open to the mind in new beauty. 'Sye hath not scen, nor eas heard, netther have ontered Into the hoart of mang, the things which ood hath properod for thea

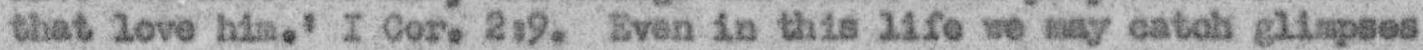

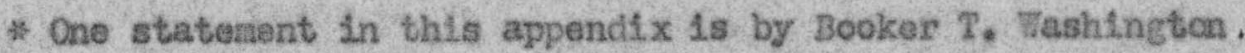


of His prosence, and nay taste the Joy of comsunion with hotven; but the fullinose of Lts Jgy and bleasing w113 be resched in the horearter. Sternity alooe oan reveal the gloricus destiny to which sen, rostored to cod's insige, nay attain, ${ }^{2}$

The Lord's purposes are not the purposes of nen. He did not design that man should Live in Ldleness. In the begivitng De eroated aas a gentlenang but though rich in all that the owor of the undverse could supply, Adan was not to be 1dle. Wo socher was ho croated Ghas his work was givon hine He was to ISnd arployzent and happlnees in tandire the thines that cod bad crosted; and In

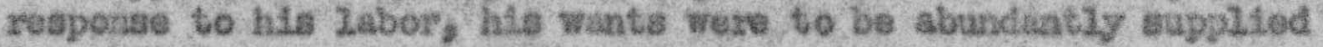
from the frutte of the Cartian of sden.

Whlle our Ilrst parvnte obeyed Cod, thair labor in the carden was a pleasures ard the earth rleldod of its abuadance for thelr wants. Dat when man departed frou obedience, he was doonde to wrestlo with the soede of Satan's sorring, and to earn his bread by the sweat of his brow. Henceforth he sast battle in toll and bardship againat the powes to which he bed yleided his will.

It was Cod's parpose to alleviate by toll the evil brought Into the world by $\tan$ 's disebedlenoe. By toli the tenptations of Satan might be bade Inefreotwel, and the tide of evil stayod, And though sttenced with anxiety, weariness, and pain, lsbor lo atili a sourse of heppiness and deveiograent, end a safoguard agatnet tengtation. Ths discipline pleces a check on self-Indulgonce, and proistes indus6ry, purtty, and Itreness, Thus it becotise a pert of Ood's great plan for ois recovery froa the fasl. 2

The way that they have been conducted at the eolloge does not bear the lapress of heaves, It does not etrongthen the Latelioet. It does not refine and purify the chanacter. Fhore are throscle Loading out through the habits and cuotong and worlely praotlecs, and the actors becose so cagroseed and Infatuated that they are pronouneed in heaven 20 vors of pleature nore than lovers of God, In the place of the intellect becontig strongtbened to do bettor work at otudents, to be betrez cualsried as Christlane to perfora the Cirlstian Auties, the ozersise in these gases is filling thalr braine with thoughts that diotrsot the radid fron their studtes. . . .

1.uen C. White, Patrlarchs and Prophets, p. 602,602.

${ }^{2}$ walen a. White, coumedis to Teachers, pp. 273,274. 
Is the eye sinq2e to the glory of Cod in these ganes? I lanow that this is not so. there is a loeting sidht of Cod's way and 17 se

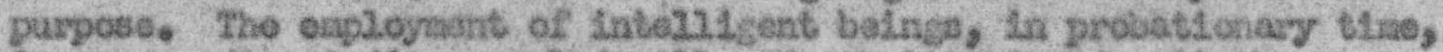
Is euperseding Codte stovoaled w131 and substituting for it the speculstioas and liventLons of the haman agent, whth Satan by his

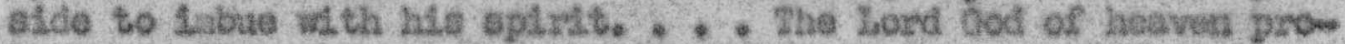
tosts agsinst the buming pesgion ouztivated for suproaucy in the gawoe that are so engrossing 3

Let the youth who noed an eduestlon sot to wosth whth a deterratnation to obtain $1 t_{\text {p }}$, Do nob ralt for an oponingy nuloe one for yourselvos. Take hold in bny shall way that probents iteete.

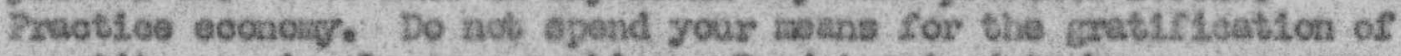
appetite, or in plessuro eeeldig. Be deternined to becono se useris and efrtetent as clod calle you to be. Be thorcesth and falthrus In whatever you undertakio. Frodure every advantage within your rasch foz strengthering the intollect. 4

Christ was the andy atinless one who ever duelt on earthy yot for nosziy thirty yoars to 24wed asoag the wioked Lahabitants of Iasaroth. Thie fact is a robulie to those whe think thenevives dopendent upon place, fortune, oz prosperity, in order to live a blanaless 14fo. Senptation, poverty, advorsity, is the very elselplino needed to develop purity and striatese.

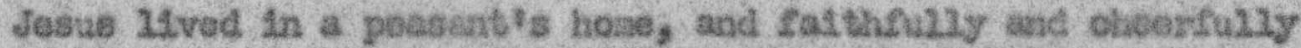

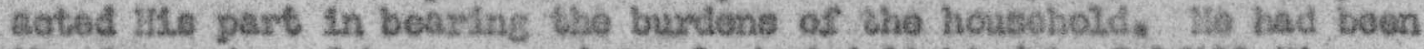
tho Combander of hesvon, and angels had delighted to fusctu Hia worts now lle was a winling sezvant, a loving, olediest achs lie learned a trade, and sibh his cun hands workad in the carponterts Ehop with Joseph. In the slinple garb of a counon Jaboros lio walleed

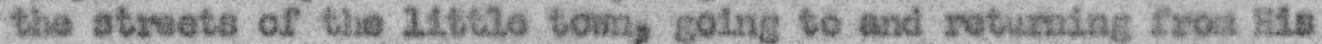

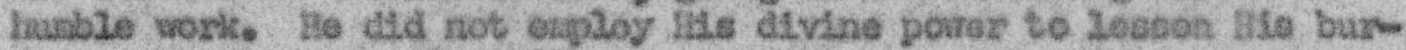
dens or to 14ghton Ris toll.

As Jesus worked in elilalsood and youth, raind and body wers doveloped. He did not use hie shystcal porests reoklessiy, but in such a way as to koep thea in bealth, that tie alght do tho best work in every 1ine. Ile was not willing to be defoetive, even in the handuine of tools. lle was perfeot as a workinan, as lie was porfect in charseter.

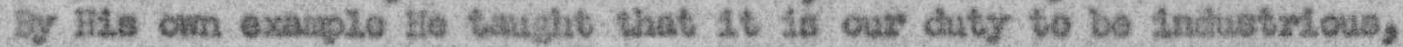
that our work elocuzd bo parfoned with exaetress and thorouglmess,

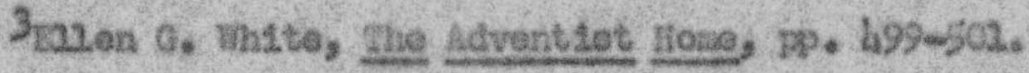

Halen 0. Thite, Gardetle Gleat Lessons, D. 334. 


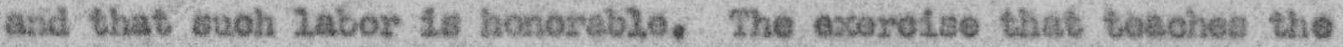
hande to be useful and treine the young to bear thefr share of 2ife's burdens glvos plysieal strencth, and dovelops every faculty. A21 should find soasthing to do that will bo bonollelal to thensolves and helpful to othere. Cod appointed rork as a blesstag, and oniy. the duligont worker finde the true glory and joy of life. The epproval of cod rests with loving assurance upon childiven ard youth who cheersuliy take thelr purt in the duties of the houschold, aharIng the burdens of fathor and mothor. Sugh ehildran will, no out from the howe to be userul seribers of soclety. 5

T1us is too short now to accoiplish that whioh night hew boen dene in past generatl.che. Dut evor in these last daye we can do zach to correot the extating ev12s in the eduostion of prouth, And because tine is short, we shonle be in eamest, and work scalously to give the young en education conslatent with our fatthe He are reformere* We desire that our chlldren should ettdy to the best divantage. In order to to chis, employnent should be glves then

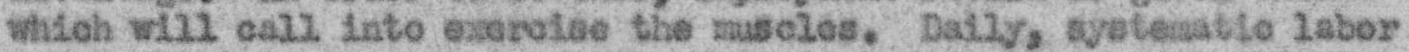
should constitute a part of the edication of youth oven at this late portod. Whah can now be grinod in this way. In folioning thise plan the studente will realige clastlekty of spirtt, and vigor of thought, and in a etven tine can aceorplswh sore mental Leibor than they eould by study alone. And thus they oan 2esve sekool wi.th conetilutione urliapalrod, and with strength and eouruge to peroevere in any postiton where the providence of God may place thas,

The exerolse that teschen the hand to be userul, and tratine the

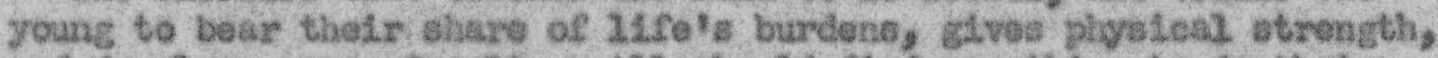
and dovelops every faculty. A21 should PInd sossthing to do that will be benefteial to thersalves and holpiul to others. God appointed

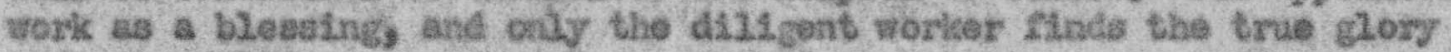
and joy of 1 ife.

Bradn and mastele mast be taxad proportlonately, if havith and vigor are to be malntelned. The youth ean them bring to the otudy of the word of Ood healty pereeption and well-balanced nomves, Thoy w11. have wholeagae thougtats, and can retatn the proolotse thirges that are brought froa the word, They rill disest 1 ts truthe, and as a reosit w112 havo braln-power to dlscem what is truthe phen, as oceaston derancis, they ean glve to overy ban thaf chise a reasch of the hope that ie 1 in then with mesicress and fosm.

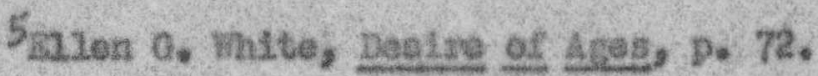

$$
\begin{aligned}
& \text { 6nim G. White, Jestincnies to Uhe Chureh, Vol. 6y PD. 279,280. }
\end{aligned}
$$


Such tratning w112 make tho youth sasters and not slaves of $1 \mathrm{abor}$. It w112 11 ghten the lot of the hard toller, and will ennoble even the hunblest occupatien. He who regarde wortc as nore drudpery, and settles dons to $1 t$ with seli-complacent 1.gnorance, naklng no effort to lingrove, w112 find it lndeed a burder. But those tho rocognise volence in the humblest work w113 see in $1 t$ noblitty aad beauty, and nit3i take pleasure in performing it wi th faithrutnoss and offiolenoy.?

I have been forvibly Inprossed with the faot that tralning to productive Inclustry droothy tenda to develop sound Judgesnt and maniy independence-those qualities of the mind and beart that colLeotively constitute the character of the educated sen. * * Their work in tho shop and on the fara had brought thea - into touch with real issues and real thincs, . . 1t had taught thess to thithe,

In the perforrance of these dutles, eareless, neclectral, disorderly habite should be overcores for unlese comected, those habite wili be carried Into every phase of Life, and the Lffo wili be spolied for uselulness, spolled for true missionsyy woric, Uriless corrocted with perseverance and resolvilon, they will overcens the etudent, for tiree and eternity. The youns should be enceuraged to form correet habits in droes, that tielr appoarance say be neat and attreotive; they should be taught to keop thesr garaonte clean and noatly mended. AII thair habits should be such as to malke then a holp and a confort to others?

I cannot IInd an Aristance In the 21fe of Christ where He devoted time to play and anuesment. Lie nus the groat edueator for the present and the future lifes yet I have not been able to find one instance where He taught the disglples to engace in arusenent in order to galn phyeical exerotse, 10

In the erootion of schoolubalidings, in thelr furriahing, and In every feature of thelr mangement, the strictest econow ast bo praotsced. Our sohools are not to be eondueted on any narror ox colrtsh plans. They eiould be as horalilco as poestble, and in every Leature they are to teach correct lessons of almplichty, usefuiness, thrirt, and econours.

7azen G. White, Sucatlon, p. 222 .

Bgooker I. Waahington, Working With the Hands, $\mathrm{D}_{6} 63$.

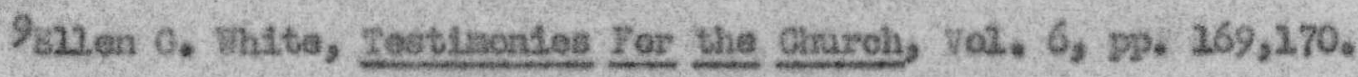

10 Hien 0. White, Gounsels to Teachers, p. 309. 
Hot only for the flnanelal welfare of the scheols, bat 21 le as an education to the students, econory should be falthfualy etudied and consclentiously and d121geatly practeed. Tho ranageri nast guard carefuliy overy polith, that there way be no neodlese expense, to bring a burian of dabt upon the school. svery atudent who loves Cod suprenely w111 help to bear the roeponstbiltiy in this iatter. Those who havo lech edueated to do this, car denonatrste by precept and exanple to those with whor they cone in contset, the prinelples taught by our seli-lenglus pedeener. Solf-indulgence is a creat evil, and rast be ovarcone, 21

11.11en 0. White, Festisaries For the Oharoh, Vol, 6, po 20\%, 
APPBUDTK 3

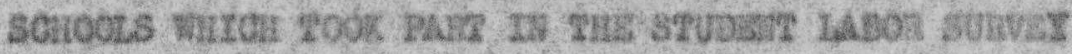

\author{
Axwona Unton Mcadery \\ Dattle Creak Acadery \\ Q2uo LeuntaIn Acsdery \\ Broadview hasdery \\ Cangtoa houdeny \\ Caradtan Undon Oollege Aebdery \\ Coday Ialce Aodiery \\ Collogedale Acedery \\ Colmbia sondeny \\ Emanuel wiovLonazy Col2ege Acacexy \\ ELtoher Acadary \\ Forest Lake hoadeny \\ Trosho Dhion Adactery \\ Cartan skate Meadenty \\ Gea Btale Acadony \\ Clendsle tralon Aesdery \\ Czand Ladge Lesdery

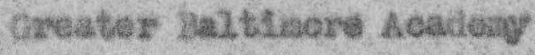 \\ Crester Busten Acedeny \\ Groater Man Zork Aoadony. \\ MLthend Asademy
}

Tndiana Aoacteury

La bierra Proparktory School.

Lsttio Creal headery

Lod1 Acadery

Losis IInds Unton Acstery

Inzerod Acadey

Haplenood Acadery

W20 Acadory

Kodesto Unton Aoacisey

Hontersy Pay Aceide:y

Wt. Aetas hoadeny

Ht. Plagah Aceilery

Lountatn VIew Luton Asadery

Newbury Park Actidery

Osk Park Acadery

Oshara Acedory

Pachezo Untod Collece Rrep. Sahool

PIne Forgo hexieny

PLetrvies Aodedery

Ratie Vauley acedery

Portiand inlon deadery 
San Blogo Acadery

Ben Pagqual Aeadery

Bheyenne River Acadery

Bouth Iancaster Acadesy

Southrestern JunLon College Lcadery

Surnyriale Acadary
Takosas Acadery

Unton College Acedery

Union Springs Acadony

Valley Granilo Acadony

wiscorsin Acalery 


\section{Apandix 6}

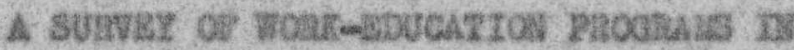

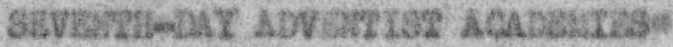 \\ Roluart A. Tyson}

In ordar for education to train the tolal porecaalitys ste is

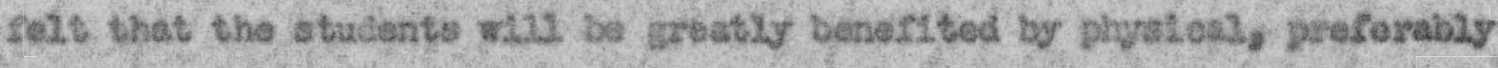
cultioor, work. In tha formastive alolescent yodrs tho student stould

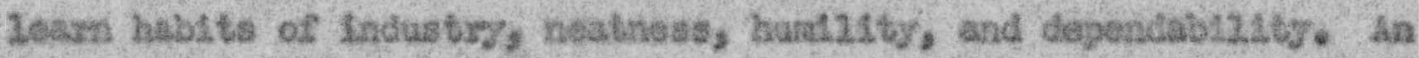

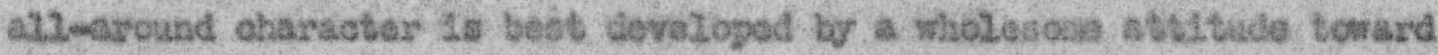

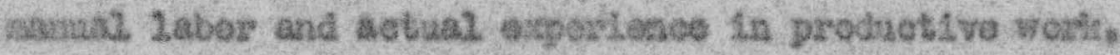

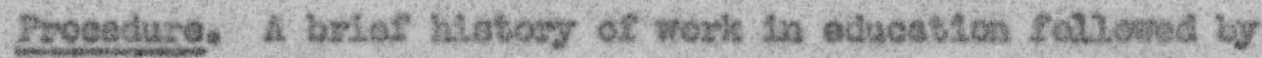
rolated 1iteratire, experinents, and projesta in son-Seventh-elay Advoatist Behoole in tho Undted Stalca opaned the otudy.

The Sevanth-day kdventlet phdlosoply of balanced education was

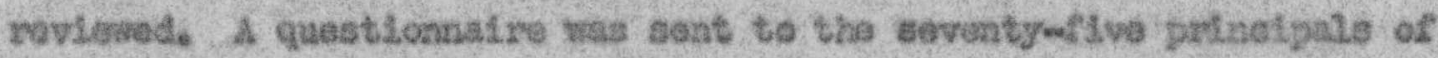

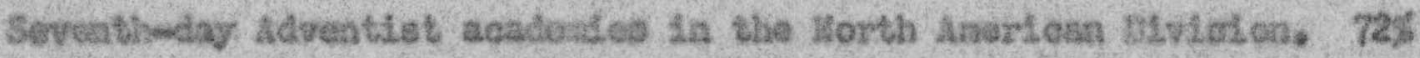
of thea enswerod in tive to have thoir sehools enter Into the survey. Thastywseven graphs and flrunus tabulate the rosults of roseareb in

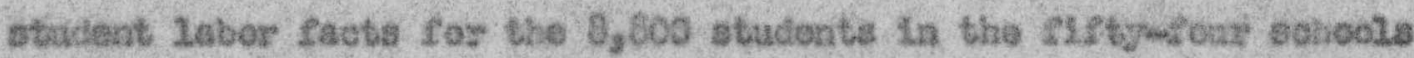
sarvoyod.

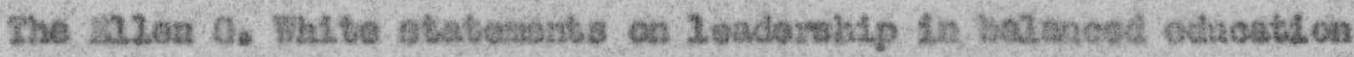

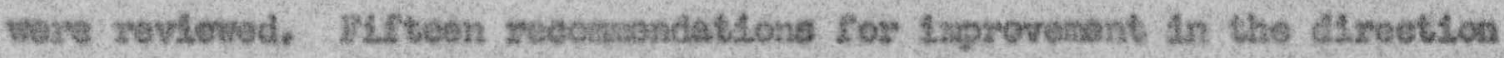
Jane 1959.

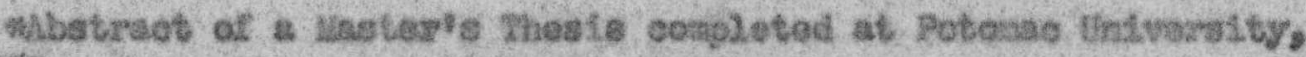

